المؤتمر العلمي الدولي الثالث للعلوم اللغوية والأدبية

II. ULUSLARARASI DIL VEBDBBIYAT KONGRESI

كتاب وقائع المؤتمر

Tam Metin Kitabi

Full Text Book

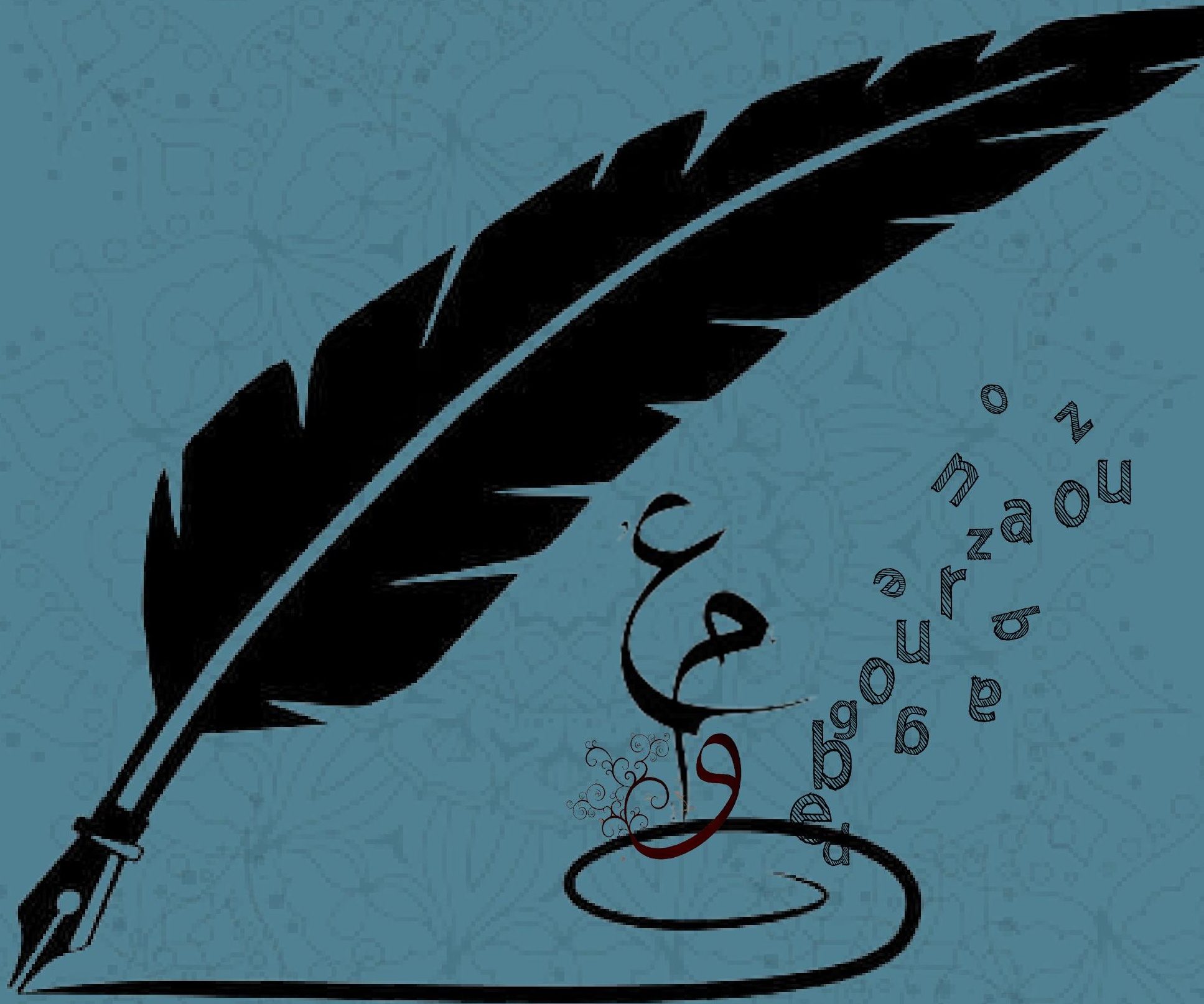

RIMAR ACADEMY

Publishing House 
III. International Congress of Language and Literature

III. Uluslararası Dil ve Edebiyat Kongresi

المؤتمر العلمي الدولي الثالث للعلوم اللغوية والأدبية

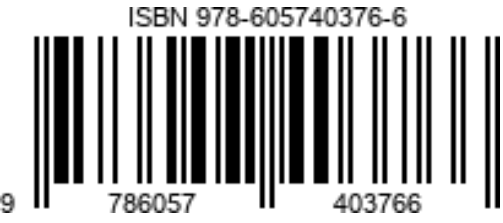




\section{Editör (المحرر)}

Prof. Dr. Enver TÖRE

Hazırlayan (إعداد)

Rimar Academy- أكاديمية ريمار

Yayın Koordinatörü (منسق النشر)

Emel KAPLAN

ISBN:

978-605-74037-6-6

kongre Tarihi (تاريخ المؤتمر)

2021 (Novmber) 16-17 تشرين الثاني

Baskı (تاريخ الطباعة)

2021 (December) كانون الأول

Matbaa Sertifikası No (رقم شهادة المطبعة)

47843

Copyright ( $)$ Published by Rimar Academy Publishing House 


\section{ÖN SÖZ}

Rimar Academy ile Iğdır Üniversitesi arasında 16-17 Kasım 2021 tarihlerinde yapılan “III. Uluslararası Dil ve Edebiyat Kongeresi” (International Language and Literature Congress) kurum ve kuruluşların kararlı işbirliğinin, çalışmalarının, maddi ve manevi katkılarının sonucunda gerçekleştirilmiştir.

Rimar Academy Türk dünyasının farklı akademik çalışmalarını ortak bir zeminde buluşturmaktadır. Bilim dünyasının değerli insanlarını farklı çevrelere ilişkin; eğitim, edebi, kültürel, sosyal, siyasi, ekonomi ve diğer konulardaki gelişme düzeyinin artırılmasına, ikili ya da bölgesel sorunların çözümüne dair alternatiflerin sunulmasına yönelik bilimsel çalışmaları paylaşmak kongrenin asıl amaçlarından biridir. Rimar Academy Kongre Bildiri Kitabı, bilimsel üretimin geleceğe birikim ve katkı olarak aktarılması hedefiyle hazırlanmıştır.

Bu kongreye yurtdışı ve yurtiçinde olmak üzere toplamda 141 kişi başvurmuştur. 71 bildirin bilim kurulu tarafından kabul edildiği; kabul edilen bildirilerin 8'i Türkiye'den, 63'ü Türkiye dışından katılım sağlamıştır. Kongreye katılanların 6'sı tam metin olarak, kalan diğer makaleler Ijjher Journal dergisinde yayımlanmaya uygun görülmüştür. Virüs sebebiyle 19 katılımcı yüz yüze, 52 katılımcı online olarak kongreye katılmıştır.

Kongremize değerli katkılarından dolayı tüm bilim insanlarına, teşekkür ediyor ve saygılarımı sunuyorum.

Prof. Dr. Enver TÖRE

Editör 


\section{KATILIM SAĞLAYAN ÜLKELERIN DAĞILIMI}

International Language and Literature Congress (3)

15

10

5
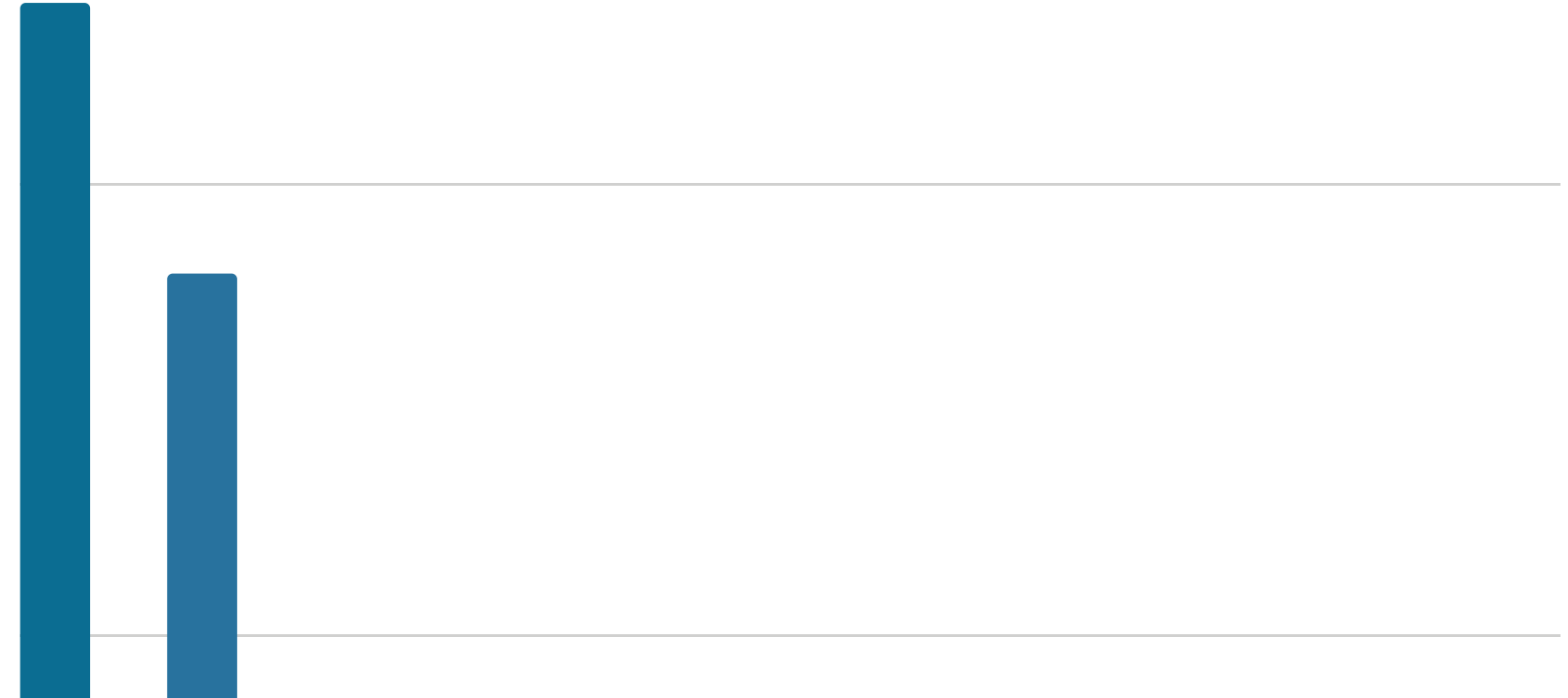

0

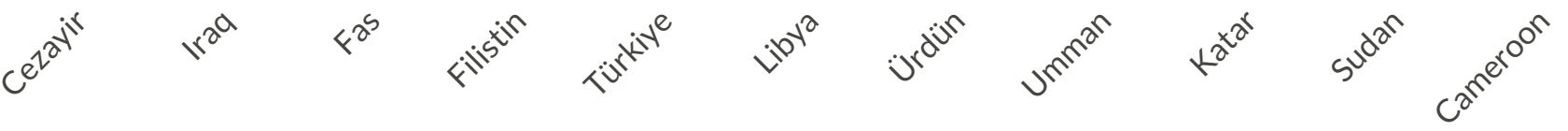




\section{KONGRENIN PROGRAMI}

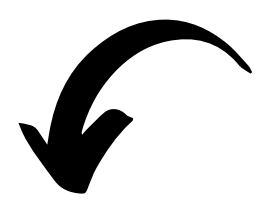

https://bit.ly/3FFdZ6W 

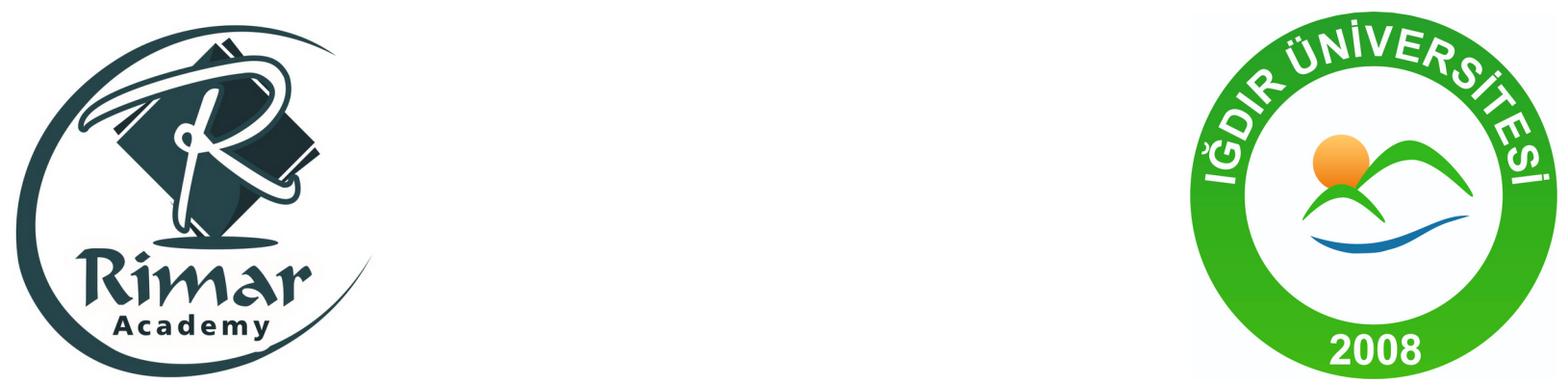

\section{bildiki kitabi}

16-17 KASIM 2021

Istambull = Turkey
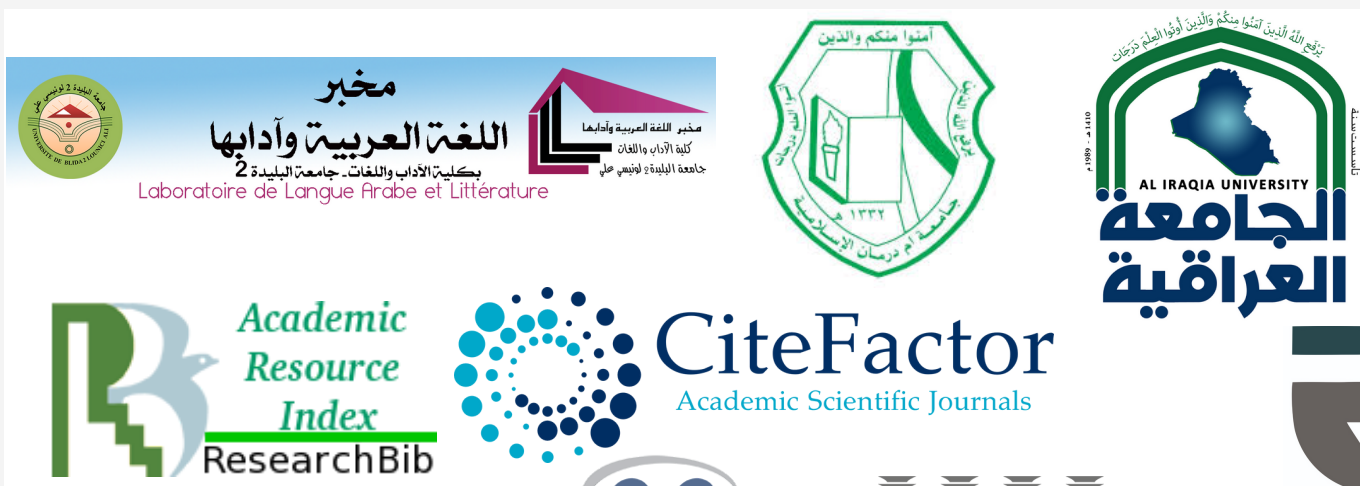

Academic Index

ResearchBib
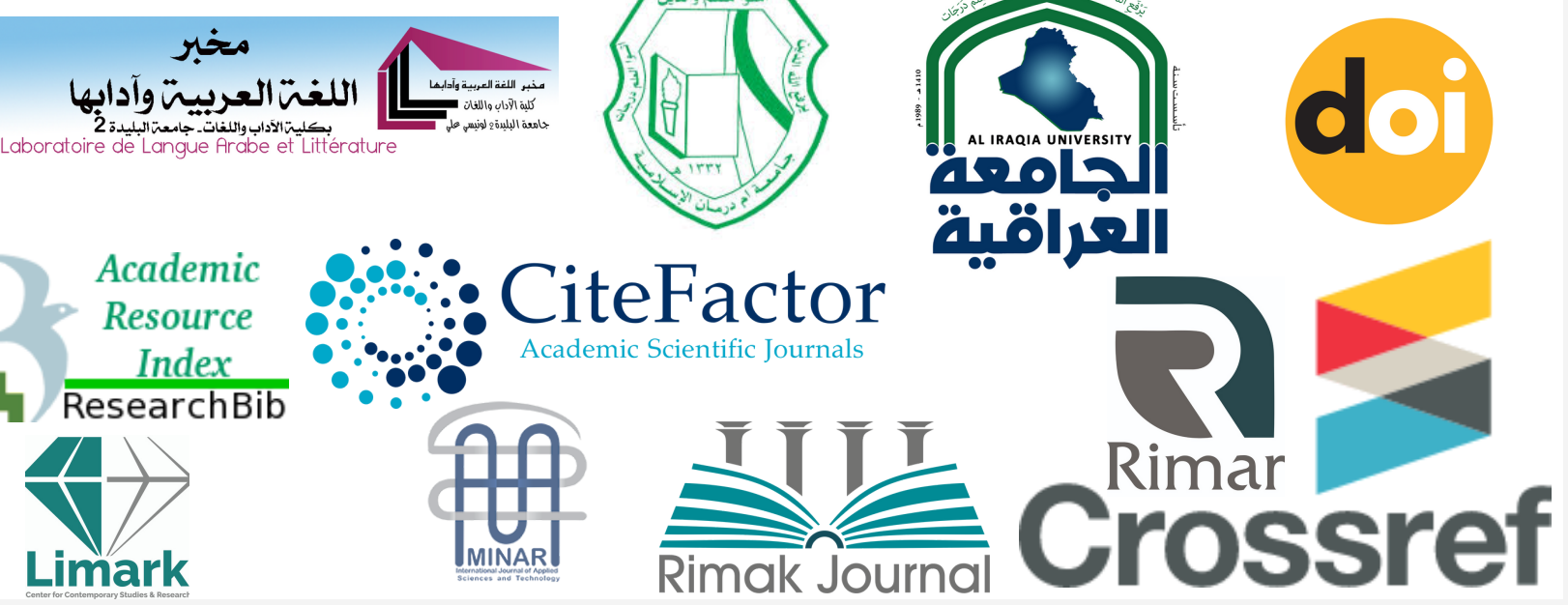


\section{Hakem Kurulu}

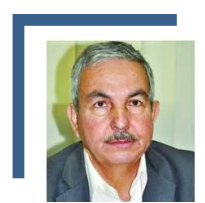

Prof. Dr. Salah Belaid

President of the Supreme Council for the Arabic Language

Algeria

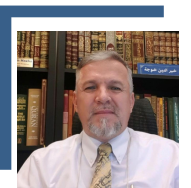

Prof. Dr. Hajredin HOXHA

Rimar Academy

Kosova

Prof. Dr. Khalil-M-H-ODEH

An Najah National University

Palastine

Prof. Dr.Yacine BENABID

Mohamed Lamin Debaghin University

Algeria

Prof. Dr. Mahmood Fawzi Abdullah ALKUBAISY

Aliraqia University

Iraq
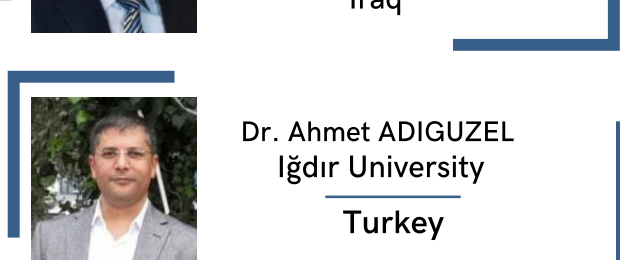

Dr. Ahmet ADIGUZEL Iğdır University

Turkey

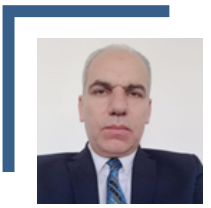

Dr. Bekir Mehmet ALI

Kilis7 Aralık University

Turkey
Prof. Dr. Ali Salih HUSSEIN

Rector of Aliraqia University

$$
\text { Iraq }
$$

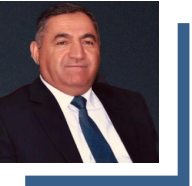

Prof. Dr. Muhtar KAZIMOĞLU

Director of National Academy

of Sciences Institute of Folklore

$\overline{\text { Azerbaijan }}$

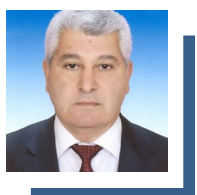

Yakın Doğu University

Cyprus

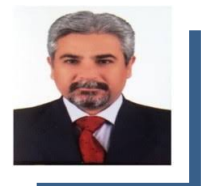

Dr. Nahidh Falih SULAIMAN

Diyala University

Iraq

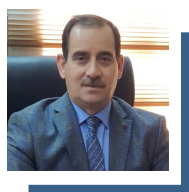

Prof. Dr. Luma IbrahimAl-BARZENJI Diyala University

Iraq
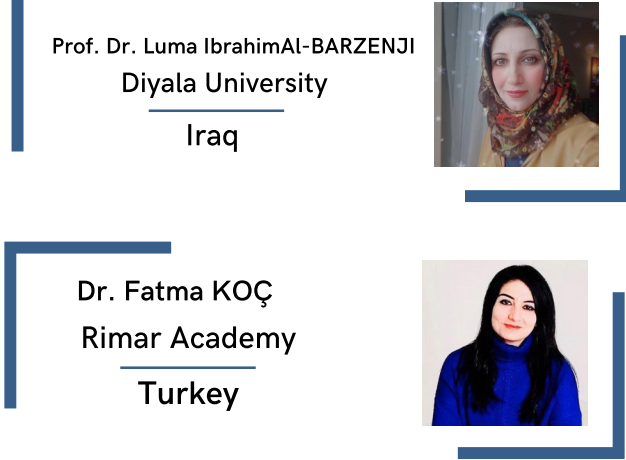

Dr. Osman TÜRK

Harran University

Turkey

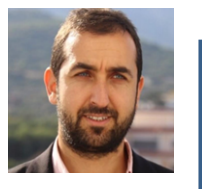




\section{Hakem Kurulu}

Prof. Dr. Faeza Abdulameer Nayyef
Al HUDEEB
Baghdad University
Iraq

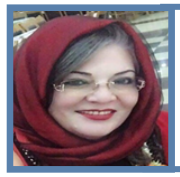

Prof. Dr. Azza Adnan Ahmed EZZAT

Zakho University

Iraq

Prof. Dr. Zaidoon Fadhil ABID
Unevircity of Anbar
iraq

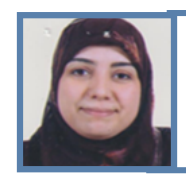

Dr. Djamila GHRIEB

Badji Mokhtar University

Algeria

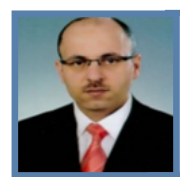

Dr. Yakup GÖçEMEN

Kilis 7 Aralık University Türkiye

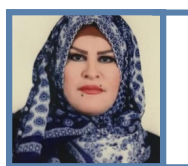

Dr. Bushra Ni'ma RASHID

Baghdad University Iraq

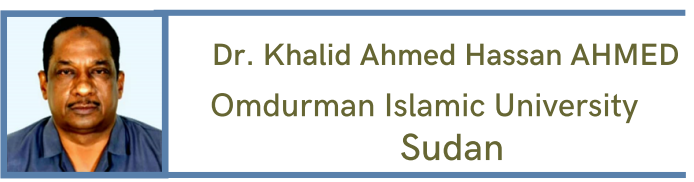

Dr. Mohamad TURKEY
Ankara University
Türkiye

Dr. Zakia MEHENNA
Abderrahmane Mira Bejaia University
Algeria

Dr. Salwa Jirjees SALMAN
Kirkuk University
Iraq
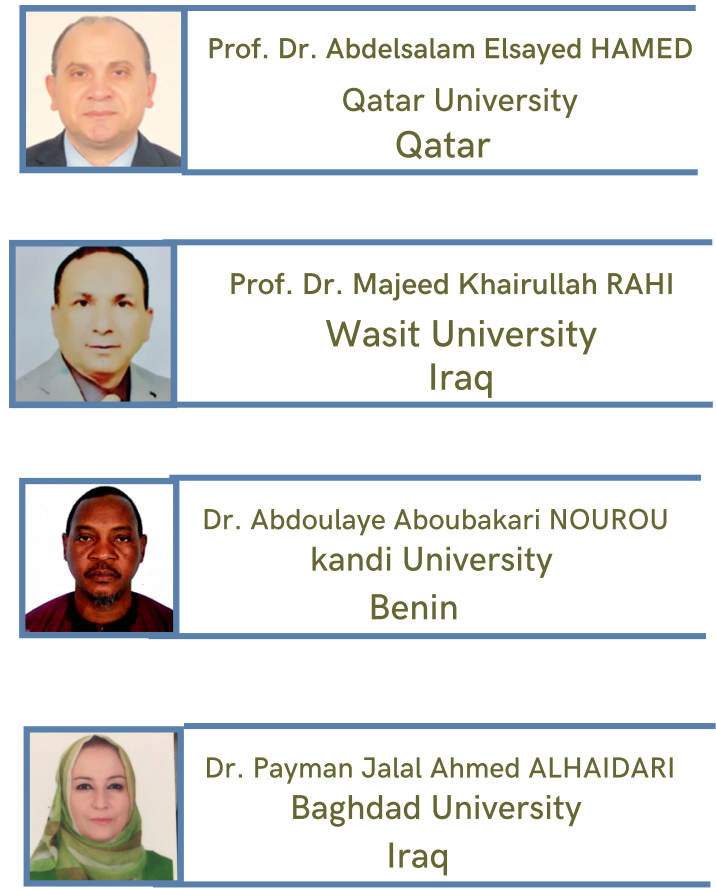

Dr. Gaafar YAYOUCH
Abdel Hamid Ibn Badis University
Algeria

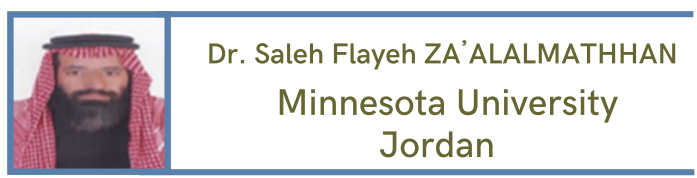

Dr. Mahmud KADDUM
Bartın University
Türkiye
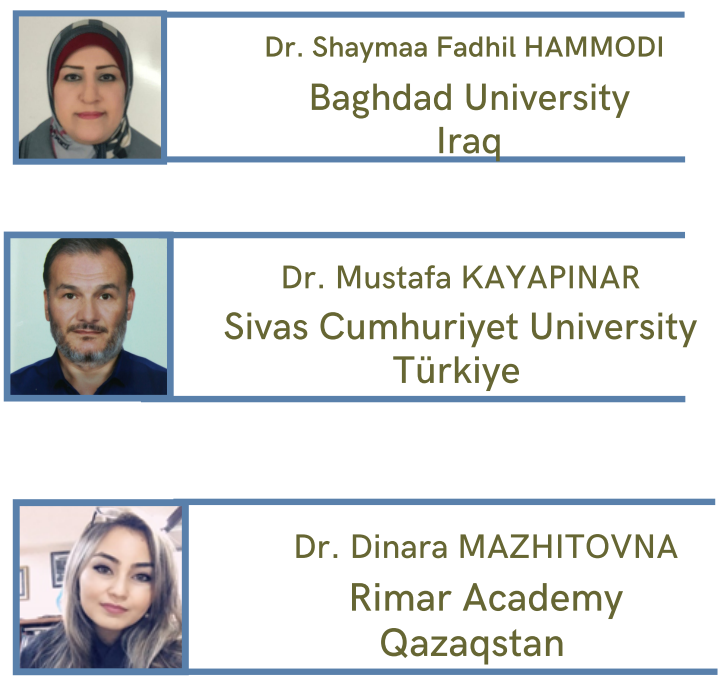


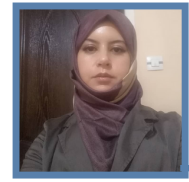

Dr. Ibtissem KHELLAF Blida2 University Algeria

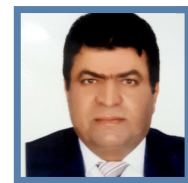

Dr. Aslam JANKIR

Mardin Artuklu University Türkiye
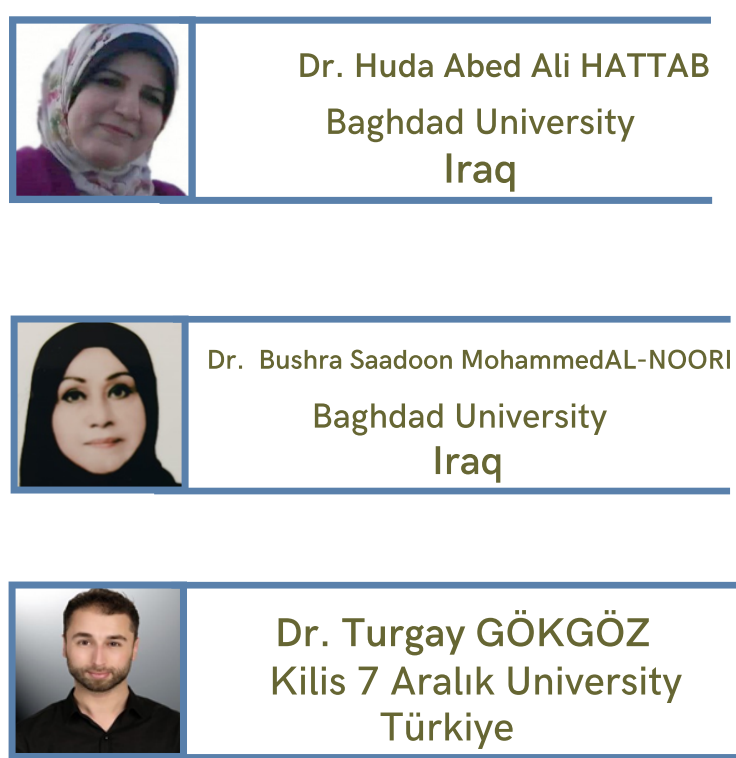

Dr. Turgay GÖKGÖZ

Kilis 7 Aralık University Türkiye
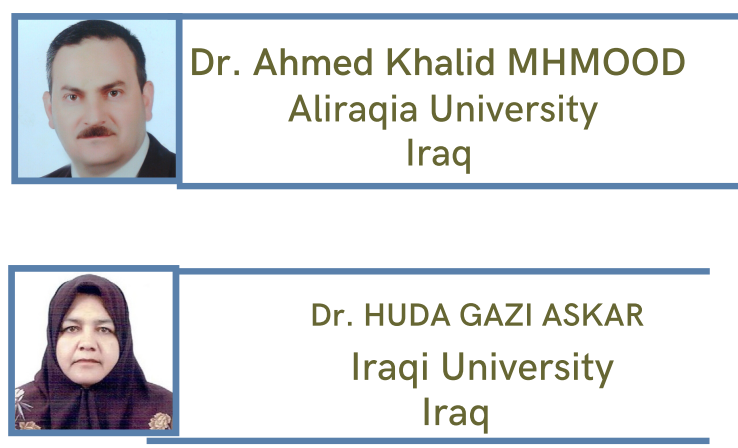

Dr. HUDA GAZI ASKAR

Iraqi University Iraq

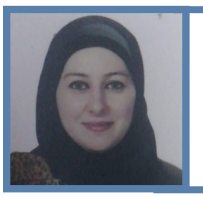

Dr. lamyaa Hussein ALI Baghdad University Iraq

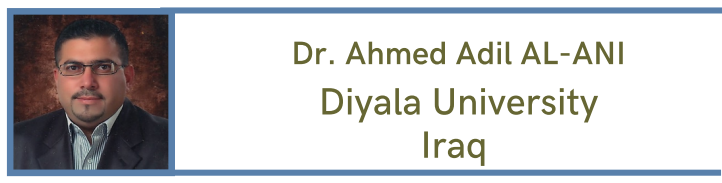

Dr. Bekir MEHMETALI
Kilis 7 Aralık University
Türkiye

Dr. Ibrahim Çeçen
Ağrı University
Türkiye

Dr. Hanaa Mahmood Ismael JANABI
Iraqi University
Iraq

Dr. Hüseyin ESVED
Bingöl University
Türkiye

Dr. Muhammed Murtaza ÇAVUŞ
Dokuz Eylül University
Türkiye

Dr. Amal AL ABDULLAH
Basrah University
Iraq

Dr. Ibrahim ALŞIBLi
Mardin Artuklu University
Türkiye

Dr. Ahmet KAYA
Harran University
Turkey

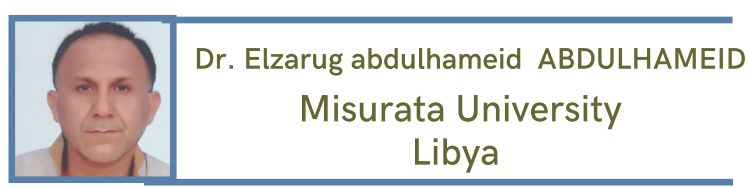




\begin{tabular}{|c|c|c|}
\hline \multicolumn{3}{|c|}{ الـفهرس//çindekiler / Table of contents } \\
\hline $\begin{array}{l}\text { Ahmet Turan } \\
\text { DOĞAN }\end{array}$ & $\begin{array}{l}\text { Teaching Turkish Orthography, Punctuation and } \\
\text { Dictionary Usage By Means of Internet Sources }\end{array}$ & P. $1-8$ \\
\hline Osman TÜRK & $\begin{array}{l}\text { AN EVALUATION ON THE "STORIES IN THE I. } \\
\text { Vol. OF MEVLANA'S MESNEVİ" }\end{array}$ & P. $9-17$ \\
\hline Levent BILGI & Ontological Theory In Literature & P. $18-22$ \\
\hline $\begin{array}{l}\text { Mehmet Emin } \\
\text { TUĞLUK }\end{array}$ & $\begin{array}{l}\text { A Competition to Find an Equal to The Twelve } \\
\text { Foreign Words Organized By The Şehbâl Magazine } \\
(1909-1914)\end{array}$ & P. 23-33 \\
\hline $\begin{array}{l}\text { Mustafa } \\
\text { KARABULUT }\end{array}$ & $\begin{array}{l}\text { An Investigation on Necip Fazil Kisakürek's Poems } \\
\text { Within The Context of Psychoanalytic Theory of } \\
\text { Literature }\end{array}$ & P. $34-42$ \\
\hline $\begin{array}{l}\text { Hasan } \\
\text { YURTBEKLER }\end{array}$ & $\begin{array}{l}\text { Two Authors in The Context of Socialist-Realistic } \\
\text { Literature: John Steinbeck and Orhan Kemal }\end{array}$ & P. 43-50 \\
\hline
\end{tabular}


TEACHING TURKISH ORTHOGRAPHY, PUNCTUATION AND DICTIONARY USAGE BY MEANS OF INTERNET SOURCES Ahmet Turan DOĞAN 


\title{
TEACHING TURKISH ORTHOGRAPHY, PUNCTUATION AND DICTIONARY USAGE BY MEANS OF INTERNET SOURCES
}

\begin{abstract}
Ahmet Turan DOĞAN ${ }^{1}$
Abstract:

The ways of accessing information are gradually changing although the source of information does not change much in the digital world we live in. In this context, printed works, which are seen as the most important source for accessing information, are increasingly being transferred to the digital world and the concept of e-books has become more common in the academic world. For this reason, it is important for students, teacher candidates and teachers in the relevant field to be educated about accessing and benefiting from related necessary online resources. Therefore, in this study, the subject of accessing and benefiting from online resources related to orthography, punctuation and dictionary usage which are among the most common subjects in Turkish was discussed. In addition, the place of orthography, punctuation and dictionary usage in both academic and daily lives, their importance as reference guide in the field and which online resources related to these subjects should be taken as a basis in the field were also explained. Thus, it is considered that this study will contribute to facilitating and accelerating the process of students', teacher candidates' and teachers' accessing to online resources which are seen as a necessity of the digital era.
\end{abstract}

Key words: Turkish, Orthography, Punctuation, Dictionary, Internet Resources.

http://dx.doi.org/10.47832/Lan.con3-1

- Bu çalışma, GAP Bölge Kalkınma İdaresi Başkanlığı destekleriyle 14.12.2020-14.12.2021 tarihleri arasında yürütülen “Dezavantajı Bölgelerdeki Eğitimcilerin Tekno-Pedagojik Becerilerini Artırma (BiLKAMPÜS)” başlıklı proje çerçevesinde hazırlanmıştır.

${ }^{1}$ Harran University, Türkiye, ahmetturanndogan@gmail.com, https://orcid.org/0000-0001-9173-7558 


\section{İNTERNET KAYNAKLARIYLA TÜRKÇE YAZIM, NOKTALAMA VE SÖZLÜK KULLANIMI ÖĞRETIMİ}

Öz:

İçinde yaşadığımız dijital dünyada bilginin kaynağı pek değişmese de bilgiye ulaşma yolları giderek değişmektedir. Bu çerçevede bilgiye ulaşmak için en önemli kaynak olarak görülen basılı eserler giderek internet ortamına taşınmakta ve artık e-kitap kavramı akademik dünyada daha fazla yer kaplamaya başlamaktadır. Bu sebeple, ilgililerin internet ortamındaki söz konusu kaynaklara ulaşma ve bu kaynaklardan yararlanma konusunda bir öğretime tabi tutulması önem arz etmektedir. Dolayısıyla, bu çalışmada Türkçenin en fazla başvurulan konularından olan yazım, noktalama ve sözlük konularına internet kaynakları üzerinden ulaşma ve bunlardan faydalanma konusu ele alınmıștır. Bunun yanında yazım, noktalama ve sözlük alanlarının akademik ve günlük hayattaki yeri, bunların başucu kaynağı olarak değerleri, bu konularda hangi internet kaynaklarının esas alınması gerektiği gibi konulara da açıklık getirilmeye çalışılmıştır. Böylelikle, bu çalışma ilgili alanındaki öğretmenlerin, öğretmen adaylarının ve öğrencilerin çağımızın gerektirdiği internet kaynaklarına ulaşmasını kolaylaştırma ve hızlandırma konusunda katkıda bulunacağı düşünülmektedir.

Anahtar Kelimeler: Türkçe, Yazım, Noktalama, Sözlük, İnternet Kaynakları.

\section{Giriş}

İnsanoğlunun en önemli icatlarından olan yazı bundan önceki yüzyıllarda olduğu gibi 21 . yüzyılda da önemini devam ettirmektedir. Bu hâliyle yazı, bilgi aktarımı için insanlığın en önemli araçlarındandır. Yüzyıllar içinde yazının önemi azalmasa da bilgi için yazılı metinlere ulaşmada kullanılan yöntemler mevcut teknolojik gelişmişliğe göre değişmektedir. Polat (2017)’ın da belirttiği gibi teknolojik gelişimler, bilginin kaydedilmesi, ulaşılması ve paylaşılmasına dair işlemlerin kolay ve hızlı yapılmasına katkıda bulunmaktadır. Dolayısıyla, teknoloji ilerledikçe ulaşılan bilgi oranı artarken bu bilgiye ulaşma süresi kısalmaktadır. Araştırmacılara ve öğrencilere bu imkânı sunan ise 21. yüzyılın dijital dünyasıdır.

E-kitaplar, e-dergiler, uygulamalar ve çeşitli internet kaynakları günümüzde bilgiye ulaşmak için en çok tercih edilen kaynaklar durumundadır. Özellikle internetin yaygınlaşması bu durumu beraberinde getirmiştir. TÜİK verilerine göre 2021 yılında 16-74 yaş arası internet kullanım oranı \%82,6'dır. Bunun yanında, hanelerin \%92'si de evden internete ulaşmaktadır. Ayrıca, internet kullanan bireylerin \%76,5'i hemen her gün interneti kullanmaktadır (TÜİK, 2021). Dijital 2021 raporuna göre \%63 ile internet kullanıcılarının çoğunluğu interneti bilgi edinmek için kullanmaktadır. Yine bu rapora göre internet erişiminin \%92,6'sı telefonla yapılmaktadır (We Are Social \& Hootsuite, 2021). Görüldügü üzere dünyada ve Türkiye'de internet kullanım oranı yüksektir. İnternet, çeşitli alanlarda çeşitli amaçlar için kullanılmaktadır. Çok büyük oranda telefon üzerinden insanların internete ulaştığı çağda bilgi edinmede telefon uygulamalarına da büyük iş düştüğü aşikârdır.

Bilgi edinme için kullanılan internet kaynaklarına baktığımızda kütüphane veri tabanları, derlemler, sözlükler ve indekslerin yer aldığı çeşitli veri tabanları, uygulamalar, e-kitaplar, esüreli yayınlar ve çeșitli internet siteleri yer almaktadır. Ancak, bu kaynakların büyük bir kısmının kitap, dergi gibi geleneksel bilgi kaynaklarının aksine yayımlanmadan önce içeriğinin onaylanması ve incelenmesi gibi bir zorunluluğu yoktur (Kurbanoğlu, 2002). Dolayısıyla bu 
kaynakları bilmenin yanında bu kadar çok kaynak içerisinde doğru ve güvenilir bilgi kaynağına ulaşmak ve ondan faydalanma yollarını bilmek de büyük önem arz etmektedir. Özellikle resmî kurumların ve güvenirliği onaylanmış kuruluşların internet kaynaklarından faydalanmak gerekmektedir. Bu durum Türkçe yazım, noktalama ve sözlük açısından düşünülürse yazım ve noktalama konusunda Türkiye'de tek yetkili kurumun Türk Dil Kurumu olduğu unutulmamalıdır. Türkçenin yazımı ve noktalaması bakımından bir birliktelik oluşturmak için bunun dışındaki kurum veya kişilerin kullanımları ölçüt olarak alınmamalıdır. Sözlük konusu ise çeşitli değerlendirmelere açık bir konudur. Türkçenin çeşitli dönemleri veya eserleri için yapılan sözlük çalışmaları bilimsel ölçütler çerçevesinde oluşturulduğu sürece kullanılabilir kaynaklardır. Bu konuda Türkiye Türkçesinin sözlüğünü hazırlamada resmî kurum olarak yine Türk Dil Kurumu öne çıkmaktadır. Ancak, bu konuda tek yetkili değildir. Hem Türkiye Türkçesinin hem de Türkçenin çeşitli dönem ve eserlerinin sözlüklerini alan uzmanı her kişi hazırlayabilmektedir. Dolayısıyla, internet kaynağı olarak alan uzmanı her kurum veya kişinin hazırladığı sözlükler faydalanılabilir durumdadır.

Doğru internet kaynağına ulaşmanın yanında ondan faydalanmanın yollarını öğrenmek için bir uzman desteğine de ihtiyaç duyulmaktadır. Özellikle günümüz dünyasında salgın şartlarıyla birlikte uzaktan eğitim, e-öğrenme gibi yolların sıklıkla uygulandığı göz önünde bulundurulursa bu alanın kullanım oranının gittikçe artacağı da öngörülebilir. Aynı zamanda eöğrenme, tüm iş gücü ve eğitim alanlarına uygulanabilirliği bakımından önemli bir avantaj sağlamaktadır (Harun, 2002). İnternet kaynakları üzerinden de Türkçe yazım, noktalama ve sözlük kullanımı öğretimi konusunda öğretime, dolayısıyla da bir uzman yardımına ihtiyaç duyulmaktadır. Aşağıda, Türkçe yazım, noktalama ve sözlük kullanımıyla ilgili internet üzerinden ulaşılabilecek kaynaklar açıklamalarıyla verilmiştir.

\section{Türkçe Yazım, Noktalama ve Sözlük Kullanımı Konularında İnternet Kaynakları ve Bunların Öğretimi}

Türkçe eğitimindeki temel konulardan biri de yazım ve noktalama öğretimidir. Buna özellikle eğitim seviyesi arttıkça ve Türkçe alanında ihtisas yaptıkça sözlük kullanımı da eklenmektedir. Dolayısıyla bunların öğretilmesi Türkçe eğitim-öğretimi açısında gereklidir. Öğrencilerin ve çeșitli araştırmacıların Türkçe yazım, noktalama ve sözlük kullanımı konularında faydalanabileceği internet kaynakları ve bunlardan faydalanma yolları şöyle siralanabilir:

\subsection{Türkçe Yazım Konusunda İnternet Kaynağı}

Bir dilin belli kurallarla yazıya geçirilmesine yazım denir (TDK, 2021). Türkiye'de yazım kurallarının belirlenmesinde ve bunun bir kılavuz ile yayımlanmasında yetkili olan kurum Türk Dil Kurumu'dur. Bu sebeple şu veya bu kurum, kişi tarafından hazırlanmış olan yazım kılavuzları TDK'nin hazırlamış olduğu yazım kılavuzunu esas almadığı sürece eğitimde, akademide veya resmiyette dikkate alınmaz.

Türk Dil Kurumu tarafindan hazırlanan kılavuzlar uzun zaman sadece basılı hâlde kalmıştır. Ancak, internetin yaygınlaşması ile Türk Dil Kurumunun internet sitesinden yazım kılavuzu içerisinde yer alan yazım bilgilerine ulaşmak mümkün olmuştur. Bugün https://www.tdk.gov.tr/kategori/icerik/yazim-kurallari/ adresinden yazım kurallarına ulaşılabilmektedir. 
Görüntü 1: Türk Dil Kurumunun İnternet Sayfasındaki Yazım Kuralları Giriş Sayfası
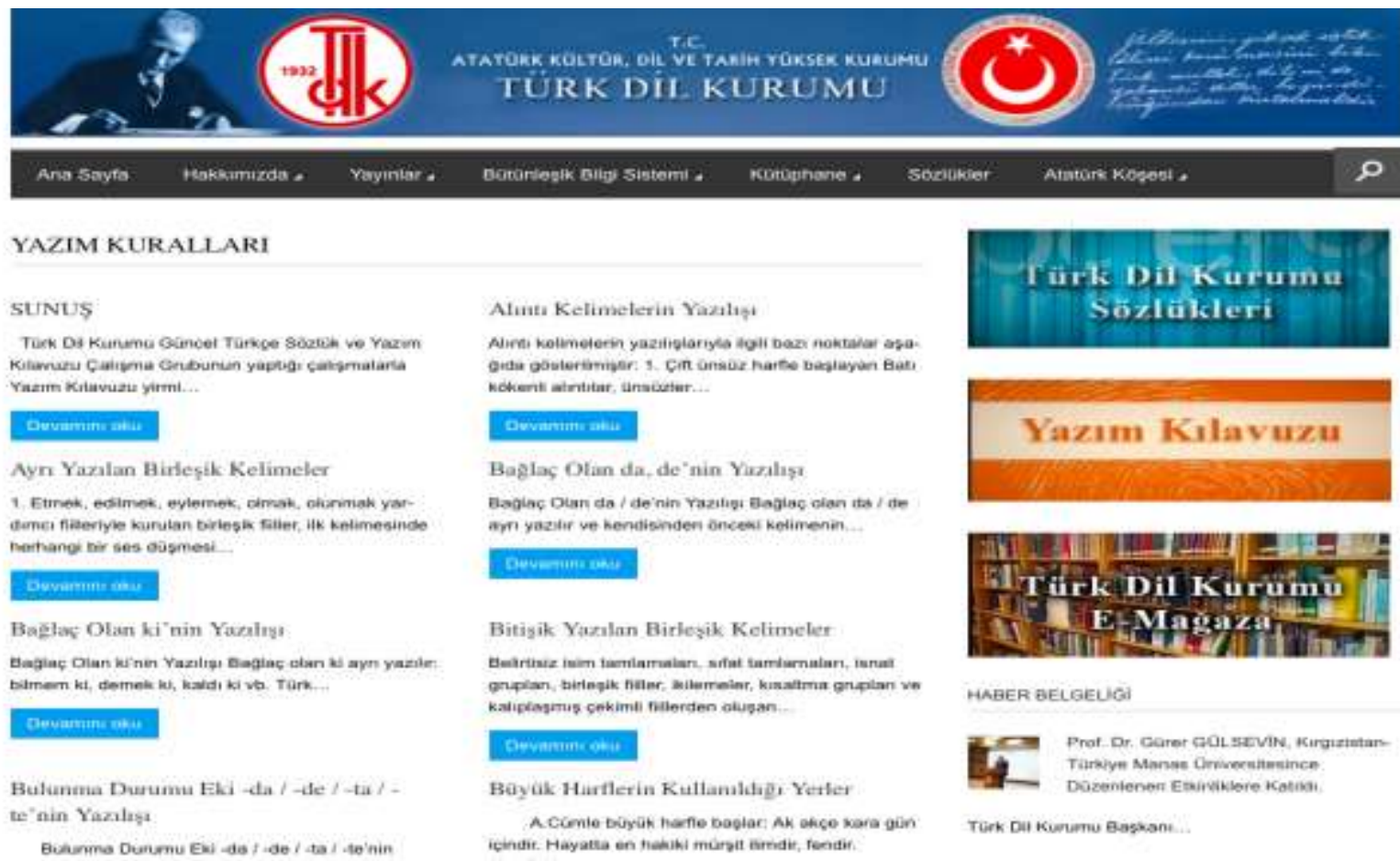

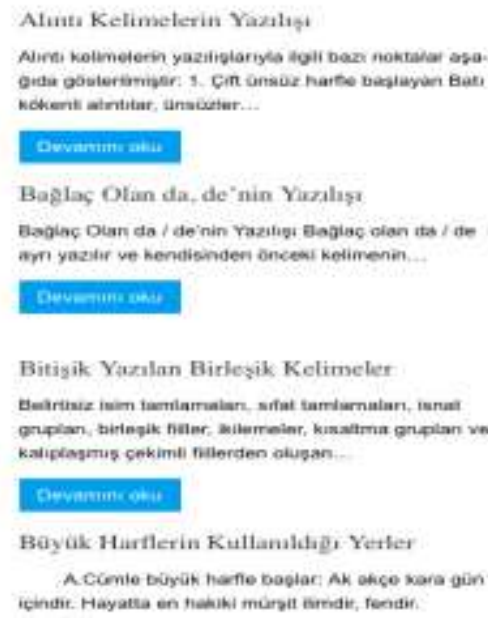

Afutu Kelimelerin Yazlą

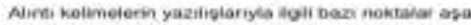

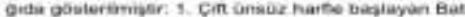
kokent atritiar, unacutur.

\section{Ovivamimatio}

Baglas Otin da, de'nin Yizralış

Eaglaç Dum da / de'nin razihy Eagiaç dian to / de am yazili ve hendisinden onceai ketimenin.

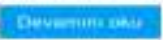

Bitisik Yaxalan Birlesik Kelimeler

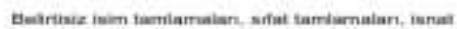

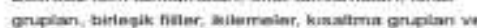

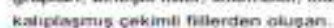

\section{Covaruincot:}

Boyok Hurflerin Kullanalage, Yertes

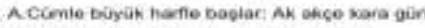

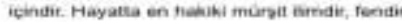
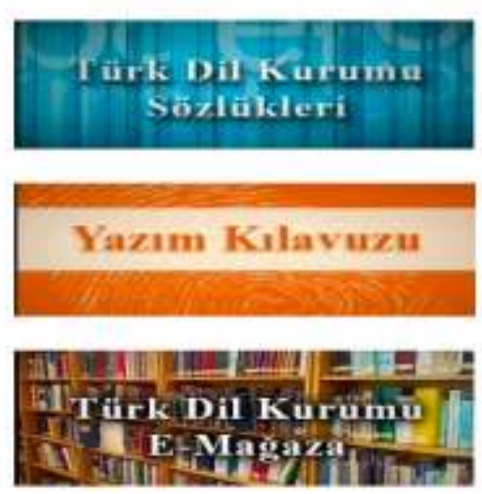

HARER BelGEUG:

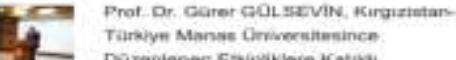
- Dozeniener Esaipaklore Kotio

Turk Dul Kunumu Baskane.

Görüntü 1'de yazım kurallarıyla ilgili giriș sayfası yer almaktadır. Toplam dört sekmesi bulunan yazım kuralları alanında birleşik kelimelerin yazımı, büyük harflerin kullanımı ve çeşitli eklerin yazımı gibi başlıklar ön plana çıkmaktadır. Bu başlıkların detaylarına "devamını oku" kısmına basarak ulaşmak mümkündür.

Yazım kılavuzu yanında TDK'nin internet sitesinde yer alan sözlük kısmında da arama yaparken çıkan yazım önerilerine bakarak da sözcüklerin yazımları konusunda bilgi sahibi olmak mümkündür.

\section{Görüntü 2: Güncel Türkçe Sözlük’te Yazım Önerileri}

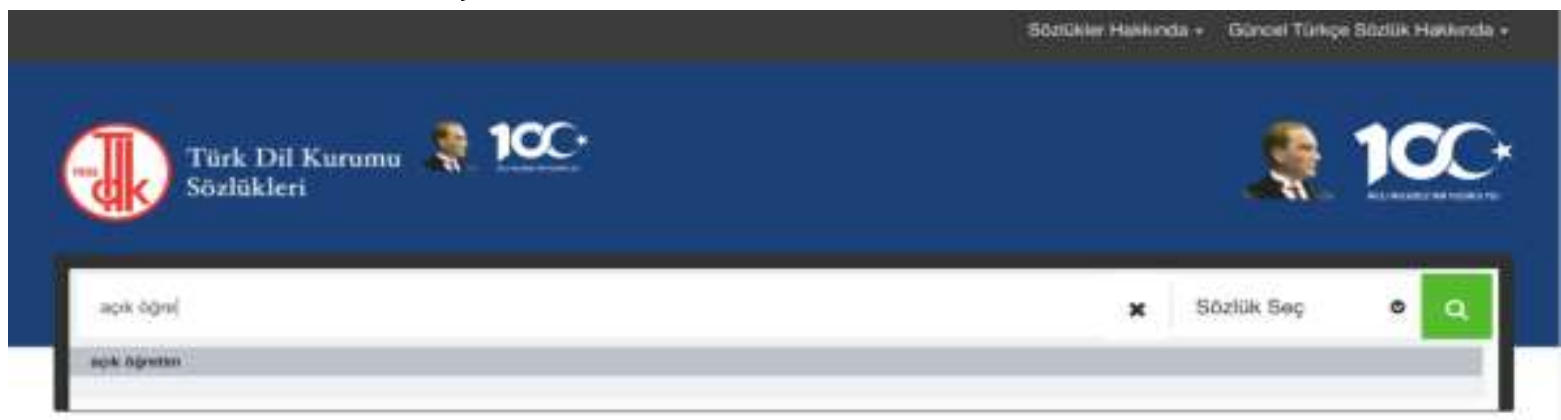

GONCEL TÜHKÇE SŌZL.OK

açık öğretim *1)

Dersleri nadyo, televizyon vb. araçarla yaymlanan veya posta ile ilgiliere ulasthilan egitim.

Görüntü 2'de görüldüğü üzere "açık öğretim” sözcüğünün yazımını Güncel Türkçe Sözlük'te aratıp yazıyı tamamlamadan çıkan öneriden sözcügün ayrı yazıldığını görmek mümkündür. Bunun gibi çeşitli sözcüklerin yazımını burada çıkan önerilerden görmek mümkündür. 


\subsection{Noktalama Konusunda İnternet Kaynağı}

Noktalama, bir yazının daha açık ve anlaşılır olmasını sağlamak için çeşitli işaretler kullanma işidir. Bu çerçevede kullanılan nokta, virgül, noktalı virgül, iki nokta, üç nokta, soru işareti, kesme işareti gibi işaretlere de noktalama işareti adı verilir. Noktalama işaretleri, konuşmadaki tonlamanın yazıdaki karşılıklarıdır. Onlar sayesinde anlam ayrımları oluşturmak mümkündür.

Yazım kurallarında olduğu gibi noktalama işaretlerinin kullanımını belirlemede de Türkiye'de tek yetkili kurum Türk Dil Kurumudur. Noktalama işaretleri ve kullanım özellikleri Türk Dil Kurumunda bir komisyon tarafından hazırlanan Yazım Kılavuzu içerisinde yer almaktadır. Basılı yazım kılavuzları içerisinde yer alan noktalama bilgilerine TDK'nin internet sayfasından ulaşmak mümkündür. Bunun için https://www.tdk.gov.tr/icerik/yazimkurallari/noktalama-isaretleri-aciklamalar/ adresi kullanılabilir.

Görüntü 3: Türk Dil Kurumunun İnternet Sayfasındaki Noktalama İşaretleri

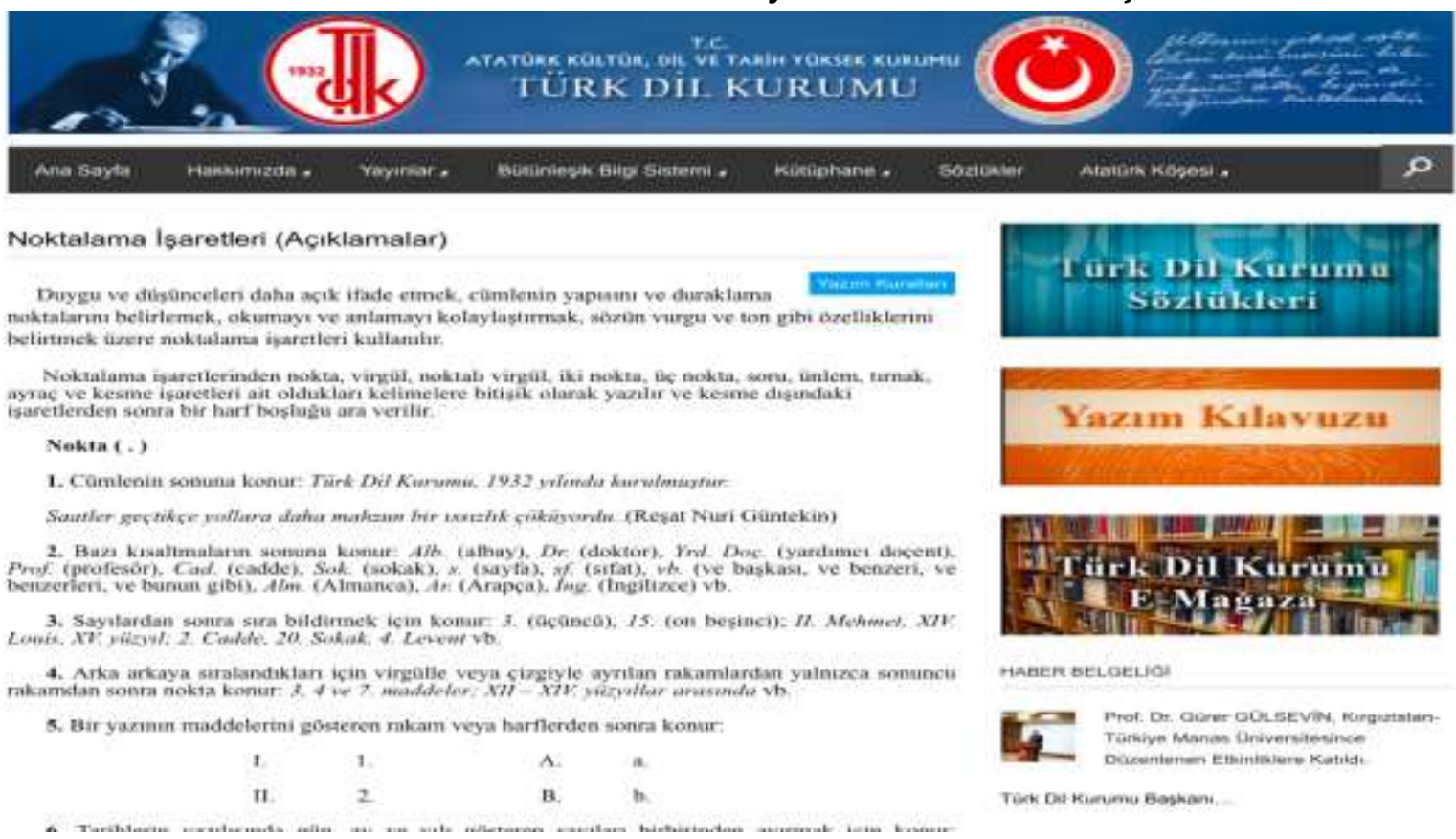

Görüntü 3'te küçük bir alanı görülen noktalama işaretleri kısmı tüm noktalama işaretlerini ve bunların açıklamalarıyla örneklerini içermektedir. Dolayısıyla bu kısımdan tüm noktalama işaretleriyle ilgili bilgileri edinmek veya uzaktan eğitim derslerinde ekrana yansıtmak için bu kısımdan faydalanmak mümkündür.

\subsection{Türkçe Sözlük Konusunda İnternet Kaynakları}

Sözlük, bir dilin bütün veya belli bir çağda kullanılmış kelime ve deyimlerini alfabe sırasına göre alarak tanımlarını yapan, açıklayan, başka dillerdeki karşılıklarını veren esere verilen addır (TDK, 2021). Türk dilinin herhangi bir dönemi veya eseriyle ilgili sözlük hazırlamak mümkündür. Yazım ve noktalama konularında olduğunun aksine sözlük konusunda tek yetkili kurum Türk Dil Kurumu değildir. Sözlük hazırlama ilkelerini bilen ve Türk dili uzmanı herkes sözlük hazırlayabilir. Bu sebeple Türk dilinin farklı dönemleri ve eserleri için hazırlanmış pek çok sözlük mevcuttur. Ancak, bu çalışmanın konusu itibarıyla internet kaynakları üzerinden ulaşılan sözlüklerin sayısı sınırlıdır. Bu konuda Türk Dil Kurumunun internet sayfasındaki ve telefon uygulamasındaki çeşitli sözlükler ön plana çıkmaktadır. TDK sözlükleri dışında çeşitli kişi veya kuruluşların hazırlamış olduğu sözlüklere de internet üzerinden ulaşmak mümkündür. 
Bunlara sırasıyla bakılacak olursa, ilk olarak TDK'nin internet sitesindeki sözlük karşımıza çıkar. Buraya şu adresten ulaşmak mümkündür: https://sozluk.gov.tr/

\section{Görüntü 4: TDK'nin İnternet Sitesindeki Sözlük}

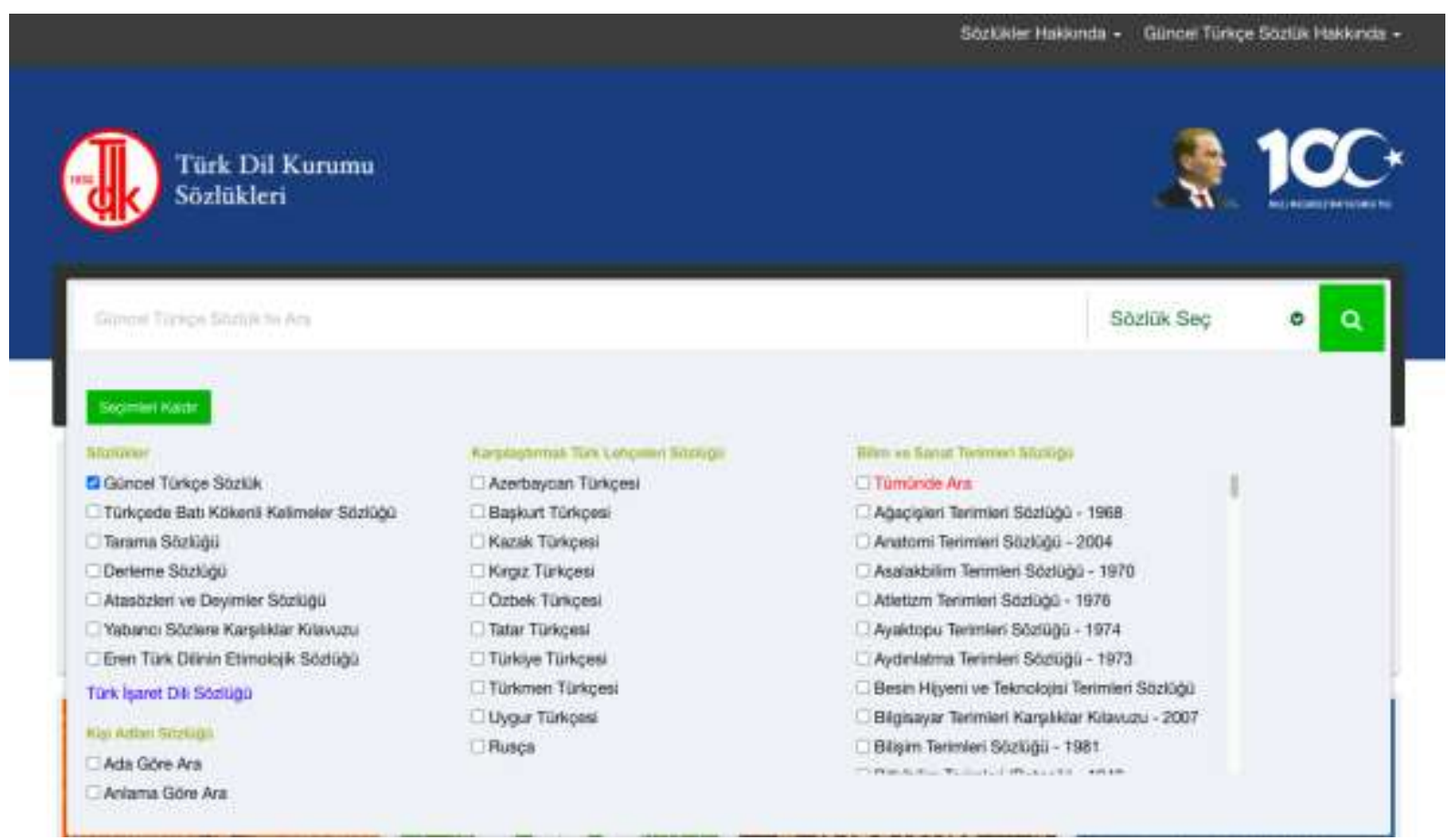

Görüntü 4'te görüldüğü üzere TDK'nin internet sayfasında yer alan sözlük kısmındaki "Sözlük Seç" kısmına basıldığında açılan yerde pek çok sözlük yer almaktadır. Buradan istenen sözlük seçilerek arama yapılabilmektedir. Bu kısma basılmadığında ise otomatik olarak "Güncel Türkçe Sözlük" üzerinden arama yapılmaktadır.

TDK'nin sözlüklerinin yanında Türk dilinin çeşitli dönemlerine ait sözlüklere de internet üzerinden ulaşmak mümkündür. Bu konuda tespit edilen güvenilir sözlük kaynakları olarak şunlar sıralanabilir:

1. http://www.tamga.org/2017/05/web-tabanl-gokturkce-sozluk.html (Türk dilinin Köktürkçe dönemiyle ilgili sözlük yer almaktadır.)

2. http://www.tamga.org/2019/06/web-tabanl-eski-uygurca-turkce-sozluk.html (Türk dilinin Eski Uygur Türkçesi dönemiyle ilgili sözlük yer almaktadır.)

3. https://www.osmanlicaturkce.com (Türk dilinin Osmanlı Türkçesi dönemiyle ilgili sözlük yer almaktadır.)

4. http://lugatim.com (Türk dilinin Osmanlı Türkçesi dönemiyle ilgili sözlük yer almaktadir.)

Çeşitli internet sitelerindeki sözlüklerin yanında yine internet tabanlı uygulamalara dayanan sözlükler de vardır. Bunlar, android veya ios temelli uygulamalar biçimindedir. Bunlarla ilgili de şu sözlükleri örnek vermek mümkündür:

1. http://www.tamga.org/2016/12/android-tabanl-gokturkce-turkce-sozluk.html

2. https://play.google.com/store/apps/details?id=com.mobilsozluk

3. https://play.google.com/store/apps/details?id=com.kubbealti.lugatim 


\section{Sonuç}

İçinde yaşadığımız çağda teknoloji daha da büyük bir hızla gelişmektedir. Buna bağlı olarak özellikle internet tabanlı eğitim-öğretim ve öğrenme faaliyetleri de gittikçe yaygınlaşmaktadır. Bu sebeple, herhangi bir bilgiye ulaşmanın artık en kolay yollarından biri olan internet kaynaklarının güvenilir olanlarının tanıtılması daha büyük bir önem taşımaktadır. $\mathrm{Bu}$ açıdan Türkçenin önde gelen konularından olan yazım, noktalama ve sözlük konusundaki güvenilir kaynakların tanıtımı ve bunlardan yararlanma yolları bu çalışmada örnekleriyle gösterilmiştir. Günümüzde internet kullanımının büyük oranda telefonlar üzerinden gerçekleștirildiği göz önünde bulundurulduğunda her an kişinin yanında olan telefonlarıyla güvenilir kaynaklar üzerinden ihtiyaç duyulan bilgilere ulaşması çağımızın bir gerçeğidir. Dolayısıyla bu eylemin Türkçe yazım, noktalama ve sözlük kullanımı alanlarına da yönlendirilmesi Türkçe açısından gereklidir. Bu çalışmayla da ilgili alanındaki öğretmenlerin, öğretmen adaylarının ve öğrencilerin çağımızın gerektirdiği internet kaynaklarına ulaşmasını kolaylaştırma ve hızlandırma konusunda katkıda bulunmaya çalışılmıștır.

\section{Kaynakça}

Harun, H. M. (2002). Integrating e-learning into the workplace, The Internet and Higher Education, 4/3, 301-310.

Kurbaoğlu, S. (2002). Www bilgi kaynaklarının değerlendirilmesi. Hacettepe Üniversitesi Edebiyat Fakültesi Dergisi, 19/1, 11-25.

Polat, C. (2017). Elektronik kaynak yönetimi. H. Odabaş ve M. A. Akkaya (Ed.), Bilişim Teknolojilerinin Bilgi Merkezlerine ve Hizmetlerine Etkileri (s. 227-252) içinde. İstanbul: Hiperlink.

TÜİK, Hanehalkı bilişim teknolojileri (BT) kullanım araştırması, 2021. Erişim adresi: https://data.tuik.gov.tr/Bulten/Index?p=Survey-on-Information-andCommunication-Technology-(ICT)-Usage-in-Households-and-by-Individuals-2021$\underline{37437}$

TDK. Güncel Türkçe sözlük. Erişim adresi: https://sozluk.gov.tr TDK. Yazım kılavuzu. Erişim adresi: https://www.tdk.gov.tr/tdk/kurumsal/yazim-kilavuzu/ We Are Social \& Hootsuite. Digital 2021. Erişim adresi: https://wearesocial.com/blog/2021/07/digital-2021-i-dati-di-luglio/ 
AN EVALUATION ON THE “STORIES IN THE I. Vol. OF MEVLANA'S MESNEVI"

Osman TÜRK 


\title{
AN EVALUATION ON THE “STORIES IN THE I. Vol. OF MEVLANA'S MESNEVI”
}

\section{Osman TÜRK ${ }^{1}$}

\begin{abstract}
:
Mevlânâ was born on September 30,1207, in the city of Balkh, one of the old Turkish cultural centers, today within the borders of Afghanistan. His real name is Muhammed Celâleddin. His grandfather, Hüseyin Hatibî, was one of the great scholars of his time. His father, Bahâeddin Veled, was known as "Sultânü'l Ulemâ" (Sultân of Scholars). Sultânü'l Ulemâ, an honest person who did not hesitate to speak to anyone, would say everything he knew right in his lessons and sermons without knowing any boundaries. Language is the symbol of being human. Language, which is the necessity of being human, the development of thought and emotion, indispensable of respect and love, is a legacy that nations inherited from the past to the present and the future. It is a known fact that individuals speaking the same language have the same background, culture and values, that is, a common destiny. Our expressions clearly carry the values, norms and social control elements, beliefs and traditions of our nation and play an important role in transferring the above-listed ones to future generations with the help of the language they are a part of. Mevlana has a very important place in the history of Turkish literature. In our study, there will be a language study on volume I based on the book "All Stories in Mesnevi" prepared by Mehmet Zeren. Based on the auxiliary verbs in the stories in the book, the idioms in the sentence will be determined. The idioms determined in the work, the number of lines and the number of pages will be determined. How often the author has used idiomatic word groups and will evaluate the meaning he adds to the sentence.
\end{abstract}

Key words: Mevlana, Mesnevi, İdiom, Language Study.

http://dx.doi.org/10.47832/Lan.con3-2

${ }^{1}$ Harran University, Türkiye, osmanturkgau@ gmail.com, https://orcid.org/0000-0002-9379-6225 


\section{MEVLANA'NIN “MESNEVI’SININ I. CILDINDE GEÇEN HIKÂYELER” ÜZERINE BIR DEĞERLENDIRME}

\section{Öz:}

Mevlânâ, 30 Eylül 1207 tarihinde eski Türk kültür merkezlerinden bugün Afganistan sınırları içinde bulunan Belh şehrinde dünyaya geldi. Asıl adı Muhammed Celâleddin'dir. Büyükbabası Hüseyin Hatibî, yaşadığı dönemin büyük bilginlerindendi. Babası Bahâeddin Veled ise "Sultânü'l Ulemâ" (Âlimler Sultânı) diye anılırdı. Sultânü'l Ulemâ, sözünü kimseden sakınmayan dürüst bir insan, okuttuğu derslerinde ve vaazlarında doğru bildiği her şeyi hiçbir sınır tanımaksızın söylerdi. Dil insan olmanın simgesidir. İnsan olabilmenin gereği, düşünce ve duygunun gelişmişliği, saygı ve sevginin vazgeçilmezliği olan dil, milletlerin geçmişten günümüze ve geleceğe devraldıkları bir mirastır. Aynı dili konuşan bireylerin aynı geçmiş, kültür ve değerlere yani ortak bir kadere sahip oldukları bilinen bir gerçektir. Deyimlerimiz ulusumuzun değer, norm ve sosyal kontrol unsurlarını, inançlarını, geleneklerini belirgin bir biçimde bünyesinde taşımakta ve parçası olduğu dil yardımıyla da yukarıda sıralananları gelecek kuşaklara aktarmada önemli bir rol üstlenmektedir. Türk edebiyat tarihinde Mevlana çok önemli bir yere sahiptir. Çalışmamızda Mehmet Zeren'in hazırladığı “Mesnevi'de Geçen Bütün Hikâyeler” kitabı esas alınarak I. cildin üzerinde bir dil çalışması olacaktır. Kitapta geçen hikâyelerde yer alan yardımcı fiillerden yola çıkarak, cümlede geçen deyimlerin tespiti olacaktır. Eserde belirlenen deyimler, satır sayısı ve sayfa sayısı belirlenecektir. Yazar hangi sıklıkla deyim özelliği taşıyan kelime gruplarına başvurmuş ve cümleye kattı̆̆ı anlam üzerinde değerlendirmede bulunacaktır. Anahtar Kelimeler: Mevlana, Mesnevi, Deyim, Dil Çalışması.

\section{Giriş}

Asıl adı Muhammed olan Celalettin, 30 Eylül 1207'de Horasan'ın Belh'te dünya gelmiştir. Sonraki dönemlerde Celalettin Rumi adıyla anıldı. Arapça bir kelime olan Mevlana, efendimiz anlamı taşımaktadır. Babası bilginler sultanı Bahaeddin Veled, annesi ise Harezmşahlardan Mümine hatundur. Sultan Veled'in Belh'ten ayrılmasının asıl sebeplerinden bazıları ise o dönemde baskıcı bir yapı ve dinsel anlamda zor şartlar altında yaşamasıdır. Dinini icra edenlerin çeşitli cezalara maruz kaldığı bilinmektedir. Sultan Veled'in bu şartlar altında kalması haliyle zorlaşıyordu (Gölpınarlı, 1999). Dönemin önemli alim ve sofilerindendir. Rumi lakabı ise Mevlana'nın önceki dönemlerde Rum diyarı ile anılan Anadolu'ya yerleşmiş, hayatın büyük kısmını da Konya'da idame etmiştir (Batur, 2012). İlk tasavvuf eğitimini Sultan'ül-Ulema diye anılan babası Veled'den almıştır. Daha sonra eğitimi babasının halifelerinden Seyid Burhaneddin Mutakkık-ı Tirmizi'nin yanında tamamladı. Eğitimini tamamladıktan sonra Horasan'a geri döndü. Bugünkü sınırlara baktığımızda Türkmenistan'daki Merv, İran'da Nişabur ve Afganistan'daki Herat ve Belh şehirlerinin bulunduğu Horasan bölgesinin Anadolu'ya bağlanan güçlü izleri vardır. Bu izler Horasan'dan Anadolu'ya ve oradan da dünyaya açllma ve tanınmaya vesile olmuştur. Burada vuslat ve muhabbet kavramlarını temsil etmiştir (Karaismailoğlu, 2015). 13. yüzyılda Afganistan ve Özbekistan Türklerin hâkimiyetine girmiş; Gaznelilerin ve Selçukluların idaresinde bulunan önemli ilim merkezlerinden biri haline getirilmiştir. Mevlana'nın babası Sultan Bahaeddin ve Talebesi Tirmizi 13. Asırda Anadolu'ya gelir. Kendileriyle beraber bir çok alim, şair Anadolu'ya getirirler. Ahmet B. Kani, Sultan İzzeddin Keykavus'a Kelile ve Dimme şiirini çevirerek ona yazar (Köseoğlu, 2012).

\section{Mesnevi}


Mevlana'nın ve dünya edebiyatının en önemli eserinde başında mesnevisi gelir. Diğer eserleri de kıymete haizdir. Eserlerinde kullandığı dil Farsçadır. Yazarın eserlerini anlamak için ciddi bir kültür birikimi gerekiyordu. Fakat eserlerinde işlediği konular hem halkın ilgisini çekmiş hem de ders nitelikte öyküler kaleme almıştır. Genel hatlarıyla ele aldığı konuların başında ilahi aşk ve değişmeceli aşk olmak üzere her alanda ilgi uyandıracak hikâyeler eserinde işlemiştir.

Sayılı eserlerinde içerisinde yer alan mesnevi, birçok dile de çevrilmiştir. Anlatacağı konuları gerek dini kitaplardan gerekse de ayet ve hadisleri ile hikâyeleri bir araya getirerek anlatmaya çalışmıştır. Mevlana ile Feridüddin Atar arasında bir görüşme olduğunu ve Attar'ın Esrarnamesinden etkilenmiş olduğu ve hikâyelerini kullanılmış olduğu ifade eder (Nasr, 1992). 0 dönem itibarıyla bakıldığında eserlerde genellikle hikâye ve fabl örneklerine başvurulduğu görülmüştür. Diğer bir taraftan batıda gelişme alanları göstermeye başlayan öykü, masal, fabl ve ahlak değerleri üzerinde doğu dünyasından aktarılması söylenebilir (Bulaç, 1994). Moğol hâkimiyeti ve egemenliği nedeniyle görüşlerini doğrudan anlatmak sakıncalı olduğu için, aktarma araçları olarak hikâye türünde anlatmayı tercih etmiştir. Mesnevi'nin ilk cildi 1258'de tamamlandığı ifade edilmektedir. Mevlana'nın mihenk taşı olan eserinin ilk 18 beytini kendi yazmış, diğer kısımlarını Mevlana söylemiş, Çelebi Hüsameddin kaleme almıştır. Mesnevi'ye birçok şerhler yapılmış ve bunların içerisinde Abdülbaki Gölpınarlı ve Tariru'l-Mevlevi'nin mesnevisi şerhleri arasında anılabilir.

Dilimizin en zengin yönlerinden biri de deyimlerdir. Büyük çoğunluğu kendi anlamının, yani gerçek anlamının dışında başka anlamlarda kullanan söz gruplarıdır. Deyimler de atasözleri gibi kalıplaşmış sözlerdir. Deyimlerde de sözcüklerin yerleri değiştirilemez; sözcüklerin yerine, eş anlamlı da olsa, başka sözcükler konulamaz. Türkçenin, sosyal hayatın getirdiği yeni kavram, nesne ve durumları anlatmak için söz türetme yollarından biri de deyimselleştirmedir (Sinan, 2008). Deyimler bir kavramı, durumu daha çarpıcı belirtmek, somutlandırmak amacıyla bulunmuş özel bir anlatım kalıbıdır; genel kural niteliğinde bir söz değildir. Toplumun genelini ilgilendiren bir ders, yargı içermez. Deyimler kullandığı duruma, olaya, kişiye özgüdür (Demir, 2006; Türk, 2016). Deyimler; kalıplaşmış, kökleşmiş sözlerdir ve yer değiştirilemez. "Aklı başına gelmek" deyimi "Başı aklına gelmek" şeklinde söylemeyiz. Deyimlerin en önemli grubu, kavramları mecaz yoluyla, anlatım güzelliği içinde veren kalıplaşmış sözcük grubu biçiminde olanlardır (Kurt-Kemal, 1998; Türk, 2016). Sözlük anlamıyla anlatıma akıcılık, çekicilik katan, çoğunun gerçek anlamından ayrı bir anlamı bulunan, genellikle de birden çok sözcüklü dil öğesi, kalıplaşmış sözcük topluluğudur ve bir kavramı kendine özgü bir kalıp içinde, çekici ve hoş bir anlatımla dile getirir (Püsküllü, 2004). Çekici bir anlatım şekli taşıyan ve çoğunun gerçek anlamından ayrı bir anlamı bulunan kalıplaşmış sözcük topluluklarıdır (Aksoy, 1968). Ebüzziya Tevfik'in deyimle ilgili ilk bilgilere dayalı olarak düşüncelerini adlandırmak yerinde olur: Bir duyguyu, düşünceyi, durumu anlatan, bir hüküm ifade etmeyen, çoğu mecazlı olan kalıplaşmış sözlerdir (Duymaz, 2005).

\section{Mesnevinin I. Cildinde Geçen Hikâyeler}

Aşkın Gücü: aşık ol- 17/3: Sevmek, tutulmak., çare bulama- 17/7: Çözüm yolu sağlamak, sorunu çözmek, zorluğu atlatmak, çaresizliği yenmek., dua et-17/9: Allah'a yalvarıp yakarmak., beklemeye başla- 17/16: 1 . Herhangi bir şeyi kısa veya uzun bir süre ertelemek. 2. Telefonla yapılan iletişim sırasında karşı tarafı geçici bir süre bekletmek., harap et- 17/24: Harap duruma getirmek., devam et- 17/24, 19/30: 1.Başlanmış bir iş sürmek. 2. Sürekli, düzenli gitmek. 3. Sürdürmek., kontrol ed- 18/22: Gözden geçirmek, denetlemek. nabzını tut- 18/25,: 1. Nabzını 
saymak için bileğini tutmak. 2. Düşüncesini, niyetini, eğilimini anlamaya çalışmak. yanıp tutuş19/13: 1. Elde etmek için güçlü bir istek duymak, elde edemediği için de büyük üzüntü içinde olmak. 2. Kuvvetli bir aşkla sevmek., sorup öğren- 19/16: Araștırmak, sorup öğrenmek., tembih et- 19/21: Bir şeyin belli biçimde ve yolla yapılmasını istemek, söylemek, uyarmak, yola koyul20/ 3: Gidilecek yere doğru yola çıkıp ilerlemek, yola düzülmek. teslim et- 20/7: 1. Kendinden üstün bir güç karşısında yenilgiyi kabul etmek, mücadeleden vazgeçmek. 2. Kendini teslim etmek, birtakım ellere bırakmak. eser kalma- 20/16: Hiçbir belirti, iz olmamak.

Bakkal ve Papağanın Hikayesi: şaka(lar) yap- 21/4: Şaka niteliğinde bir söz söylemek ya da bir davranışta bulunmak, içeriye dal- 21/9: 1. Kapalı bir yere hızlıca girmek. 2. Bir yere izinsiz girmek., birbirlerine kat- 21/11: 1. Aralarını açmak, aralarını bozmak, olay çıkarmak.2. Karıştırmak., başına vur- 21/13: 1. İçki, gaz, sıcak vb. nedenlerle baş ağrısı yapmak. 2. İstekli olduğu bir konuda, sabrı kalmadığını ve artık duramayacak noktaya geldiğini anlatmak için söylenir. Dayanamaz olmak. 3. Ne yapacağını bilemez hâle gelmek dili tutul- 21/12: Korku, şaşkınlık gibi bir sebepten dolayı söz söyleyemez duruma gelmek, pişman oldu 21/15, saçını sakalı(başını) yol- 21/16: 1. Birini çok fazla dövüp hırpalamak. 2. Çok üzülmek, üzüntüsünden dövünmek., kara kara düşün- 21/21: Çok üzüntülü olmak, düşünceye dalmak., başına vur- 21/3: 1. İçki, gaz, sıcak vb. nedenlerle baş ağrısı yapmak. 2. İstekli olduğu bir konuda, sabrı kalmadığını ve artık duramayacak noktaya geldiğini anlatmak için söylenir. Dayanamaz olmak. 3. Ne yapacağını bilemez hâle gelmek, sebep ol- 22/4: Bir şeyin gerçekleşmesine neden olmak, yol açmak.

Şaşının İnadı: ayak diret- 23/4: Bir şeyde ısrar etmek, karşı koymak, kendi kararından vazgeçmemek, inat etmek, gözden kaybol- 23/12: Ortadan çekilmek, görünmez olmak.

Vezirin Hilesi: başa çık- 23/9: 1. Gücünün üstünlüğünü kanıtlamak, bir şeye gücü yetmek. 2. Şımarmak., yoldan çıkar- 24/13: 1. Bir taşıt bir sebeple yolundan ayrılmak, gitmez olmak. 2. Kötü yola sapmak, doğru yoldan ayrılmak, azgınlığa düşmek. 3. (İş) Düzensiz bir biçimde gitmek., gönülden bağlan- 25/12: İçten, samimi olarak sevgi ve saygı duymak., güven duy- 25/12: Bir kimseye, bir şeye güven beslemek, inanmak, itimat etmek., şüphe et- 25/13: Kuşkulanmak., ifade et- 25/17: Anlatmak., açlık çek- 25/22: Yoksulluk içinde bulunmak., yalnızlı̆̆a çekil- 25/27: Duygularını kimseye açmamak, çevresindeki kişilerle ilişkisini kesmek, yalnızlığa gömülmek., deli divane ol- 25/28: Bir şeyi, bir kimseyi aşırı derecede sevmek, ona tutkun olmak, aşırı derecede ilgi göstermek., mahşer yerine dön- 26/14: Çok kalabalıklaşmak., devam et- 26/18: : 1.Başlanmış bir iş sürmek. 2. Sürekli, düzenli gitmek. 3. Sürdürmek., ortaya çık- 26/18: 1. (Bir durum) Belli olmak, meydana çıkmak. 2. (Bir kimse) Kendini göstermek, görünmek., teselli ol26/18: Avunmak., ortaya çlk- 26/20, 22: 1. (Bir durum) Belli olmak, meydana çlkmak. 2. (Bir kimse) Kendini göstermek, görünmek. toz duman ol- 26/24: 1. Ortalığı altüst etmek, karışıklığa yol açmak, gürültü patırtı çıkarmak. 2. Çok fazla toz kaldırarak koşmak veya kaçmak., birbirine gir- 26/26: 1. Aralarında çıkan anlaşmazlık kavgaya dönüşmek, çarpışmak, saldırmak. 2. Bir kaza sonucu araçların birbirine çarpması. 3. İplik vb. dolaşmak, çözülmeyecek duruma gelmek. 4. Karışmak., muradına er- 26/28: Dileği gerçekleşmek, çok istediği şeye kavuşmak.

Ateşe Atılan Çocuk: ateşe at- 27/4, 6, 15: Birini çok tehlikeli bir işe bile bile sokmak. secde et(mez)- 27/7: 1. Alnı, eli, ayakları, dizleri, ayak parmaklarını yere getirmek. 2. Saygı göstermek., secde et- 27/8, 10: Alnı, eli, ayakları, dizleri, ayak parmaklarını yere getirmek. 2. Saygı göstermek. mahcup ol- 27/17: Utanmak.

Farenin Hilesi: fark edeme- 27/4: 1. Anlamak, sezmek. 2. Bir şey, eskisinden farklı duruma gelmek, değişmek, başkalaşmak. 3. Ayırt etmek. 4. Görmek, seçmek., uçup git- 27/5: Kaybolmak, yok olmak. 
Leyla'nın Cevabı: deli divane ol- 28/1, 5, 9: Bir şeyi, bir kimseyi aşırı derecede sevmek, ona tutkun olmak, aşırı derecede ilgi göstermek. merak et- 28/2: 1. Kaygılanmak. 2. Öğrenmek, anlamak isteği taşımak., dağlara çöllere düş- 28/6: Sıkıntı, üzüntü sebebiyle insanlardan kaçıp ıssız yerlerde yaşar olmak., cevap ver- 28/10: 1. Yanıtlamak, cevaplamak. 2. İhtiyacı karşıllamak, yetmek, yeterli olmak. 3. Olumlu sonuç vermek, yaramak. 4. Söz veya davranışla karşıllk vermek, karşı koymak.

Resullah'a Dil Uzatan Kişi: alay et- 28/1, 29/3: Bir kimsenin, bir şeyin, bir durumun, gülünç, kusurlu, eksik vb. yönlerini küçümseyerek eğlence konusu yapmak, dalga geçmek (alay geçmek)., ağzını eğ- 28/2, 2, 3: Yalvarmak, hiç de lâyık olmayan birine yüz suyu dökmek. pişman ol- 28/4: Yaptığı bir işin yanlış olduğunu ya da uygunsuz sonuç verdiğini, söylediği bir sözün yerinde olmadığını anlayarak üzülmek.

Hz. Hud'un Mucizesi: içinde ol- 29/4: Bir yerin merkezinde yaşamak veya orada doğmuş bulunmak.

Şeyban-ı Rai'nin Hikayesi: zarar vereme- 29/4: 1. Kötülük etmek. 2. Birinin parasal kayba uğramasina sebep olmak.

Aslan ile Tavşan: bir araya gel- 29/2: Belirli bir zamanda ve yerde toplanmak, buluşmak., teklif et- 30/1: Önermek, öne sürmek., emin ol- 30/5: İnanmak, güvenmek., razı ol- 30/5, 9: Uygun bulmak, beğenmek, benimsemek, istemek, kabul etmek., devam ed- 30/7, kura çek30/10: İki veya daha fazla aday arasında bir sıralama, bir ayırma yapılacağı zaman her birinde bir tek ad yazılı kâğıtları bir araya getirip karıştırdıktan sonra birini çekerek veya özel bir bilgisayar yazılımıyla adları belirlemek., isabet et- 30/10: 1. Nişan alınan yere değmek, rastlamak. 2. Çıkmak. 3. Yerinde iş görmüş olmak., teslim ol- 30/11: 1. Kendinden üstün bir güç karşısında yenilgiyi kabul etmek, mücadeleden vazgeçmek. 2. Kendini teslim etmek, birtakım ellere bırakmak., rahat et- 30/11: Sıkıntısız durumda olmak, ferahlanmak, dinlenmek., perişan et- 30/19: 1. Dağıtmak, düzenini bozmak. 2. Acınacak hâle getirmek., merak et- 30/21, 25: 1. Kaygılanmak. 2. Öğrenmek, anlamak isteği taşımak., arz et- 31/6: 1. Göstermek. 2. Sunmak. 3. Saygı ile bildirmek, bilgisine sunmak., razı et- 31/11: Kabul ettirmek., söze başla- 31/13: Konuşmaya başlamak, bir konuya girmek., yola çık- 31/14: 1. Bir yere gitmek üzere bulunduğu yerden ayrılmak. 2. Herhangi bir şeyi esas almak, oradan başlamak. 3. Bir vasitaya binmek üzere yol üstünde durmak., aklı başında git-31/25: 1. Çok korkudan veya çok sevinçten ne yapacağını şaşırmak. 2. Kafası çok yorulmuş olduğundan iyi düşünememek., ayaklarım tutmaz ol- 32/5: Yürüyemeyecek duruma gelmek.

Azrail'in Tuhafına Giden Şey: tir tir titre- 32/2: 1. Çok üşümek. 2. Çok korkmak., soluk soluğa cevap ver- 33/1: Zor nefes alarak; heyecan, telâş, yorgunluk veya bitkinlikle; koşmaktan güçlükle, sık sık soluyarak., hışımlı bak- 33/2, 33/21 korku düş- 33/3: Endişelenmek, korkmak., adelet kapınıza sığın- 33/4: Birinden anlayış, hoşgörü, yakınlık beklemek., korkudan kurtul- 33/11, Ummadığı bir durumda kalmak, şaşkınlık içine düşmek.

Hüdhüd ile Karga: sayıp dök- 34/2: Ne var ne yok hepsini söylemek, arka arkaya sıralamak., yüzünü kara et-35/17: Yaptığı bir iş ya da davranışla birini utandırmak, mahcup duruma düşürmek. mahkum olmaz- 35/19: 1. Yargılanıp ceza almak, hüküm giymek. 2. Kötü bir duruma düșmek. 3. Mecbur olmak.

Papağanın Hikayesi: mahkum ol- 36/1: 1. Yargılanıp ceza almak, hüküm giymek. 2. Kötü bir duruma düşmek. 3. Mecbur olmak, yola koyul- 36/19: Gidilecek yere doğru yola çıkıp ilerlemek, yola düzülmek., nefesi kesil- 37/5: 1. Güç soluk alacak duruma gelmek veya soluğu büsbütün durmak. 2.Etkilenmek, hayran olmak., sebep ol- 37/7: Bir şeyin gerçekleşmesine neden olmak, yol açmak., ısrar et- 37/21: 1. Bir konuda, bir düşüncede sürekli direnmek, ayak 
diremek. 2. Çok istemek., hareketsiz kal- 37/25: 1) yapılması düşünülmüş olduğu hâlde yapılmamak; 2) kararı bağlandığı hâlde uygulanmamak., 38/2, pişman ol- 37/27: yaptı̆̆ı bir işin yanlış olduğunu ya da uygunsuz sonuç verdiğini, söylediği bir sözün yerinde olmadığını anlayarak üzülmek., aklı başından git- 38/3: 1. Çok korkudan veya çok sevinçten ne yapacağını şaşırmak2. Kafası çok yorulmuş olduğundan iyi düşünememek., ağlayıp sızlamaya baş- 38/3: 1. sızısı olmak, kendisinde bir sızı ortaya çıkmak. 2.sızlanmak, yakınmak, şaşıp kal- 38/11: Çok şaşırmak, büyük bir şaşkınlığa düşmek.

Çalgıcının Hikayesi: ekmeğe muhtaç ol- 39/4: İhtiyaç duyduğu bir şeyi başkasından sağlamak zorunda bırakmak, baştan başa dolaş- 40/12: Tamamıyla, hepsi, bütünüyle. Bir uçtan öteki uca, başından sonuna değin, pişman ol- 40/21: Yaptığı bir işin yanlış olduğunu ya da uygunsuz sonuç verdiğini, söylediği bir sözün yerinde olmadığını anlayarak üzülmek.

Hz. Salih'in Devesi: helak ol- 42/19: 1. Yok olmak, ölmek. 2. Yorulmak, bitkin duruma gelmek.

Bedevi'nin Armağanı: haddi hesabı yok- 43/3: Sayılamayacak kadar çok, sınırsız, ölçüsüz., şikayete baş- 43/5: 1. Sızlanmak, yakınmak. 2. Bir görevlinin yaptığı yanlış bir işi ya da davranışı daha üst makamlara bildirmek., diller dök- 43/6: Bir kimseye bir şeyi yaptırmak ya da ona yaranmak amacıyla onun hoşlanacağı şeyler söylemek., nasihatler et-43/6: Bir kimseye yapması veya yapmaması gereken şeyler için yol göstermek, öğüt vermek, öğütte bulunmak., gözyaşı dök44/2: Ağlamak., fırsatını yakala- 44/5, eli boş var- 44/11: 1. Hediyesiz gelmek. 2. Umulan şeyi getirmeden gelmek., yollara düşmek 44/19: Bir zorunluluk sebebiyle yola çıkmak, yolculuğa başlamak., mahcup ol- 45/3: Utanmak., hayretler içinde kal- 45/4: Şaşakalmak, şaşırmak.

Bir Kazvinlinin Hikayesi: rivayet et- 45/1: Bir olay, bir haber vb. anlatılmak., işe koyul45/13: Bir işi yapmaya başlamak, işi yapmayı sürdürmek., feryat ed- 45/15: 1. Yüksek sesle haykırmak. 2. Büyük bir yokluk, zarar ve sıkıntı içinde bulunmak., canım burnuma gel- 46/6: Bir şey yaparken çok eziyet ve zorluk çekmek, bunalmak.

Ava giden Aslan Kurt ve Tilkinin Hikayesi (Aslan Payı): ağrına gid- 47/5: Bir söz, bir davranış bir kimsenin onuruna dokunmak, o kimseye ağır gelmek.

Sevgilinin Cevabı: kapısına gel-, git- 49/13, 49/1: Birisinden yardım istemek.

Hz. Yusuf a Uygun Hediye:, eli boş gid- 50/6: 1. Hediyesiz gelmek. 2. Umulan şeyi getirmeden gelmek., karar ver- 50/15: Bir sorunu karara bağlamak, kararlaştırmak.

Sağırın Hasta Ziyareti: hal hatır bil- 51/1: Bir kimseye "Nasılsınız? Ne durumdasınız?" biçiminde nezaket sorusu sormak., haber ver- 51/3: 1. Bildirmek, haber ulaştırmak. 2. Bir durumun, bir olayın belirtisi olmak., cevap ver-51/10, 12: 1. Yanıtlamak, cevaplamak. 2. İhtiyacı karşılamak, yetmek, yeterli olmak. 3. Olumlu sonuç vermek, yaramak. 4. Söz veya davranışla karşılık vermek, karşı koymak., canı çok sıkıl- 52/9: 1. Yapılacak bir işi olmadığından huzursuz olmak. 2. Bir olay nedeniyle keyifsiz olmak, üzülmek. 3. Öfkelenmek., devam et- 52/18: 1. Başlanmış bir iş sürmek. 2. Sürekli, düzenli gitmek. 3. Sürdürmek., halini hatırını sor- 53/2Bir kimseye "Nasılsınız? Ne durumdasınız?" biçiminde nezaket sorusu sormak.

Arada Perde Kalkınca: kulağına git- 53/7: Duymak., üstün ol- 53/14: 1. Benzerlerinden daha yüksek düzeyde olmak. 2. Bir kimseden veya bir şeyden daha yüksek, daha değerli olmak., karar ver- 53/14: Bir sorunu karara bağlamak, kararlaştırma, haber ver- 54/14: 1. Bildirmek, haber ulaştırmak. 2. Bir durumun, bir olayın belirtisi olmak., taktir ed- 54/17: 1. Beğenmek. 2. Önemini, gerekliliğini, değerini anlamak. 3. Değer biçmek, değerlendirmek., mümkün ol- 54/26: İmkân bulunmak.

Lokman ve Köleler: ortaya çık- 55/11: 1. (Bir durum) Belli olmak, meydana çıkmak. 2. (Bir kimse) Kendini göstermek, görünmek. 
Hz. Ömer'in Yangını söndürmesi: çare bulama- 56/2: Çözüm yolu sağlamamak, sorunu çözememek, zorluğu atlatmamak, çaresizliği yenememek., yardım et- 56/3, 8, 14: İmkânlarını ve gücünü başka kişilerin iyiliği için kullanmak., itiraza başla- 56/10: Bir düşünce veya kararı benimsemeyerek karşı çıkmak. merhamet et- 56/18: Acımak, hâline üzülmek.

Hz. Ali'nin Düşmanını Öldürmesi: serbest bırak- 57/12: 1. Tutuklu veya gözaltında bulunan birini serbest, özgür duruma getirmek, tahliye etmek. 2. Kendi düşüncesi ve iradesine göre davranmasına izin vermek.

\section{Sonuç}

Çalışma sonucunda Mesnevi'nin I. cildinde geçen bütün hikâyeler isimli eser incelenmiştir. Deyimler hikâyelere canlılık ve zenginlik katmıştır. Konunun genişlenmesinde ve zenginleşmesinde deyimlerin katkıları olmuştur. Eserde yer alan deyimler, o dönemde cereyan eden olayları daha güzel ve sağlıklı anlatmasına yardımcı olmuştur. Çünkü vurgulanmak istenen olaylar için deyimlere yer vermiştir. Bu anlamda bakıldığında cümleye anlatım yönünde derinlik katmıştır. Hikâyeler ise son derece güzel bir yalınlık içindedir. Hikâyedeki olaylar anlatırken gerçekçi bir tarz ve doğalcılık akımı göze çarpmaktadır. Hikâyede sürükleyici bir akış vardır, yani konunun gelişimini yalnızca olayların akıșına bırakılmıștır. Mesnevi'de Geçen Bütün Hikâyeler isimli eserini dil ve anlatım özelliği bakımından değerlendirdiğimizde yazar, zaman kiplerini kullanmış ve genellikle üçüncü tekil şahıs eki bakımından cümleleri kurduğu görülmektedir. Hikâyede kullanılan dil; sade, açık ve yalındır.

\section{Öneriler}

Mehmet Zeren'in "Mesnevi'de Geçen Bütün Hikâyeler" ele alınan bu eser için daha detaylı çalışma yapmak isteyenlere bir ön malzeme olarak önerilmektedir. Elde edilen sonuçların deyimler konusunda çalışma yapmak isteyen araştırmacıların veri kaynağı olacağını düşünülmektedir. $\mathrm{Bu}$ araştırmada romanda tespit edilen deyimler vasıtasıyla ortaöğretim öğrencilerine Mehmet Zeren'in “Mesnevi'de Geçen Bütün Hikâyeler eserinde kullanmış olduğu dil ve üslubu hakkında bilgi verme yönünden yardımcı kaynak niteliği taşıyabilir. Eser öğrencilere okuma alışkanlığını kazandırma, anadilin sağlıklı bir șekilde kullanabilme, hayata geniş çevrenden bakabilme gibi nitelikler kazanmasını sağlayabilir:

- Öğrencilerin deyimler konusundaki bilgilerini arttırmak için kaynak olarak verilebilir.

- Öğretmen, öğrencilere deyimler hakkında inceleme konusu olarak verilebilir.

- Deyimlerin dil ve anlatımına ne gibi özellik ve zenginlikler kattığı, katabileceği konusunda öğrencilere açıklama yapmada, öğretmenler tarafından bu konuda yardımcı eser olarak kullanılabilir.

- Titizlikle yapılan bu çalışma ileriki zamanlarda buna benzer yapılacak çalışmalara da ön kaynak niteliği taşıyacağı umulmaktadır.

\section{Kaynakça}

Bulaç, Ali. (1994). İslam Dünyasında Din-Felsefe, Vahy-Akıl İlişkisi. İstanbul.

Batur, Suat. (2012). Mevlana. İstanbul: Altın Yayınlar.

Demir, Tufan. (2006). Türkçe Dilbilgisi. Ankara: Kurmay Yayınevi

Duru, Muhittin Celal. (1964). "Mevlana Eserlerinin Orijinal Nüshaları”. Türk Yurdu, c.3.

Gölpınarlı, Abdülbaki. (1959). Mevlana Celaleddin. İstanbul.

Gölpınarlı, Abdülbaki. (1999). Mevlana Celaleddin Rumi. İstanbul: İnkılap Yayınları.

Karaismailoğlu, Adnan. (2012). Mesnevi. Ankara: Akçağ Yayınları. 
Köseoğlu, Nevzat. (2012). Türk Dünyası tarihi ve Medeniyeti Üzerine Düşünceler. İstanbul: ÖtükenYayınları.

Nasr, Seyyid Hüseyin. (1992). İslam Sanatı ve Maneviyatı, Çev. Ahmet Demirhan. İstanbul.

Sinan, Ahmet Turan. (2008). Deyim Kavramı Üzerine Notlar - 1. Fırat Üniversitesi Sosyal Bilimler Dergisi 18(2), 91-98

Türk, Osman. (2016). Hamza-nâme adlı eserin 72. Cildinin Atasöz, Deyim, İkileme ve Beyitlerin anlam ve görev yönünden İncelenmesi. Akademik Sosyal Araştırmalar Dergisi, Yll: 4, Sayı: 24, Mart 2016, s. 325-334.

Türk, Osman. (2016). Şehriyar'ın Türkçe Divanı Olan “Haydar Babaya Selam Şiiri”nin Türkçe Deyimleri Üzerine Bir Değerlendirme. Akademik Sosyal Araştırmalar Dergisi, Yıl: 4, Sayı: 28, Temmuz 2016, s. 464-470 
ONTOLOGICAL THEORY IN LITERATURE

Levent BILGI 


\title{
ONTOLOGICAL THEORY IN LITERATURE
}

\author{
Levent BILGI $^{1}$
}

\begin{abstract}
:
Ontological theory has developed with unnamed ideas since Aristotle. Roman Ingarden talked about the layers of being in his works of art. Ontology has come to the fore especially when analyzing the texts of poetry. Ontological theory works by not paying attention to extra-textual elements in the analysis of a text. It focuses on the text itself. It tries to understand the layers of literary text. Ontological Theory in Turkish Literature came to the forefront with Takyettin Mengüşoğlu and İsmail Tunalı's work called Art Ontology. İsmail Tunalı's work named Art Ontology has been published. After the publication of Art Ontology, it is seen that the publications on ontology have increased. Later, Ontological Theory gradually became one of the criteria for evaluating the work of art in our literature.
\end{abstract}

Key words: Ontology, Theory, Art, Work, Criticism.

http://dx.doi.org/10.47832/Lan.con3-3

${ }^{1}$ Harran University, Türkiye, leventbilgi@gmail.com 


\section{EDEBIYYATA ONTOLOJİK KURAM}

\section{Öz:}

Ontolojik kuram Aristo'dan bu yana ismi koyulmamış düşüncelerle gelişmiştir. Roman Ingarden sanat eserlerinde varlık tabakalarından bahsetmiştir. Ontoloji özellikle şiir metinlerini tahlil ederken ön plana çımıştır. Ontolojik kuram bir metnin çözümlenmesinde metin dışı unsurlara dikkat etmeyerek çalışır. Metnin kendisine odaklanır. Edebi metnin katmanlarını anlamaya çalışır. Türk Edebiyatında Ontolojik Kuram Takıyettin Mengüşoğlu ile ve İsmail Tunalı'nın Sanat Ontolojisi adlı eseri ile ön plana çıkmıştır. İsmail Tunalı'nın Sanat Ontolojisi adlı eseri yayımlanmıştır. Sanat Ontolojisi'nin yayımlanmasından sonra ontolojiyle ilgili yayınların arttığı görülmektedir. Daha sonra yavaş yavaş Ontolojik Kuram edebiyatımızda sanat eserini değerlendirme ölçülerinden biri haline gelmiştir.

Anahtar Kelimeler: Ontoloji, Kuram, Sanat, Eser, Tenkit.

\section{Giriş}

Edebiyatta ontolojik kuram özellikle Nikolai Hartmann ve Roman Ingarden'ın düşüncelerinden faydalanılarak geliştirilmiştir. Sanat eserlerinde varlık tabakalarından söz eden ilk estetik bilimci Roman Ingarden olmuştur. Ingarden'dan önce R.Coclenus (1613) ve Christian Wolff (1754) tarafından "ontoloji" terimi kullanılmışsa da, bu kullanımlarda ontolojiyle sanat eseri arasında herhangi bir bağlantı kurulmamıștır. Ontolojiyi sırf bir felsefî disiplin olarak değerlendiren Christian Wolff'dan sonra 1930 'da R.Ingarden sanat eserlerinde varlık tabakalarından söz ederek hem ontolojiye; hem de estetik bilime yepyeni bir bakış açısı kazandırmıştır. Aristo'nun da varlık aramaları, sorgulamaları ile ontolojiye düşünceleriyle katkıda bulunduğunu söylemek mümkündür.

Ontoloji özellikle şiir metinlerini tahlil ederken ön plana çıkmıştır. Ontolojik kuram bir metnin çözümlenmesinde metin dışı unsurları bir kenara bırakarak, metnin kendisine odaklanılması disiplini tarzında çalışır. Edebî metnin katmanlarının anlaşılmasında ontolojik kuramın önemli bir payı vardır.

Edebiyatta Ontolojik Kuram

Türk Edebiyatında ontolojik kuram Hartmann'ın öğrencisi Takıyettin Mengüşoğlu ile ve İsmail Tunalı'nın Sanat Ontolojisi adlı eseri ile ön plana çımıştır. Tunalı, Roman Ingarden ve Nikolai Hartman'ın sanat eserlerinde varlık tabakaları ile ilgili görüşlerini ayrıntılı biçimde ve kendi düşüncelerini de ilave ederek incelemiştir. Daha sonra bu metodu Yahya Kemal'in "Sessiz Gemi” ve Cahit Sıtkı'nın “Gün Eksilmesin Penceremden” başlıklı şiirlerinde uygulamıştır. (Tunalı, 1971:58)

Ontolojiyle ilgili olarak Türkiye'de ilk yayın, 1920'de Dârülfünûn Matbaasında basılmış olan Rıza Tefvik'in Mabade't-tabîa Dersleri, Ontoloji Mebâhisi'dir. Daha sonra 1959'da Hartmann'ın öğrencisi olan Takıyettin Mengüşoğlu'nun bir makalesi ve 1965'te İsmail Tunalı'nın Sanat Ontolojisi adlı eseri yayımlanmıștır. Sanat Ontolojisi'nin yayımlanmasından sonra ontolojiyle ilgili yayınların arttığı görülmektedir.2 (Yavuz, 2008: 3)

\footnotetext{
${ }^{2}$ Ontoloji ile ilgili yayınlar için bakınız: Bayram Yavuz, "Divan Şiiri Metinlerinin Ontolojik Tahlili”, Prof.Dr.Abdülkadir Karahan Anısına Uluslararası Divan Edebiyatı Sempozyumu, 27-28 Mayıs 2008, Beykoz Belediyesi Yay., İstanbul 2008, s.3/4.
} 
İsmail Tunalı'nın geliştirdiği yöntem, birçok araştırmacı tarafından uygulanmıştır. Özellikle Yavuz Bayram'ın "Divan Şiiri Metinlerinin Ontolojik Tahlili Üzerine adlı çalışmasında geliştirdiği tablo, birçok araştırmacı tarafından kullanılmıştır.

Nikolai Hartman, bir sanat eserinin yapısını ilkin ön yapı ve arka yapı şeklinde ikiye ayırır. "Ön yapı, açık olarak bilinen bir tabakadır; bağımsız, ontik bakımdan kendi başına var olan reel tabakadır. Arka yapı ise asıl tinsel içeriktir, objektivation'da asıl söz konusu olan şeydir ama o, bağımsız bir varlık tarzına sahip değildir." Ancak "Bu iki yapı öyle iç içe girmiş, öyle girift olmuştur ki sadece bir tek objeymiş gibi görünür"ler. (Tunall, 1971:61)

Ancak sanat eserinin estetik değerinin anlaşılmasında sanatçı ve okuyucunun ihmal edilmesi ontolojik kuramın bir çıkmazı olarak değerlendirilmiştir.

Sanat eserlerinin kendi içinde bir sistem olduğunu ve bu sistemin dış unsurlardan bağımsız bir şekilde incelenmesi gerektiğini iddia eden yapısalcılık ve biçimcilik gibi yaklaşımlar ontolojik yöntemin ortaya çıkmasını etkilemiştir. Ancak bu iki metodun mekanikliğine karşılık ontolojik kuram daha derinlikli ve içseldir.

Ontoloji için kısaca varlık felsefesi diyebiliriz. Daha kapsamlı bir ifadeyle ise ontoloji, metafiziğin tek tek nesne ve olaylarla değil, genel olarak varlık problemleriyle ilgili olan dalı; varlığı varlık olarak, varlık olma bakımından ele alan bilimdir. (Cevizci, 2013: 1192).

Ontoloji teriminin kökeni, Yunanca varlık anlamındaki ontos ile bilgi anlamındaki logos kelimelerine dayanmaktadır. Osmanlı Türkçesinde varlık bilimi teriminin karşılığı sayılabilecek mebhas-i vücûd, ilmü'l-kevn, felsefe-i u'lâ, ilmü'l-mükevvenât ve mebhas-i ledünniyât gibi terkipler dikkat çekmektedir. Günümüz Türkçesinde ise ontoloji teriminin karşıllğı olarak daha çok varlıkbilim teriminin tercih edildiği görülmektedir. Ontoloji, en basit tanımıyla varlığın bilgisi, özü, anlamı üzerine bilimdir. (Yavuz, 2008:167-182)

"Sanat eserinin varlı̆̆ı, bir şiirin, bir heykelin, bir müzik parçasının varlığı nasıl bir varlıktır. Sanat eserinin varlığı ile öbür varlıklar arasında nasıl bir ilgi ve ayrılık vardır? Sanat eserinin ontik yapısı nedir? Bu yapı ile sanat eserine yüklediğimiz değer arasında nasıl bir ilgi vardır? Soruları da ontoloji için ele alınması ve çözümlenmesi gereken ontolojik sorulardır. Sanat eserinin ontik yapısını araştıran bir ontoloji gereklidir." (Tunalı, 1971:47)

İlk çağlardan beri insanlar varlığın kökenini aramış merak etmişlerdir. Dinler bu soruya cevap vermek için ortaya çıkmış, ancak dinî düşüncelerin aslından uzaklaşıp bozulmasıyla varoluş soruları baskılanmış, yasaklanmıştır. Thales'ten Herakleitos'a, Descartes'e kadar pek çok düşünür varoluş sorunu ile ilgilenmiş, teoriler geliştirmişlerdir.

Yirminci yüzyılın başlarında sosyoloji ve psikolojideki gelişmelere paralel olarak, eseri sosyoloji ve psikoloji çerçevesinde incelemek ön plana çıkmıştır. Ontoloji tabirini ilk kullanan, Alman filozofu Christian Wolff (1679-1754)'dur. Nikolai Hartmann'a göre ise “Bilgi daima aşkındır, onun için önemli olan nesnenin nasıl düşünüldüğü değil, nesnenin nasıl olduğudur; tüm bilgi donanımı da nesnenin kavranması içindir" (Hartmann, 2010:8) Hartmann'ın yeni ontolojisi sanat eserini bir var olan olarak ele almayı hedefler.

Var olan her şey ontolojinin çalışma alanına girer. Sanat eseri, var olan her şeyi varoluşu bakımından inceler. Ontolojik kuramda sanat eseri her şeyden bağımsız olarak varlı̆̆ ve varoluşu merkeze alınarak ele alınır. Eserin kökeni ve kaynağı onu anlamak için önemlidir. Heidegger'e göre sanatçının varoluşu sanat eserinde ortaya çıkar. Sanatçı eserinde kendi varlığının özelliklerini gösterir. Sanat faaliyeti bir süreçtir ve bu sürecin ilk başladığı yer sanatçının kendisidir. Sanatçı eserin ilk sebebidir. Ontolojik kuram sanatçı üzerine yoğunlaşmaz ama eser ele alınırken sanatçı tamamen de ihmal edilmez. 
Roman Ingarden, edebî eserde her şeyin belirlenemeyeceğini, metinde bazı belirsizliklerin başka bir ifadeyle anlam boşluklarının mevcut olduğunu söyler. Okuyucu var olan anlam boşluklarını kendine göre doldurarak metni alımlar. Okuyucu anlam boşluklarını doldururken aynı zamanda edebî eserden alımladığı anlamları başka alanlarla bağdaştırarak yeni anlam tabakaları kurar. Ingarden bu durumu yeniden kurma olarak isimlendirir. Edebiyat yapitlarında, okur ve metin arasında oluşan etkileşim sırasında metnin anlamı oluşur. Anlama sürecini yöneten okuyucunun kültürü, düşünceleri, beklentileridir. Okurun duruşu, edebî metinde olmayan ama okuma sırasında meydana gelen anlamları çözer.

Ingarden, edebî metni ontik bir bütün olarak ele alırken okuyucunun önemine dikkat çeker. Ona göre okur edebî eserdeki varoluşsal ilişkileri kurarak bir yapı oluşturur. Bu yapıyı daha sonra beklentilerine ve ön bilgililerine göre dönüştürür. Edebî metnin anlamı böylece okuyucunun karakterine ve kültürüne göre oluşur. Metnin ontik bütünlügü, okuyucunun anlamlandırması sayesinde meydana gelir. Okuyucunun eğitimi, kültür düzeyi, ideolojik tercihleri, inançları, kişilik yapısı, yaş gibi unsurları onun eser karşısındaki duruşunu, algılama tarzını belirler. Bu gibi değișken faktörlerden dolayı her okuyucunun beklentisi farklıdır. Dolaysıyla her okuyucu metni kendine göre anlamlandırır.

Bütün yukarıdaki yazar ve okuyucu görüşlerine rağmen ontolojik metot bir metin merkezli yöntemdir. Bu kuramda asıl olan sanat eseridir. Mümkün olduğu kadar eser ve sanatın dışına çıkılmadan çözümlemelerde bulunulur. Bu anlamda diğer yöntemlere göre daha objektif olduğu söylenebilir. Anlam katmanları bizzat eserin içinde aranır. Sanatçı ve okuyucu her zaman eser ile beraber değerlendirilir. Birbirinden ayrı düşünülemez.

\section{KAYNAKLAR}

BAYRAM Yavuz, (2008). "Divan Şiiri Metinlerinin Ontolojik Tahlili”, Prof.Dr.Abdülkadir Karahan Anısına Uluslararası Divan Edebiyatı Sempozyumu, 27-28 Mayıs 2008, Beykoz Belediyesi Yay., İstanbul.

CEVIZCİ, Ahmet (2013). Paradigma Felsefe Sözlüğü, Paradigma Yayınları, İstanbul.

HARTMANN, Nicolai (2010). Ontolojinin Ișı̆ı̆ında Bilgi (Çev. Harun Tepe), Türkiye Felsefe Kurumu, Ankara. TUNALI, ismail, (1971) Sanat Ontolojisi, İ.Ü.Edebiyat Fakültesi Yayınları, İstanbul. 
A COMPETITION TO FIND AN EQUAL TO THE TWELVE FOREIGN WORDS ORGANIZED BY THE ŞEHBÂL MAGAZINE (1909-1914)

Mehmet Emin TUĞLUK 


\title{
A COMPETITION TO FIND AN EQUAL TO THE TWELVE FOREIGN WORDS ORGANIZED BY THE ŞEHBÂL MAGAZINE (1909-1914)
}

\author{
Mehmet Emin TUĞLUK ${ }^{1}$
}

\begin{abstract}
:
One of the important magazines of the Second Constitutional period was the magazine Şehbâl, which was published between 14 March 1909 and 14 July 1914. Political events and comments in Şehbâl magazine; culture, literature, music; painting, sculpture, architecture; health,sport; inventions and inventions, discoveries, accounting, humor, fashion, make-up, embroidery, housework; articles on many subjects such as information about new publications and selections from English, French, German and American magazines have been published. Another important feature of Şehbâl magazine is that it organizes competitions on various subjects. One of these competitions organized by the Magazine is The Competition to Find an Equal to The Twelve Foreign Words In this competition, it was requested to find the equivalents of the words bibliographie, boycottage, caprice, caricature, clup, conference, concert, decor, monologue, paradoxe, surprise, taximetre. Various words were suggested to this competition by 517 people. However, none of the suggested words are used in standard Turkey Turkish instead of the desired word. However, this competition is important in terms of showing the influence of foreign languages on Turkish and the awareness and resistance shown against this influence.

Key words: Şehbâl Magazine, Competition, Second Constitutional, Foreign Languages, Turkish Equivalent.
\end{abstract}

http://dx.doi.org/10.47832/Lan.con3-4

${ }^{1}$ Batman University, Türkiye, emintugluk@ gmail.com, https://orcid.org/0000-0003-1866-5580 


\section{ŞEHBÂL DERGIISİ (1909-1914) TARAFINDAN DÜZENLENEN ON İKİ KELİME-İ ECNEBIYYEYE TÜRKÇEDE MUKÂBİL BULMAK MÜSÂBAKASI}

\section{Öz:}

II. Meşrutiyet döneminin önemli dergilerinden biri 14 Mart 1909-14 Temmuz 1914 tarihleri arasında yayımlanan Şehbâl dergisidir. Şehbâl dergisinde siyasi olaylar ve yorumlar; kültür, edebiyat, musiki; resim, heykel, mimari; sağlık, spor; icatlar ve keşifler, muhasebe, mizah, moda, makyaj, dikiş nakış, ev işleri; çıkan yeni yayınlar hakkında bilgiler ile İngiliz, Fransız, Alman ve Amerikan dergilerinden seçmeler gibi pek çok konuda yazılar yayımlanmıştır. Şehbâl dergisinin önemli diğer bir özelliği de çeşitli konularda müsabakalar düzenlemesidir. Derginin düzenlediği bu müsabakalardan biri de On İki Kelime-i Ecnebiyeye Türkçede Mukâbil Bulmak Müsâbakası'dır. Bu müsabakada bibliographie, boycottage, caprice, caricature, clup, conference, concert, decor, monologue, paradoxe, surprise, taximetre kelimelerine karşllı bulunması istenmiştir. Bu müsabakaya 517 kişi tarafından çeşitli kelimeler önerilmiştir. Ancak önerilen kelimelerin hiçbirisi karşılığı bulunması istenen kelime yerine standart Türkiye Türkçesinde kullanılmamaktadır. Bununla birlikte bu müsabaka Türkçe üzerinde ecnebî dillerin tesiri ile bu tesire karşı oluşan bilinç ve gösterilen direnci göstermesi açısından önemlidir.

Anahtar Kelimeler: Şehbâl Dergisi, Müsabaka, II. Meșrutiyet, Ecnebî Diller, Türkçe Karşıllk.

\section{Giriş}

Osmanlı Devleti'nde Tanzimat ile birlikte pek çok alanda zihniyet değişikliği yaşanmıștır. Zihniyet değişikliğinin yaşandığı alanlardan biri de "dil" konusudur. Bu dönemde Şinasi ve Mustafa Reşit Paşa gibi Tanzimat aydınları tarafından gazeteler aracılığıyla savunulan dilde sadeleşme hareketi neredeyse dönemin tüm aydınlarının ortak meselesi olmuştur. Ziya Paşa, Namık Kemal, Münif Paşa, Ahmet Cevdet Paşa, Ali Suavi, Ahmet Vefik Paşa gibi aydınlar konu ile ilgili yazılar kaleme almışlardır. Dilde sadeleşme hareketi II. Meşrutiyet dönemi aydınlarının da gündeminde olmuştur. Gerek Tanzimat gerek Meşrutiyet dönemi aydınları dilde sadeleşme konusunu; dilde yabancı kökenli sözcüklere karşllı bulunması, Arapça ve Farsça kökenli tamlamaların durumu, Türk dili ile ilgili kapsamlı bir sözlük oluşturulması, Türk dili ile ilgili bir cemiyet oluşturulması konuları kapsamında ele almışlardır. II. Meşrutiyet döneminde süreli yayınlar etrafında dönen bu tartışmalara dönemin önde gelen dergilerinden Şehbâl On iki Kelime-i Ecnebiyeye Türkçede Mukâbil Bulmak Müsâbakası düzenleyerek farklı bir boyut kazandırmıştır.

\section{1. Şehbâl Dergisi}

II. Meşrutiyet döneminin önemli dergilerinden biri 1909-1914 yılları arasında beş yıl boyunca ve toplamda 100 sayı olarak yayımlanan Şehbâl dergisidir². Derginin imtiyaz sahibi ve sorumlu müdürü Hüseyin Sadettin (AREL) idare müdürü Jack Sabalyan'dır. Derginin ilk sayısı 1 Mart 1325 (14 Mart 1909) son sayısı ise 1 Temmuz 1330 (14 Temmuz 1914) tarihinde yayımlanmıştır. Dergi Agop Mattesyon (İstanbul) matbaasında basılmıştır. Derginin ilk sayfalarının kapağında "On beş günde bir neşrolunur ve her şeyden bahseder, risâle-i musavvere" ibaresi yer almaktadır. Dergi 8. sayı dışında 20 sayfa olarak basılmıştır. Derginin sayfa ebatları geniş tutulmuş böylece hem sayfa sayısının azaltılması hem de verilmek istenen konuların bir bütün olarak bir arada verilmesi amaçlanmıştır.

\footnotetext{
${ }^{2}$ Şehbâl dergisi hakkında bilgi için bk. Selim Ahmetoğlu, Şehbal Mecmuası (1909-1914) Ittihatçı Aktüaliteden Kitlesel Popülariteye. İstanbul: Libra Kitap, 2010; Selim Ahmetoğlu, From the Unıonist Actualté to the Mass Popularity: Şehbâl (1909-1914). İstanbul: Boğaziçi Üniversitesi, Sanat Tarihi Bölümü, Yüksek Lisans Tezi, 2007.
} 
Döneminin siyasetten uzak kalan dergileri arasında sayılan Şehbâl, genel olarak kültür, sanat, edebiyat3, aile, magazin vb. konulara yer vermiştir. "Şehbâl, II. Meşrutiyet döneminde siyasetten uzak kalan ender mecmualardan biridir. İşte bu sebepten dolayı 1. sayıdan 100. sayıya kadar başlığı hiç değişmemiştir. Meşrutiyet döneminin getirdiği aşırı basın hürriyeti içinde, kaba ve çirkin bir mizah anlayışını benimseyen gazete ve mecmualar, kısa sürelerde kapanıp başka isimler altında yeniden çıkarılmışlardır. Şehbâl dergisi böyle bir dönemde yayım hayatı süresince hiçbir takibata uğramadan 100. sayısını yayımlayabilmiştir." (Konuk, 2001: 9).

Dergi yüksek baskı kalitesi, sayfa ebatlarının büyüklüğü, basılı çok sayıdaki fotoğrafı ve bu fotoğraflarının baskı kalitesiyle dikkat çeker. Derginin baskı kalitesi için matrisleri İtalya'da hazırlanmıştır. Dergide Avrupa'dan getirilen "papier couche" kâğıdı kullanılmıștır. "Şehbâl'in sayfa düzeni ve baskı güzelliği yalnızca yurt içinde değil yurt dışında da takdir görmüş, 1911'de İtalya'nın Torino şehrinde düzenlenen fuarda dergiye altın madalya verilmiştir (No: 77, s. 95). 38 x 25 ebadında beyaz parlak kağıda (kuşe) basılıp kırılmaması için abonelere karton kutu içinde gönderilen Şehbâl 5 kuruştan satılmış, devrin bazı yayın organlarında (Sabah, No: 7052) bu fiyatın oldukça pahalı bulunduğu belirtilince dergide bunun ancak baskı masraflarını karşıladığı duyurulmuştur (No: 82). Her sayısı yirmi sayfa olan ve yirmi dört sayısı bir cilt teşkil eden derginin cilt kapakları deri ve bez olmak üzere Almanya'da yaptırılmıştır." (Polat, 2010: 424). İstanbul'un işgali esnasında derginin idârî binası yanmış ve koleksiyonları yok olmuştur (Öncel, 2010: 6).

\section{2. Şehbâl Dergisi (1909-1914) Tarafindan Düzenlenen On İki Kelime-i Ecnebiyeye Türkçede Mukâbil Bulmak Müsâbakası}

Türk basın tarihinde ilk müsabakanın kim tarafından düzenlendiği tam olarak belli değilse de Şehbâl dergisinin bu konuda öncü dergilerden olduğunu söylemek yanlış olmaz. Şehbâl dergisi tarafından düzenlenen ilk müsabaka, derginin 6. sayısında (1 Haziran 1325) düzenleneceği belirtilen fotoğraf, karikatür ve mûsikî müsabakalarıdır (Şehbâl, No: 6: s. 102). Şehbâl dergisi tarafından düzenlenen ikinci müsabaka dergisinin 36. sayısında düzenleneceği belirtilen 1. "Ayda, Karmen, Maskot" namlarındaki üç eser-i mûsikîden herhangi birinin güftesinin aslının veznine ve bestesine tevâfuk edecek sûrette, nazmen Türkçeye tercüme edilmesi. 2. Fransa muharrirîn-i felsefiyesinden Ribo (Ribot)'nun "Emrâz-ı Hâfıza, Emrâz-ı İrâde, Emrâz-ı Şahsiyet" isimlerindeki üç küçük eserinden herhangi birinin Türkçeye tercüme edilmesi. 3. Âtideki on iki kelime için Lisân-ı Osmânîde Mukâbiller (On iki Kelime-i Ecnebiyeye Türkçede Mukâbil Bulmak Müsâbakası) ihdâs ve ta'yin etmek müsabakalarıdır. Her iki müsabakada da müsabakaların düzenlenme amacı, müsabaka şartları ve müsabaka ile ne gibi sonuçlara ulaşıldığı gibi hususlara dergide yer verilmiștir (Şehbâl, No: 36: s. 222).

Aynı sayıda "Muhterem Kârî’lere" başlıklı yazıda "Şimdi de müsâbakalar ihdâsı hakkındaki va'dimizi icrâya sıra geldi. Tafsîlât-ı müsâbaka aşağıda görülecektir" denilmekte, yazının altında yer alan "Müsâbakalarımız" başlığı altında müsabakalar düzenleneceği ve bu müsabakalar ile ecnebî dillerden girip lisanımızda karşılığı bulunmayan bazı kelimelere karşılık bulmak, özellikle musiki ve tiyatro gibi sanat dallarına hayat verecek girişimlere meslek dâhilinde vasıta olmak, bu alanlarda birkaç eser yazılmasını kolaylaştırıp teşvik etmek yoluyla memlekete hizmet etmenin amaçlandığı belirtilmiştir. Dergide düzenlenecek ikinci müsabaka şu şekilde duyurulmuştur:

Birinci Müsâbaka: “Ayda, Karmen, Maskot” namlarındaki üç eser-i mûsikîden herhangi birinin güftesini aslının veznine ve bestesine tevâfuk edecek sûrette, nazmen Türkçeye tercüme etmek. Mükâfat 15 lira-i Osmânî

İkinci Müsâbaka: Fransa muharrirîn-i felsefiyesinden Ribo (Ribot)'nun "Emrâz-ı Hâfıza, Emrâz-ı İrâde, Emrâz-ı Şahsiyet" isimlerindeki üç küçük eserinden herhangi birini Türkçeye tercüme etmek. Mükâfat 10 lira-i Osmânî

\footnotetext{
${ }^{3}$ Şehbâl dergisindeki edebiyatla ilgili metinler üzerine Ahmet Ölmez tarafindan yüksek lisans tezi hazırlanmıştır. Bilgi için bkz. Ahmet Ölmez, Şehbal Mecmuası (inceleme ve edebiyatla ilgili metinler). Sivas: Cumhuriyet Üniversitesi Sosyal Bilimler Enstitüsü, Yüksek Lisans Tezi, 2018.
} 
Üçüncü Müsâbaka: Âtîdeki on iki kelime için Lisân-ı Osmânî’de Mukâbiller (On iki Kelime-i Ecnebiyeye Türkçede Mukâbil Bulmak Müsâbakası) ihdâs ve ta'yîn etmek. Mükâfâtı nakden 1 lira yâhûd risâlemizin bir senelik abonesi (Şehbâl, No: 36: s. 222).

Görüldüğü üzere ilk iki müsabaka için 15 Osmanlı lirası istenirken Lisân-ı Osmânîde Mukâbiller Müsâbakası (On iki Kelime-i Ecnebiyeye Türkçede Mukâbil Bulmak Müsâbakası) için verilecek ödüller 1 Osmanlı lirası olarak belirtilmiştir.

Şehbâl'de düzenlenen üçüncü için Lisân-ı Osmânîde Mukâbiller Müsâbakası isminin yanı sıra On iki Kelime-i Ecnebiyeye Türkçede Mukâbil Bulmak Müsâbakası ismi de kullanılmaktadır. Buna göre teklif edilecek kelimelerin Türkçe, Arapça ve Farsça olmasında bir sakınca yoktur. Teklif edilecek kelimelerin şaşılacak derece garip (absürt) olmamaları gerekir. Bununla birlikte teklif edilecek karşllıklar tek kelimeden veya tamlama şeklinde birden fazla kelimeden oluşabilir. Bu kelimelere en güzel karşılığı bulan kimse her bir kelime için dergiye bir ay ücretsiz abone edilecektir. Dolayısıyla 12 kelimenin 12'sine de doğru karşılık bulan kişi dergiye bir yıl ücretsiz abone edilecektir. İlk iki müsabaka için 15 Temmuz 1327 tarihine kadar (dört ay) ve üçüncü müsabaka için de 15 Nisan 1327 tarihine kadar (bir ay) süre verilmiştir. Gerekirse bu süre uzatılabilecektir. İlk iki müsabakada birinci olan kişilerin fotoğraflarına ve eserlerine Şehbâl dergisinde yer verilecektir. Müsabakalarla ilgili son söz dergi yönetiminde olacaktır. Yapılan duyuruda ayrıntılı bilgi için dergi yönetimine başvurulabileceği belirtilip dergiye gönderilen zarfların üzerine "müsâbaka" kelimesinin yazılması istenmektedir (Şehbâl, No: 36: s. 222).

Düzenlenen müsabakada karşllık bulunması teklif edilen kelimeler şunlardır: 1 . Bibliographie, 2. Boycottage, 3. Caprice, 4. Caricature, 5. Clup, 6. Conference, 7. Concert, 8. Decor, 9. Monologue, 10. Paradoxe, 11. Surprise, 12. Taximetre (Şehbâl, No: 36: s. 222).

Şehbâl dergisinin 38. sayısında (15 Nisan 1327) okuyucuların düzenlenen müsabakalara büyük bir alaka gösterdiği ve okuyuculardan bu konuda duyulan memnuniyeti ifade eden pek çok mektup alındığı dile getirilmektedir. Hatta dergiye "çok gazete okumayanlardan bir okuyucu" imzasıyla gönderilen yazıda "müsâbakalarınıza, daha doğrusu tarz-ı müsâbakayı ibrâ eden fikrinize âşılk oldum" denilmektedir. Dergi yönetimi kendilerine gönderilen ve teveccühü ifade eden bu yazılardan oldukça memnun olduklarını dile getirmekte; buna karşılık kendilerinin de doğru gördükleri bu yolda üzerlerine düşeni hakkıyla yapmaya çalışacaklarını ifade etmektedir. Dergi yönetimi ayrıca kendilerine sıkça sorulan "birinci ve ikinci müsâbakalarda tercümesi teklif edilen eserlerden hepsinin 'şâyân-ı kabûl bir sûretde' tercüme olunması" durumunda ne yapacakları sorusuna da cevap vermektedir. Dergi yönetimi böyle bir durumda izleyecekleri yolun çok basit olduğunu, böyle bir durumda tercümesi teklif edilen eserlerin hepsi için ayrı ayrı mükâfat vereceklerini belirtmektedir (Şehbâl, No: 38: s. 262).

Şehbâl dergisinin 39 numaralı sayısında (1 Mayıs 1327) On İki Kelimeye Mukâbiller Bulmak Müsâbakasının 15 Nisan tarihinde sona erdiği ve bu müsabakaya 518 kişinin bine yakın öneriyle katıldığı, bunların arasında bazı kadınların da bulunduğu belirtilip dergi yönetiminin bundan son derece memnun olduğu ifade edilmektedir (Şehbâl, No: 38: s. 282).

Şehbâl dergisinin 40. sayısında (15 Mayıs 1327) müsabakaları idare etmekten sorumlu müdür olan Jacque Sayabalyan Efendi'nin uzun bir seyahatte çıtı̆̆ından dolayı dergideki görevinden ayrıldığı belirtilmiştir. Ayrıca bu yazıda müsabakada dereceye girenlerin hangi ölçütlere göre seçildiği belirtilmiştir. Buna göre teklif edilen kelimeler oluşturulan heyet tarafından ayrı ayrı oylamaya sunulmuş, en çok oy alan kelimeler ayrılmış ve bu kelimelerin sahipleri arasından kura çekilmiştir. Bu yazıda On İki Kelime-i Ecnebiyeye Türkçede Mukabil Bulmak Müsâbakası'nın neticesine yer verilmiştir. Dergi, müsabakaya katılan 517 okuyucunun isimlerini neşretmeyi arzuladıklarını ancak dergide sayfa sınırlamasından dolayı bunu yapamayacaklarını ifade etmektedir. Derginin bu sayısında on iki kelime için kaç kişinin hangi kelimeleri teklif ettikleri yazılmıştır. Bu on iki kelimeye karşıllk teklif edilen kelimeler ve bu kelimelerin kaç kişi tarafından teklif edildiği aşağıda tablo halinde verilmiştir: (Şehbâl, No: 40: s. 302) 
Full Text Book

\begin{tabular}{|c|c|c|c|}
\hline $\begin{array}{l}\text { Sira } \\
\text { No. }\end{array}$ & $\begin{array}{l}\text { Müsabakada } \\
\text { Karşılık Bulması } \\
\text { İstenen Kelime }\end{array}$ & Teklif Edilen Kelime & $\begin{array}{l}\text { Teklif Eden } \\
\text { Sayısı }\end{array}$ \\
\hline \multirow{17}{*}{1} & \multirow{17}{*}{ Bibliographie } & 1. Mebhas-i kütüb & 63 \\
\hline & & 2. Kitâblar & 7 \\
\hline & & 3. Şerh-i ism-i kütüb & 1 \\
\hline & & 4. Kitâb-şinaslık & 2 \\
\hline & & 5. Kitâb-nâme & 1 \\
\hline & & 6. Ma'rifet-i kütüb & 121 \\
\hline & & 7. Kütüb-i münteșire & 35 \\
\hline & & 8. Fihrist-i âsâr & 94 \\
\hline & & 9. Tasnîf-i kütüb & 19 \\
\hline & & $\begin{array}{l}\text { 10. Mebhas-i ahvâl-i kütüb / } \\
\text { İlm-i ahvâl-i kütüb }\end{array}$ & 286 \\
\hline & & 11. Esâmi-i kütüb & 170 \\
\hline & & 12. Medârik-i kütüb & 18 \\
\hline & & 13. Merâci' & 11 \\
\hline & & 14. Câmi'-i âsâr & 6 \\
\hline & & 15. Tavsîf-i mü'ellefât & 103 \\
\hline & & 16. Fihrist-i te'lîfât & 61 \\
\hline & & 17. Tedkîk-i mü'ellefât & 60 \\
\hline \multirow{14}{*}{2} & \multirow{14}{*}{ Boycottage } & 1. Nebz-i iktisâdî & 52 \\
\hline & & 2. Nebz-i ticârî & 38 \\
\hline & & 3. Tecrîd & 21 \\
\hline & & 4. Mukâta'a & 267 \\
\hline & & 5. Memnû'iyet-i șirâ' & 83 \\
\hline & & 6. Tahrîm & 46 \\
\hline & & 7. Kat'-ı mu'âmele & 41 \\
\hline & & 8. Mukâsara & 2 \\
\hline & & 9. İstinkâfe & 1 \\
\hline & & 10. Hacr-ı millî & 5 \\
\hline & & 11. Harb-i iktisâdî & 384 \\
\hline & & 12. Bürîde & 1 \\
\hline & & 13. Küskünlük & 3 \\
\hline & & 14. Merdûdiyet & 7 \\
\hline \multirow{13}{*}{3} & \multirow{13}{*}{ Caprice } & 1. Hâcis & 8 \\
\hline & & 2. Heves & 713 \\
\hline & & 3. Nesnâsî, nesnâsiyet & 1 \\
\hline & & 4. Televvün & 94 \\
\hline & & $\begin{array}{l}\text { 5. Televvün-i edâ / } \\
\text { televvün-i mîzâc }\end{array}$ & 270 \\
\hline & & 6. Her-dem hayâlî & 1 \\
\hline & & 7. Keyf & 23 \\
\hline & & 8. Zevk-i selîm & 1 \\
\hline & & 9. Meymûn iștihâsı & 125 \\
\hline & & 10. Merâk & 33 \\
\hline & & 11. Hırçınlık & 7 \\
\hline & & 12. Hercâ'îlik & 14 \\
\hline & & 13. Densizlik & 1 \\
\hline \multirow{3}{*}{4} & \multirow{3}{*}{ Caricature } & 1. Nekre-tasvîr & 53 \\
\hline & & 2. Hicv-i resmî & 5 \\
\hline & & 3. Tasvîr-i hecâ'î / resm-i & 261 \\
\hline
\end{tabular}


III.International Congress of Language and Literature

\begin{tabular}{|c|c|c|c|}
\hline & & hecâ'î / resm-i hicvî & \\
\hline & & 4. Mudhike & 3 \\
\hline & & 5. Müstehzi'e & 2 \\
\hline & & 6. Resm-i mudhik & 109 \\
\hline & & 7. Tasvîr-i ma'nidâr & 42 \\
\hline & & 8. Resm-i mufazzih & 1 \\
\hline & & $\begin{array}{l}\text { 9. Resm-i istihzâ'î / Resm-i } \\
\text { müstehzî }\end{array}$ & 72 \\
\hline & & 10. Muzâha & 10 \\
\hline & & 11. Dihke & 6 \\
\hline & & 12. Tasvîr-i mudhik & 77 \\
\hline & & 13. Levh-i muhayyel & 1 \\
\hline & & 14. Levha-i hicv & 34 \\
\hline & & 15. Tehzîl & 1 \\
\hline & & 1. Mahfel & 261 \\
\hline & & 2. Müntedî & 60 \\
\hline & & 3. Mesbat & 1 \\
\hline & & 4. Mecma' & 102 \\
\hline 5 & Clun & 5. Dârü'l-ârifîn & 3 \\
\hline 5 & Clup & 6. Nâdî / nedve & 113 \\
\hline & & 7. Dernek & 85 \\
\hline & & 8. İçtimâgâh & 2 \\
\hline & & 9. Mecma'-i ihvân & 19 \\
\hline & & 10. Lonca & 52 \\
\hline & & 1. Eglenti & 210 \\
\hline & & 2. Âhenk & 46 \\
\hline & & 3. Dernek & 7 \\
\hline & & 4. Müsâmere & 92 \\
\hline & & 5. Müsâmere-i mûsîkiye & 125 \\
\hline & & 6. Bezm-i âhenk & 30 \\
\hline 6 & Concert & 7. Hafle-i mûsîkiye & 4 \\
\hline & & 8. Âhenk-i mûsîki & 1 \\
\hline & & 9. Hitâbe-i mûsîki & 2 \\
\hline & & 10. Cem'iyyet & 1 \\
\hline & & 11. Çalgl cem'iyeti & 19 \\
\hline & & 12. Mutribe & 3 \\
\hline & & 1. Hitâb, hitâbe & 208 \\
\hline & & 2. Hutbe & 82 \\
\hline & & 3. Müșâvere & 5 \\
\hline & & 4. Müdâvele & 16 \\
\hline 7 & Conference & 5. Muhâżara & 89 \\
\hline & & 6.Meclis-i mükâleme & 2 \\
\hline & & 7. Muhatabe & 1 \\
\hline & & 8. Mev'ize & 151 \\
\hline & & 9. Mû'temir & 24 \\
\hline & & 1. Tezyînât & 324 \\
\hline & & 2.Tezyînât-ı mer'iyye & 65 \\
\hline & & 3. Zînet & 112 \\
\hline 8 & Decor & 4. Müzeyyenât & 83 \\
\hline & & 5.Müzeyyenât-ı esâsiyye & 46 \\
\hline & & 6. Esâs-ı tezyîn & 3 \\
\hline & & 7. Hey'et-i mer'iyye & 21 \\
\hline
\end{tabular}


Full Text Book

\begin{tabular}{|c|c|c|c|}
\hline & & 8. Süs & 95 \\
\hline & & 9. Bezek & 18 \\
\hline & & 10. Hâne-i zîbâ & 1 \\
\hline & & 11. Tecemmülât & 35 \\
\hline & & 12. Donanma & 6 \\
\hline & & 13. Pîrâye & 1 \\
\hline & & 14. Nigâr & 2 \\
\hline \multirow{11}{*}{9} & \multirow{11}{*}{ Monologue } & 1. Söylenme & 146 \\
\hline & & 2. Söyleniş & 301 \\
\hline & & 3. Hasbihâl & 222 \\
\hline & & 4. Bast-ı hâl & 1 \\
\hline & & 5. Hod-gû & 12 \\
\hline & & 6. Vesvese & 1 \\
\hline & & 7. Nutk-ı meddâh & 1 \\
\hline & & 8. Kelîm & 4 \\
\hline & & 9. Mütekellim-i vâhde & 7 \\
\hline & & 10. Hicrâs & 1 \\
\hline & & 11. Tekâlüm & 1 \\
\hline \multirow{14}{*}{10} & \multirow{14}{*}{ Paradoxe } & 1. Garîbe & 52 \\
\hline & & 2. 'Acîbe & 19 \\
\hline & & 3. Garâbet-i fikr & 11 \\
\hline & & 4. U'cûbe & 70 \\
\hline & & 5. Nâdire & 72 \\
\hline & & 6. Fâze & 2 \\
\hline & & 7. Müfâd-ı mestûr & 1 \\
\hline & & 8. Tebâyün & 1 \\
\hline & & 9. Havârık & 1 \\
\hline & & 10.Da'vâ-yı mücerred & 409 \\
\hline & & 11. Hark-ı müsellem & 2 \\
\hline & & 12. Hârika & 4 \\
\hline & & 13. Bed'et & 1 \\
\hline & & 14. Bedâ'et & 1 \\
\hline \multirow{14}{*}{11} & \multirow{14}{*}{ Surprise } & 1. Baskın & 183 \\
\hline & & 2. Mugâbasa & 1 \\
\hline & & 3. Hayret & 145 \\
\hline & & 4. Füc'e & 27 \\
\hline & & 5. Bağte & 1 \\
\hline & & 6. Tahyîr & 23 \\
\hline & & 7. Şașırtma & 283 \\
\hline & & 8. Muğfele & 82 \\
\hline & & 9. Nâ-be-hengâm & 1 \\
\hline & & 10. Muhayyire & 5 \\
\hline & & 11. Yakalanma & 64 \\
\hline & & 12.Tesâdüf-i gayr-ı muntazır & 9 \\
\hline & & 13. Nâ-gehres & 1 \\
\hline & & 14. Mufâce'e & 1 \\
\hline \multirow{6}{*}{12} & \multirow{6}{*}{ Taximetre } & 1. Mikdâr-nâme & 3 \\
\hline & & 2. Narh-nümâ & 14 \\
\hline & & 3. Mikyâs-ı mikdâr & 7 \\
\hline & & 4. Ücret-nümâ & 401 \\
\hline & & 5. Râh-peymâ & 2 \\
\hline & & 6. Narh & 1 \\
\hline
\end{tabular}




\begin{tabular}{|l|l|l|}
\hline \multirow{3}{*}{} & 7. Para saati & 8 \\
\cline { 2 - 3 } & 8. Mikyâs-i fey' & 3 \\
\hline & 9. Mîzân-ı mesâfe & 252 \\
\cline { 2 - 3 } & 10. Mesâfe-nüvîs & 138 \\
\hline & 11. Reh-peymâ & 1 \\
\hline
\end{tabular}

Tablo 1: Müsabakada karşılık bulunması istenen kelimeler ve buna karşılık teklif edilen kelimeleri gösterir liste (Şehbâl, No: 40, s. 302).

Müsabakada karşıllk bulunması istenen kelimelerden üç tanesi Türk Dil Kurumu tarafından basılan Yabancı Sözlere Karşıllklar Kılavuzunda yer almakta olup diğer kelimelere bir karşılık önerilmemiștir. Türk Dil Kurumu tarafından basılan bu kllavuzda Bibliographie kelimesine karşılık "kaynakça" (YSKK, 2008: 29), Paradoxe kelimesine karşılık "1. Aykırı düşünce 2. Çelişki" (YSKK, 2008: 90), Surprise kelimesine karşllı "şaşırtı" (YSKK, 2008: 115) kelimesi önerilmiştir. Bu kelimelerden Bibliographie kelimesine karşıllk olarak önerilen "kaynakça" (YSKK, 2008: 29) kelimesi Paradoxe kelimesine karşılık olarak önerilen "1. Aykırı düşünce 2. Çelişki" (YSKK, 2008: 90) kelimeleri standart Türkiye Türkçesinde yaygın olarak kullanılmaktadır.

Şehbâl dergisinin 40. sayısında müsabakaya teklif edilip kabul edilen kelimelere yer verilmiștir. Düzenlenen müsabakada dereceye giren bazı kelimelere karşılık olarak birden fazla kelimenin kabul edildiği görülmektedir: "Bibliographie" kelimesi için kitâb-nâme, kitâb-şinâsî, kitâbşinaslık; "boycottage" kelimesi için mukâta'a, mukâsara; "monologue" kelimesi için hasbihâl, söyleniş, tekâlüm; "taximetre" kelimesi için para saati, ücret-nümâ, mesâfe-nüvis kelimeleri kabul edilmiştir. Ancak "caricature" kelimesine karşıllk hangi kelimenin kabul edildiğine dair bir bilgi bulunmamaktadır. Müsabakada dereceye giren kelimeler aşağıda tablo halinde verilmiştir.

Tablo 2: Müsabakada dereceye giren kelimeler (Şehbâl, No: 40, s. 302)

\begin{tabular}{|l|l|l|}
\hline $\begin{array}{l}\text { Sira } \\
\text { No. }\end{array}$ & $\begin{array}{l}\text { Karşılık Bulması } \\
\text { İstenen Kelime }\end{array}$ & Teklif Edilip Kabul Edilen Kelime(ler) \\
\hline 1 & Bibliographie & $\begin{array}{l}\text { Kitâb-nâme, kitâb-şinâsî (Bu kelime teklif edilen } \\
\text { kelime listesinde bulunmamaktadır), kitâb-șinâslık }\end{array}$ \\
\hline 2 & Boycottage & Mukâta'a, mukâsara \\
\hline 3 & Caprice & Merâk \\
\hline 4 & Caricature & (karşlık yazılmamış) \\
\hline 5 & Club & Mahfel \\
\hline 6 & Concert & Mutribe \\
\hline 7 & Conference & Hitâbe, mev'ize \\
\hline 8 & Decor & Nigâr \\
\hline 9 & Monologue & Hasbihâl, söyleniş, tekâlüm \\
\hline 10 & Paradoxe & Bedâ'et \\
\hline 11 & Surprise & Mufâce'e \\
\hline 12 & Taximetre & Para saati, ücret-nümâ, mesâfe-nüvîs \\
\hline
\end{tabular}

Müsabakaya o dönem Osmanlı coğrafyasında yer alan farklı yerlerden kişiler katılmışlardır. Kelime teklifinde bulunan dokuz isimden üçü İstanbul'dan, biri Mekke'den, biri İzmir'den, biri de Siroz'dan (Serez) müsabakaya katılmışlardır. Müsabakada dereceye girenlerden biri doktordur, birinin de Mekteb-i Tıbbiye-i Mülkiye'den olduğu belirtilip unvanına yer verilmemiștir. Müsabakada dereceye girenlerden biri Nişantaşı'nda 'Afîfe Sâre Hanım adında bir kadındır, diğerleri ise erkektir. Müsabakada dereceye giren kelimelerin kimler tarafından teklif edildiği aşağıda tablo halinde verilmiştir.

\begin{tabular}{|l|l|l|l|}
\hline $\begin{array}{l}\text { Sıra } \\
\text { No. }\end{array}$ & Teklif Eden & $\begin{array}{l}\text { Kelime } \\
\text { Sayısı }\end{array}$ & Teklif Ettiği Kelime(ler) \\
\hline 1 & $\begin{array}{l}\text { Mekteb-i Tıbbiye-i Mülkiye'den M. N. } \\
\text { D. Bey }\end{array}$ & 2 & mukâta‘a, kitâb-şinâslık \\
\hline 2 & Nişantaşı'nda 'Afîfe Sâre Hanım & 3 & kitâb-nâme, hitâbe, \\
\hline
\end{tabular}




\begin{tabular}{|l|l|l|l|}
\hline & \multicolumn{1}{|c|}{} & hasbihâl \\
\hline 3 & Doktor Fu'âd Sâbit Bey & 2 & söyleniş, mahfel \\
\hline 4 & Hasan İrfan Bey & 1 & Mesâfe-nüvîs \\
\hline 5 & $\begin{array}{l}\text { Mekke-i Mükerreme'de Mehmed } \\
\text { Sâlim Bey }\end{array}$ & 3 & $\begin{array}{l}\text { mutribe, } \\
\text { mukâsara }\end{array}$ \\
\hline 6 & Üsküdar'da Ali İlmîney'e, Bey & 2 & nigâr, tekâlüm \\
\hline 7 & Siroz'dan H.D Bey & 3 & bedâ'et, merâk, mev'ize \\
\hline 8 & İzmir'de Mustafa Hâmid Bey & 1 & para saati \\
\hline 9 & Nâzım Bey & 1 & ücret-nümâ \\
\hline
\end{tabular}

Tablo 3: Müsabakada dereceye giren kişiler ve bu kişilerin teklif ettiği kelimeler (Şehbâl, No: 40, s. 302)

Şehbâl dergisinin düzenlediği müsabaka için çeşitli kurallar belirlemiştir: Buna göre karşıllk olarak teklif edilecek kelimelerin Türkçe, Arapça ve Farsça olmasında bir sakınca yoktur. Teklif edilecek kelimelerin şaşılacak derece garip (absürt) olmamaları gerekir. Bununla birlikte teklif edilecek kelimeler tek kelimeden veya tamlama şeklinde birkaç kelimeden oluşabilir (Şehbâl, No: 38, s. 262). Müsabakada teklif edilen kelimeler kökenlerine göre incelen diğinde karşımıza şöyle bir tablo çıkmaktadır:

\begin{tabular}{|c|c|c|c|c|c|c|c|c|c|}
\hline Kelime & $\begin{array}{l}\text { Önerile } \\
\mathrm{n} \\
\text { Kelime } \\
\text { Sayısı }\end{array}$ & 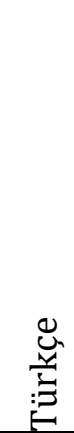 & 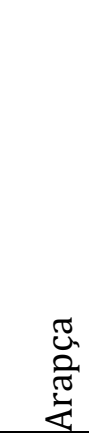 & 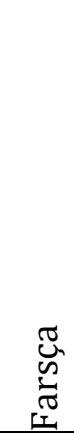 & 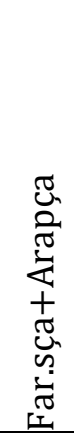 & 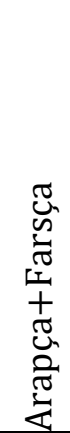 & 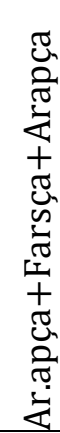 & 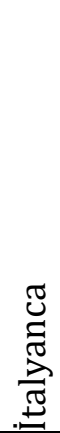 & 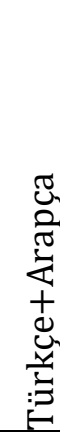 \\
\hline Bibliographie & 17 & & 15 & & 2 & & & & \\
\hline Boycottage & 14 & 1 & 13 & & & & & & \\
\hline Caprice & 13 & 2 & 9 & 1 & 1 & & & & \\
\hline Caricature & 16 & & 14 & & & 1 & 1 & & \\
\hline Clup & 10 & 1 & 8 & & & & & 1 & \\
\hline Concert & 12 & 2 & 6 & 2 & 1 & & & & 1 \\
\hline Conference & 9 & & 9 & & & & & & \\
\hline Decor & 14 & 3 & 8 & 3 & & & & & \\
\hline Monologue & 11 & 2 & 8 & 1 & & & & & \\
\hline Paradoxe & 14 & & 14 & & & & & & \\
\hline Surprise & 14 & 3 & 10 & 1 & & & & & \\
\hline Taximetre & 11 & & 6 & 4 & 1 & & & & \\
\hline Toplam & 155 & 14 & 120 & 12 & 5 & 1 & 1 & 1 & 1 \\
\hline
\end{tabular}

Tabloya göre 155 kelimenin 120'si Arapça, 14'ü Türkçe, 12'si Farsça, 9'u da karma kelimelerden oluşmaktadır.

\section{SONUÇ}

Şehbâl dergisinin 36. sayısında duyurulan (15 Mart 1910) On iki Kelime-i Ecnebiyeye Türkçede Mukâbil Bulmak Müsâbakası Türkçe üzerinde ecnebî dillerin tesiri ile bu tesire karşı oluşan bilinç ve gösterilen direnci göstermektedir. Bu müsabakanın bir edebiyat dergisi tarafından değil de günlük konuları işleyen bir dergi tarafından düzenlenmiş olması ecnebî dillerden dilimize giren kelimelerden duyulan hoşnutsuzluğu göstermesi açısından önemlidir. 
Müsabakada kelime-i ecnebiye ile Batı dillerinden giren kelimeler kastedilmiş, Arapça ve Farsça gibi diller hariç tutulmuştur. Buna rağmen dergi yönetimi tarafından kurulan komisyon tarafından kabul edilen kelimelerden birinin İtalyanca olması dikkat çekicidir. Müsabakada komisyon tarafından dereceye giren kelimelerin hiçbiri karşılık bulunması istenen kelime yerine standart Türkiye Türkçesinde kullanılmamaktadır. Bunun başlıca sebeplerinden biri dilde sadeleşmenin ve yabancı kökenli kelimelere karşılık Türkçe kelimelerin kullanılmasının tartışıldığı bir dönemde önerilen kelimelerin çoğunluğunun yabancı kökenli, özellikle Arapça ve Farsça kökenli olması gelmektedir.

\section{KAYNAKÇA}

Ahmetoğlu, Selim (2007). From the Unıonıst Actualıté to the Mass Popularıty: Şehbâl (1909 1914). Yayımlanmamış yüksek lisans tezi, Boğaziçi Üniversitesi, İstanbul.

Ahmetoğlu, Selim (2010). Şehbal Mecmuası (1909-1914) İttihatçı Aktüaliteden Kitlesel Popülariteye. İstanbul: Libra Kitap.

Konuk, Neval (2001). Şehbâl Mecmuası'ndaki Sanat Tarihi Yazıları. Yayımlanmamış yüksek lisans tezi, Marmara Üniversitesi Sosyal Bilimler Enstitüsü, İstanbul.

Ölmez, Ahmet (2018). Şehbal Mecmuası (İnceleme ve Edebiyatla İlgili Metinler). Yayımlanmamış yüksek lisans tezi, Cumhuriyet Üniversitesi Sosyal Bilimler Enstitüsü, Sivas.

Öncel, Mehmet (2010). Rauf Yektâ Bey'in Âti, Yeni Mecmûa, Resimli Kitap ve Şehbâl Adlı Mecmûalarda Mûsikî ile İlgili Makalelerinin İncelenmesi, Yayımlanmamış yüksek lisans tezi, Marmara Üniversitesi, Sosyal Bilimler Enstitüsü, İstanbul.

Polat, Nazım H. (2010). Şehbâl. Türkiye Diyanet Vakfı İslam Ansiklopedisi. C. 38, s. 423-424. İstanbul: Türkiye Diyanet Vakfı Yayınevi.

Şehbâl Dergisi, No: 36, 15 Mart 1327

Şehbâl Dergisi, No: 38, 15 Nisan 1327

Şehbâl Dergisi, No: 39, 1 Mayıs 1327

Şehbâl Dergisi, No: 40, 15 Mayıs 1327

Şehbâl Dergisi, No: 41, 15 Temmuz 1327

Akalın, Şükrü Haluk, Toparlı, Recep, Tezcan Aksu, Belgin, Gültekin, Beyza \& Terzi, Adem (2008).

Yabancı Sözlere Karşılıklar Kılavuzu. Ankara: Türk Dil Kurumu Yayınları. 
AN INVESTIGATION ON NECIP FAZIL KISAKÜREK'S POEMS WITHIN THE CONTEXT OF PSYCHOANALYTIC THEORY OF LITERATURE

Mustafa KARABULUT 


\title{
AN INVESTIGATION ON NECIP FAZIL KISAKÜREK'S POEMS WITHIN THE CONTEXT OF PSYCHOANALYTIC THEORY OF LITERATURE
}

\author{
Mustafa KARABULUT ${ }^{1}$
}

\begin{abstract}
:
Psychoanalysis is a branch of science that focuses on the subconscious and unconscious aspects of human beings. "When it comes to the human soul, it is seen that almost the entire human ego is based on psychology." (Emre, 2006: 16). The psychoanalytic literary theory is a theory that tries to reveal the unconscious and subconscious aspects of the artist in general, and is shaped on the theories of Sigmund Freud. This theory has a feature that reflects the bonds between the identity of the artist and his work. "Until Freud, the origin of human behavior was generally associated with physiology. After long studies, Freud reveals that the unconscious is as effective as physiological conditions and disorders on the basis of human behavior. (Cebeci, 2009: 72). Necip Fazıl Kisakürek, one of the important names of Turkish poetry in the Republican period, is generally known for his mystical and metaphysical poems. There are many uses in his poems that are suitable for psychoanalytic analysis. In the poems of Kisakürek, "subconscious and image, rebirth, sense of emptiness, self-complexity, struggle for existence" etc. elements are included.
\end{abstract}

Key words: Necip Fazll Kısakürek, Literary theory, Psychoanalytic.

http://dx.doi.org/10.47832/Lan.con3-5

${ }^{1}$ Adıyaman University, Türkiye, $\underline{\text { mkarabulut@adiyaman.edu.tr }}$ 


\section{PSIKKANALİTIK EDEBIYAT KURAMI BAĞLAMINDA NECİP FAZIL KISAKÜREK'İN ŞİiRLERİ ÜZERINNE BİR İNCELEME}

\section{Öz:}

Psikanaliz, insanın bilinçaltı ve bilinçdışı yönleri üzerine yoğunlaşan bilim dalıdır. "İnsan ruhu söz konusu edildiğinde, aslında insan beninin neredeyse tamamının psikoloji üzerine kurulduğu görülür." (Emre, 2006: 16). Psikanalitik edebiyat kuramı, sanatçının genel olarak bilinçdışı ve bilinçaltı yönlerini açığa çıkarmaya çalışan bir kuram olup, Sigmund Freud'un teorileri üzerine şekillenmiştir. Bu kuram, sanatçının kimliği ile eseri arasındaki bağları dışa yansıtan bir özellik taşır. “Freud'a kadar insan davranışlarının kökeni genel olarak fizyolojiyle ilişkilendirilmekteydi. Uzun çalışmalardan sonra Freud, insan davranışlarının temelinde fizyolojik durum ve rahatsızlıklar kadar, bilinçdışının da etkili olduğunu ortaya çıkarır. (Cebeci, 2009: 72). Cumhuriyet dönemi Türk şiirinin önemli isimlerinden olan Necip Fazıl Kısakürek, genel olarak mistik ve metafizik şiirleriyle tanınır. Onun şiirlerinde psikanalitik bakımdan irdelenmeye uygun birçok kullanım vardır. Kısakürek'in şiirlerinde psikanalitik açıdan "bilinçaltı ve imge, yeniden doğuş, boşluk duygusu, benlik karmaşası, var oluş mücadelesi” vb. unsurlar yer alır.

Anahtar Kelimeler: Necip Fazıl Kısakürek, Literary theory, Psychoanalytic.

\section{Psikanalitik Edebiyat Kuramına Dair Bazı Tespitler}

Psikanalitik edebiyat kuramı, psikanalizin sanatçı ve eserine uygulanması ile ortaya çıkan bir kuram olup sanatçının kimliği ile yapıtı arasındaki bağı dışa yansıtan özellik taşır. Bu kuram, 'Psikanalitik edebiyat kuramı sanatçının 'kimliği' ve yapıtının 'ne' olduğu konusunda bir 'iç' bakışı gerçekleştirmek için, Freud'un öncülüğünde keşfedilen ve daha sonraki psikanaliz ekollerinin geliştirdiği kavramları, özellikle de bilinçaltının çalışmasına ilişkin ilkeleri kullanır." (Karabulut, 2019a: 193). Burada sanatçı ile eseri arasındaki ilişki psikanalizin ilgilendiği yapılar kullanılarak artaya konulmaya çalışılır. Edebiyat eserinin temel taşı olan "kelime", psikanaliz için de çok önemlidir.

Freud, "söz bir insanın bir başkasını etkilemede başvurduğu en önemli çare, söylendiği kimsede ruhsal değişikliklere yol açma bakımından eşi bulunmaz bir araçtır." (Freud, 1998) diyerek psikoloji, dil ve edebiyat arasındaki ilişkiye dikkat çeker. Psikanalistler yaratma eylemini psikolojik bir etkinlik şeklinde algıladıkları için sanatçı ile eseri arasında ilişki olduğunu dile getirirler. "Psikanaliz sanatçının bilinçaltına inerek eserin neden ve nasıl yazıldığını inceler." (Karabulut, 2011: 974).

Terry Eagleton, psikanalitik eleştirilerin çoğunun aslında en sınırlı ve en sorunlu olan yaza ve içerik olarak iki türde meydana geldiğini dile getirir. Eaglaton, bu denemelerin ya eserde kendini açığa çıkardığı kadarıyla yazarın psikanalitik açıklamasını yapacağını ya da hayatta takip edilebilecek bir şekilde bilinçdışının sanat eserindeki semptomlarını inceleyeceğini ifade eder. (Eaglaton, 2011: 187).

Psikanalitik edebiyat incelemelerinde "arketipsel eleștiri", önemli yere sahiptir. Bu eleștiri yönteminde, edebi eserlerdeki imgelerin psikolojik ve mitolojik kökenlerine inilmeye çalışılır. Bu bakış açısını psikolojik açıdan öne çıkaran Carl Gustav Jung'dur. Jung'un kurduğu "analitik psikoloji" ile bireyin psikolojik dünyasını "bilinçli" ve "bilinçdışı" olarak iki kısma ayrır. Jung, büyük önem verdiği bilinçdışını "bireysel bilinçdışı" ve "kolektif bilinçdışı" olarak ikiye ayırarak psikanalitik tahliller yapar. Jung, "bireysel bilinçdışı"nda bastırılmış dürtülerin ve çocukluk özlemlerinin ağırlıkta olduğunu; "kolektif bilinçdışı"nda ise "ilkimge" olarak ifade ettiği arketiplerin yer aldığını (Jung, 2013: 20) söyler. 
Psikanalitik edebiyat kuramı; sanatçıdan esere, eserden sanatçıya ve esere yönelik olmak üzere üç kısımda ele alınır. Sanatçıdan esere (sanatçının psikolojisi, kişiliği, eseri) psikanalitik kuramda yazarın çocukluğu, ruhsal durumu, bilinçaltı, tercihleri, cinsel yapısı vb. yönlerinin edebi eser üzerindeki yansımasına bakılır. "Psikanaliz verileri sadece yazarın kişiliği ile değil onun eserlerinde yarattığı tip ve karakterlerle de ilgilenir. Gerçek bir kişilik gibi bir kahramanın psikanalitik tahlili yapılır." (Kolcu, 2008: 199).

Sanatçılar, algı, duyuş ve ifade ediş bakımlarından genel olarak diğer insanlardan farklılık gösterirler. Freud, sanatçlların kendine has bir his ve ifade yönü olduğunu söyler.2 Bu bakımdan onun sevinçlerinde olduğu kadar acılarını açığa çıkarmada da farklılık gösterdiğini belirtmek gerekir. "Yazar örnek bir çilekeştir, çünkü hem acı çekmenin en derin katmanlarına inmiş, hem de acısını yüceltmede profesyonel bir yöntem keşfetmiştir. Yazar, bir insan olarak acı çeker; yazar olarak da bu acısını sanata dönüştürür." (Sontag, 199: 131). Eserden sanatçıya psikanalitik kuramda ise karakter ve kişiliğin açığa çıkarılmasında eserden hareketl edilir. Burada, eserin incelenmesi sürecinde sanatçının bir figür olarak metinde bulunup bulunmadığını irdeleme anlaşılır. Esere yönelik psikanalitik kuramda ise metindeki kişilerin psikanalitik unsurlar içerisinde çözümlenmesi öne çıkar.

\section{Necip Fazıl Kısakürek'in Şiirlerine Psikanalitik Bir Bakş̧}

Necip Fazıl, ilk şiirlerinden itibaren psikolojik ve felsefi yönü olan dizeler de kaleme almaya başlar. "Örümcek Ağı, Çan Sesi, Kaldırımlar, Nefs, Bendedir gibi ilk kalem ürünlerinden başlayarak onun şiirlerini korku, ürperti, vehim, yalnızlık, boşluk, ölüm gibi öznenin varlığını tehdit eden temalar kaplar. Bunda rol oynayan başlıca etken, öznenin varlıkla, evrenle ve kendisiyle uyumlu bir iletişim ağı ve buna bağlı yaşama alanı kuramamasıdır." (Gariper, 2014: 120). Bu bağlamda Kısakürek'in şiirlerinde psikanalitik yönden "yeniden doğuş, bilinçaltı ve imge dünyası, yalnızlık, yabancılaşma, depresyon ve benlik arayışı" gibi hususların bulunduğunu belirtmek gerekir.

\subsection{Yeniden Doğuş Arketipi}

Yeniden doğuş, bireyin ruhsal bakımdan adeta yeniden dünyaya gelmiş olması anlamına gelir. Bunu arketip kuramı bağlamında temellendiren Carl Gustav Jung, yeniden doğuşu kahramanın yolculuğu ile ilişkilendirir. "Jung yeniden doğuş arketipini temel alarak bireyleşme süreciyle, kahramanın yaptığı gece deniz yolculuğunun arketipsel imgesi arasında bir benzerlik kurar." (Korucu, 2019: 711).

Necip Fazıl, 1934'te Seyyid Abdülhakim Arvâsî Efendi ile karşllaştıktan sonra ruhsal manada büyük değişimler gösterir. Onun dönüşümü, analitik psikolojinin kurucusu Jung'un arketip kuramına göre irdelenebilir. Jung, "kolektif bilinçaltı" olarak adlandırdığı insan zihninin bir bölgesinde çeşitli arketiplerin bulunduğu ve bu arketiplerin insan yaşamının her alanında yeniden üretildiğini dile getirir. (Güngör, 2015: 155). Jung, kişinin hayatını şekillendiren arketiplerden birisi olarak buna "yeniden doğuş arketipi" der. Abdülhakim Arvâsî ile tanışan şair adeta yeniden doğar.

Kısakürek, "eserleriyle çilesini, çilesiyle de eserlerini mayalamaya çalışmıştır." (Taşdelen, 2005). Şairin, "Çile" şiirinde adeta yeniden doğuşun hikayesini anlatır. Şairin iç dünyasındaki med-cezirler, çalkantılar, boşluklar ile benliğini kurma, var oluş mücadelesi arasındaki çatışmalar, onun üslûbunun oluşmasında en önemli etkilerdendir. (Karabulut, 2012).

\footnotetext{
${ }^{2}$ Freud'un sanatçılar ve eserleri ile analizleri ile ilgili tespitleri için şu kaynağa bakılabilir: Sigmund Freud, Sanat ve Sanatçılar Üzerine, çev. Kâmuran Şipal, Yapı Kredi Yayınları, İstanbul 2012.
} 
Aylarca gezindim, yıkık ve şaşkın,

Benliğim bir kazan ve aklım kepçe.

Deliler köyünden bir menzil aşkın,

Her fikir içimde bir çift kelepçe. (s.17)3

"Çile" adlı şiir Necip Fazıl'ın metafizik ürpertilerini ve mutlak hakikati arayışını dile getirir. 'Şiir ilk dizelerinden itibaren 'yüce' karşısındaki konumlanma kendini hissettirir. Şairin duyduğu sesin gaiblerden geliyor olması şairin kendinden menkul değerler oluşturmak isteğinde olmadığını öteden gelen bir sesi aktarma görevini üstlendiğini anlatır niteliktedir. Gaiblerden gelen ses, Necip Fazıl'ın yücelik karşısındaki tavrının öncelikle bir kulluk bilinci ile açımlandığını gösterir." (Hüküm, 2013: 48).

Gâiblerden bir ses geldi: Bu adam,

Gezdirsin boşluğu ense kökünde!

Ve uçtu tepemden birdenbire dam;

Gök devrildi, künde üstüne künde... (s.16)

Necip Fazıl, "Çile" şiirinde tasavvufun da etkisiyle yaşadığı iç değişimi dile getirir. Bu değişim, psikanalitik bakışta, bireyin iç dünyasındaki çatışmaların ve met cezirlerin sonucu olarak, kimlik oluşumu sürecini hatırlatır. Zamanı sorgulayan birey, saatin üzerindeki akrep ve yelkovanın hareketini zamanın raksı olarak algılar. "Zaman ile ilgili sorudan sonra kendi sonunu söz konusu etmesi; zaman ile son arasındaki ilişkiyi gösterir. Burada dikkat çekici olan; şairin, bu son sebebiyle korkmak ve acı çekmek yerine, bunun anlamını öğrenmeye çalışmasıdır. Böylece şairin metafizik endişeden, metafizik bir anlam alanına geçtiğini görüyoruz." (Yuva, 2009: 1695). Necip Fazıl'ı yoğuran, olgunlaştıran; en önemli unsur onun "çile"sidir. "Necip Fazıl'ın ruh dünyasında derin bir acı ve ıstıraba kaynaklık ederek şiirine yansıyan fikir, diyanet ve cemiyet olmak üzere iki farklı mecrada tezahür eder. (Erol, 2014: 66). Psikanalitik edebiyat kuramı açısından bakıldığında "Çile" adlı şiirde anlatıcının varlık-yokluk trajedisinde kimlik arayışı içerisinde olduğu görülür.

Kısakürek'in "Tam Otuz Yıl” adlı şiirde otuz yıl saatinin çalıştığını ancak kendisinin durduğunu söyleyen şair, adeta bir "yeniden doğuş"u dile getirir:

Tam otuz yll saatim işlemiş ben durmuşum;

Gökyüzünden habersiz uçurtma uçurmuşum. (s.35)

Kısakürek'in "Muhasebe" adlı şiirinde "yeniden doğuş" arketipinin yansımalarını görmek mümkündür. Bu şiirde anlatılanlar adeta yeni bir nesle (Büyük Doğu nesli) bir çağrıdır. Şair, şiirin ilk mısralarında bu durumu şöyle ifade eder:

Ben artık ne şairim, ne fıkra muharriri!

Sadece beyni zonklayanlardan biri!

Bakmayın tozduğuma meşhur Baballi'de!

Bulmuşum rahatımı ben bir tesellide.

Fikrin ne fahişesi oldum, ne zamparası!

Bir vicdanın, bilemem, kaçtır hava parası?

Evet, kafam çatlıyor, güya ulvi hastalık;

Bendedir, duymadığı dertlerle kalabalık.

Büyük meydana düştüm, uçtu fildişi kulem;

\footnotetext{
${ }^{3}$ Şiir alıntıları Necip Fazıl Kısakürek'in Çile adı kitabından yapılmıştır. Şiir alıntılarında sadece sayfa numarası verilecektir. Eserin tam künyesi için bkz. Kaynakça.
} 


\section{III.International Congress of Language and Literature}

Milyonlarca ayağın altında kaldı kellem... (s.402-403)

Erich Fromm, her insanın kendini adayabileceği bir nesnesin ve davranışlarına yön verecek bir düşünsel sistemin ihtiyacı içinde olduğunu ifade eder. (Fromm, 1991: 45). Necip Fazıl, ilk gençlik senelerinde içine düştüğü bunaltı ruh halinden kurtularak İslam'a sıkı sıkıya yönelir. 0, artık peşinden koştuğu, dini, milli, manevi idealleri için çabalayan biridir. Kısakürek, inanmış bir kişi olarak ikileme düşmez. (Karabulut, 2019b: 236). Bu onun "Allah'a tam bir teslimiyet" içerisinde olduğunu ifade etmesiyle yakından ilgilidir.

\subsection{Yalnızlık, Yabancllaşma ve Depresyon}

Psikanalizde bireyi depresyona sürükleyen birçok sebepten bahsedilir. Maddi ve manevi kayıplarla beraber, yalnızlık, yabancılaşma ve ötekileşme de buna eklenebilir. Psikiyatride depresyon ifadesi üç farklı anlamda verilir. "Terimin ilk kullanımı normal bireylerde de bir kayıp sonrası ortaya çıkabilen bir duygusal yaşantı olarak üzüntülü ve kederli ruh halini anlatır. Terimin ikinci kullanımı bir ruhsal belirti olarak depresyondur. Depresyonun üçüncü kullanımı ise özgül bir ruhsal rahatsızlığı anlatmak içindir." (Türkçapar, 2004: 12).

Kısakürek, "Otel Odaları" başlıklı şiirde depresif ruh hali içerisindeki bireyin psikolojisini mekân-insan ruhu ilişkisinden yola çıkarak dile getirir. Şair, bu şiirde "Otel odasında yer alan her nesne aslında şairin içinde bulunduğu ruh halinin, psikolojik durumun şekil bulmuş halidir. Şair nesnelerden hareketle içinde bulunduğu bohem havayı aksettirmeye çalışmıştır." (Yılmaz, 2014: 180).

Bir merhamettir yanan, daracık odaların,

İsli lâmbalarında, isli lâmbalarında. (s.161)

Yukarıdaki mısralarda isli lambaları merhamet bağlamında irdeleyen şair, yalnızlığın psikozunu derinden hisseden bireyin dar ve kasvetli mekândaki çıkışsızlığını irdeler. Şiirin anlatıcısı dar mekânın kaotik yapısı içerisinde patolojik bir yapı göstermektedir. Bu bakımdan şairin ruh hali ile mekân arasında yakınlık olduğunu söylemek mümkündür.

Gelip geçen her yüzden gizli bir akis kalmış,

Küflü aynalarında, küflü aynalarında. (s.161)

Yukarıdaki dizelerde geçen "küflü ayna" ifadesi şairin bilinçaltındaki korkuları, tedirginlikleri ve olumsuz çağrışımları karşılar.

Atılan elbiseler, boğazlanmış bir adam,

Kırık masalarında, kırık masalarında. (s.161)

Yukarıdaki beyit psikanalitik açıdan ele alındığında şiirin anlatıcısında bir psikoz hali olduğu görülür. Burada birey, anılara gömülmüş, yalnızlaşmış, yabancılaşmıș, iç ve dış çatışmalar yaşayan bir yapıdadır. (Karabulut, 2019b: 238). Burada psikanalitik bağlamda bireyin algı dünyasındaki kaotik yapı ön plana çıkar. "Bu mekânda bohemliği bütün yoğunluğuyla yaşayan özne, kasvetli odanın kırık masalarında dağınık bir şekilde duran elbiseleri boğazlanmış bir adam görüntüsüyle algılamıștır." (Sağlam, 2014: 249). Otel odasında yalnızlık ve kimsesizliğin bunaltısıyla depresyona giren birey, bilinçaltındaki tedirginlikleri ve ruhundaki yaraları duvardaki çivi yaraları şeklinde açığa çıkarır:

Atıyor sızıların, çıplak duvarda nabzl,

Çivi yaralarında, çivi yaralarında. (s.161) 


\subsection{Bilinçaltı ve İmge}

İmge, varlıkların insanın iç dünyasındaki farklı algılanış biçimi olup şairin bilinç ve bilinçaltı taraflarıyla da ilgili bir kavramdır. Her şairin kendine özgü imge dünyası olabilir. Necip Fazıl'ın şiir dünyasında imgenin de önemi vardır. 0, madde-ruh tezadında kişinin trajedisini yer yer imgesel boyutta dile getirir.

"Çile" adlı şiirin ilk dörtlügünde bireyin bilinçlenme süreci dile getirilir. "Bilinçlenme sürecine giren ben-anlatıcının sırtına büyük bir yük verilmiștir." (Karabulut, 2019: 325). Burada kişinin olgunlaşma sürecine girdiği görülür. Şair, "gök devrildi" derken gök kelimesini imgesel manada bilinçlenme sürecinin bir objesi olarak kullanır:

Gâiblerden bir ses geldi: Bu adam,

Gezdirsin boşluğu ense kökünde!

Ve uçtu tepemden birdenbire dam;

Gök devrildi, künde üstüne künde... (s.16)

Şiirde "lügat" ve "ayna" imgeleri kişinin kimlik arayışı veya benlik sorunsalı ifade edilir:

Lûgat, bir isim ver bana halimden;

Herkesin bildiği dilden bir isim!

Eski esvablarım, tutun elimden;

Aynalar, söyleyin bana, ben kimim? (s.19)

Kısakürek, "Kaldırımlar-I" adlı şiirde "kaldırım"ı imgesel anlamda kullanır. "Kaldırım" imgesi, "anne, insan, lisan" bağlamlarında ele alınır:

Kaldırımlar, çilekeş yalnızların annesi;

Kaldırımlar, içimde yaşamış bir insandır.

Kaldırımlar, duyulur, ses kesilince sesi;

Kaldırımlar, içimde kıvrılan bir lisandır. (s.157)

"Otel Odaları" adlı şiirde "otel” sözcüğü, "atılmışlık, yalnızlık ve yabancılık” bağlamlarında olumsuz bir mekân olarak tasvir edilmiştir:

Bir merhamettir yanan, daracık odaların,

İsli lâmbalarında, isli lâmbalarında. (s.157)

2.4. Benlik/Kimlik Çoğullanması

Benlik, psikolojik manada insanın kişiliğinin temelinde olan duygu ve düşüncelerin bütünüdür. Kişi, ideal benliğe ulaşmak için çoğu zaman iç ve dış çatışmalar yaşar. Necip Fazll'ın bazı şiirlerinde kimlik arayışının bir parçası olarak benlik çatışması da görülür. Bu çatışma benlik çoğullanması olarak da kendini gösterir. Onun "Ben" adlı şiirinde bireyin ben'iyle dış dünyadaki nesneler arasında bağlar kurulur:

Ben, kimsesiz seyyahı, meçhuller caddesinin...

Ben, yankısından kaçan çocuk kendi sesinin...

Ben, sırtında taşıyan işlenmedik günahı. (s.67)

Şiirde ben-anlatıcı kaotik bir yapı gösterir. "Şiirde "ben" tezatlar içerisinde, ontolojik ve psikolojik bir yapı arz eder. Öyleki ben-anlatıcı kendisini işlenmemiş günahın bile sorumlusu tutmaktadır." (Karabulut, 2019: 329).

Ben-anlatıcı benlik parçalanması içerisinde olup trajik bir yapı gösterir. Şairin benlik/kimlik oluşturma sorunsalı şairin bilinçaltındaki çıkmazlarla beraber bilinçdışına yansıtılır. Şiirin sonraki kısımlarında "şairin beni", "yolcu inmeyen hanların usanmaz bekçisi, buz tutmuş kayalarda kutup yelkenlisi, ısınmaz külhanların tükenmez ormanı, boşlukta düşen fikir, benliğin dolabında kör ve çilekeş beygir"dir. İmgesel boyutta benlik/kimlik oluşturma sorunsalı şairin bilinçaltındaki çıkmazlarla beraber bilinçdışına yansıtılır. (Karabulut, 2015: 609).

Ben, usanmaz bekçisi, yolcu inmez hanların; 
Ben tükenmez ormanı, ısınmaz külhanların...

Ben, kutup yelkenlisi, buz tutmuş kayalarda;

Öksüzün altın bahtı, yıldızdan mahyalarda...

Ben, başı ağır gelmiş, boşlukta düşen fikir;

Benliğin dolabında, kör ve çilekeş beygir... (s.67)

"Ben" başlıklı şiirde kişinin kimlik arayıșı ve benlik çatışmaları ön plandadır. "Ben" şiirinin sonunda şairin tezatları ve benlik parçalanması üst düzeye ulaşır. Bu durum adeta kişi için bir kıyameti andırır. "İnsan ruhunun bütünlügünü temsil eden 'benlik', rüyalarda görülen imgelerin kaynağı, zıtlıkların bileşimidir; hem egoyu hem de egonun diğer unsurlarını oluşturur." (Cebeci, 2007: 226).

\section{Sonuç}

Psikanaliz, Sigmund Freud'un temellerini attığı psikolojik kuramlar bütünü olup bireyin ruh dünyası üzerinde çözümlemeler ve tedaviler uygular. Sanatçının diğer insanlardan farklı bir algı ve ifade yönünün olduğunu dile getiren Freud, Sanat ve Sanatçılar adlı eserinde bu hususu irdeler. Türk şiirinin usta kalemlerinden Necip Fazıl Kısakürek'in şiirleri psikanalitik bağlamda irdelenmeye değerdir. Kısakürek'in şiirlerinde psikanalitik bağlamda "bilinçaltı, yeniden doğuş, boşluk duygusu, benlik kamaşası, var oluş mücadelesi vb.” izleklerle açığa çıkar. Kısakürek'in arayış yolculuğunda ve varoluşunu gerçekleștirme çabaları bazı şiirlerinde bir "yeniden doğuş" izleği ortaya çıkarır. Özellikle "Çile", "Tam Otuz Yıl” ve "Muhasebe" adlı şiirlerinde bunu daha belirgin görmek mümkündür. Şairin "Ben" şiiri başta olmak üzere bazı şiirlerinde "benlik çatışması" veya "benlik çoğullanması" ile karşılaşırız. Onun şiirlerinde yer alan bilinçaltı ve bilinçdışı unsurlar da psikanalitik edebiyat kuramı çerçevesinde irdelenebilecek hususlar arasındadır.

\section{KAYNAKÇA}

CEBECi, Oğuz (2009), Psikanalitik Edebiyat Kuramı, İthaki Yayınları, İstanbul.

EAGLATON, Terry (2001), Edebiyat Kuramı, çev. Tuncay Birkan, Ayrıntı Yayınları, İstanbul.

EMRE, İsmet (2006), Edebiyat ve Psikoloji, Anı Yayıncılık, Ankara.

EROL, Kemal (2014), "Bir Dava ve Toplum Adamı Olarak Necip Fazıl'ın Fikir Çilesi”, International Journal of Languages' Education and Teaching (IJLET), Volume $3 / 2014$.

FREUD, Sigmund (1998), Psikanaliz Üzerine, (Çev. Kamuran Şipal), Cem Yayınları, İstanbul.

FREUD, Sigmund (2012), Sanat ve Sanatçılar Üzerine, Çeviren: Kâmuran Şipal, : Yapı Kredi Yayınları, İstanbul.

FROMM, Erich (1991), Psikanaliz ve Din, (Çev. A. Arıtan), Arıtan Yayınevi, İstanbul.

GARIPER, Cafer (2014), "Necip Fazıl'da ve Ahmet Hâşim'de Başın Aykırılığı ve Horlanışı”, bilig, Kış 2014 / SAYI 68.

GÜNGÖR, Bilgin (2015), “Necip Fazıl Kısakürek'in 'Muhasebe' Adlı Şiirinde Yeniden Doğuş Arketipi”, Uluslararası Sosyal Bilimler Dergisi, Cilt: 8, Sayı: 37, Nisan 2015.

HÜKÜM, Muhammet (2013), “Necip Fazıl'ın 'Çile' Şiirinde 'Yüce' ve ‘Trajik' Üzerine Bir Tahlil Denemesi”, Asia Minor Studies, International Journal of Social Science, Cilt:1 Sayı:1 Ocak 2013/ Volume: 1 Issue: 1 January.

JUNG, Carl Gustav (2013), Dört Arketip, (Çev.: Zehra Aksu Yılmazer), Metis Yayınları, İstanbul.

KARABULUT, Mustafa (2011), “Cahit Sitkı Tarancı'nın Şiirlerine Psikanalitik Bir Yaklaşım”, Turkish Studies International Periodical For the Languages, Literature and History of Turkish or Turkic, Volume 6/3 Summer 2011. 
KARABULUT, Mustafa (2012), "Şairin Dil ve Üslûbunda Psikolojik Temayüller", 2. Uluslararası Türk Dili ve Edebiyatı Sempozyumu (Dil ve Üslûp İncelemeleri), 19-21 Ekim 2011, Isparta.

KARABULUT, Mustafa (2015), “İmge Kavramı ve Necip Fazıl Kısakürek'in Şiirlerinde İmge”, Turkish Studies - International Periodical For The Languages, Literature and History of Turkish or Turkic Volume 10/4 Winter 2015.

KARABULUT, Mustafa (2019a), "Psikanalitik Edebiyat Kuramı Bağlamında Edip Cansever'in Şiirleri Üzerine Bir İnceleme”, Edebî Eleştiri Dergisi, Eleştiri Kuramları Özel Sayısı, c. 3/3, s. 192-220.

KARABULUT, Mustafa (2019b), Üslûpbilim (Stilistik) ve Necip Fazıl Kısakürek'in Şiirleri Üzerinde Stilistik Bir İnceleme, Akçă̆ Yayınları, Ankara.

KISAKÜREK, Necip Fazıl (1995), Çile, Büyük Doğu Yayınları, İstanbul.

KOLCU, Ali İhsan (2008). Edebiyat Kuramları Tanım-Tenkit-Tahlil, Salkımsöğüt Yayınevi, Ankara.

KORUCU, Arzu (2019), "Ruh Adam'da Animayla Aydınlanan Yeniden Doğuş Arketipi: Selim Pusat'ın Sonsuz Istırabı”, Manas Sosyal Araştırmalar Dergisi, 8 (Ek Sayı 1) 710-724.

SAĞLAM, M. Halil (2014), "Necip Fazıl Kısakürek'in Otel Odaları Şiirini Psikanalitik Edebiyat Kuramı Bağlamında Okuma Denemesi”, Uluslararası Sosyal Araştırmalar Dergisi, Cilt: 7, Sayı: 33.

SONTAG, Susan (1991), Sanatçı: Örnek Bir Çilekeş, Metis Yayınları, İstanbul.

TAŞDELEN, Vefa (2005), “Necip Fazıl'ın Çilesi, Şiiri ve Poetikası Arasındaki İlişki Üzerine”, HeceAylık Edebiyat Dergisi (Düşünce, Tarih ve Bir Coğrafya Tasarımı Olarak Büyük Doğu ve Necip Fazıl Kısakürek Özel Sayısı), Sayı: 97, Ocak 2005.

TÜRKÇAPAR, Hakan (2004), “Anksiyete Bozukluğu ve Depresyonun Tanısal İlişkileri”, Klinik Psikiyatri 2004; Ek 4:12-16.

YILMAZ, Enser (2014), “Türk Şiirinde 'Otel’ İmgesi: Karşılaştırmalı Bir Çalışma”, Akademik Sosyal Araştırmalar Dergisi, Yıl: 2, Sayı: 7, Aralık.

YUVA, Hümeyra (2009), "Türk Şiirinde Zaman Teminin Değişimi”, International Periodical For the Languages, Literature and History of Turkish or Turkic, Volume 4 /1-II Winter. 
TWO AUTHORS IN THE CONTEXT OF SOCIALIST-REALISTIC LITERATURE: JOHN STEINBECK AND ORHAN KEMAL

Hasan YURTBEKLER 


\title{
TWO AUTHORS IN THE CONTEXT OF SOCIALIST-REALISTIC LITERATURE: JOHN STEINBECK AND ORHAN KEMAL
}

\author{
Hasan YURTBEKLER ${ }^{1}$
}

\begin{abstract}
:
Increasing mechanization since the Industrial Revolution has affected many societies of the world, especially Western societies. Increasing mechanization with the revolution has brought with it migration movements due to economic origin. Increasing migration from rural areas to cities with the dream of a better life has resulted in worse socio-economic results rather than individuals leading a better life. The surplus of workers resulting from the ever-increasing population in the cities has provided the capital owners with the opportunity to employ workers at a lower cost. As a result, working hours increased and wages decreased. Workers are compelled to lead an inhuman life in the cities. Increasing mechanization has begun to show its effect in rural areas as well, with the mechanization in agriculture, the workforce of the villagers has decreased, and their lands have been taken away from them by means of banks and they have been forced to migrate. Some artists could not remain indifferent to these difficult life conditions experienced by the workers, and they dealt with this subject in their works. This situation brought with it a new understanding of literature. This understanding is the "Socialist Realist" understanding of art, the foundation of which was laid in Soviet Russia in 1934. With this understanding, a number of duties and ideologies have been imposed on the artist and the artist. In this study, in addition to the universality and literary similarity of the subjects of John Steinbeck and Orhan Kemal, two writers from different geographies in the context of SocialistRealistic Literature understanding, the social and political reasons why Orhan Kemal could not achieve such a great reputation as Steinbeck despite this literary success are both sociological and sociological. and will be examined from the perspective of comparative literature.
\end{abstract}

Key words: Socialist Literature, Orhan Kemal, John Steinbeck.

http://dx.doi.org/10.47832/Lan.con3-6

${ }^{1}$ Yakın Doğu University, Türkiye, hasanyurdbekler@hotmail.com, https://orcid.org/0000-0002-5110-9853 


\section{TOPLUMCU-GERÇEKÇİ EDEBIYAT BAĞLAMINDA İKİ YAZAR: JOHN STEİNBECK VE ORHAN}

\section{Öz:}

Sanayi Devrimi'nden itibaren artan makineleşme başlangıçta Batı Toplumları olmak üzere dünyanın birçok toplumunu etkilemiştir. Devrim ile birlikte artan makineleşme, ekonomik kaynaklı olarak göç hareketlerini de beraberinde getirmiştir. Daha iyi bir yaşam hayaliyle kırsal alanlardan kentlere doğu artan göçler bireylerin daha iyi bir yaşam sürmesinden ziyade sosyoekonomik açıdan daha kötü sonuçlar doğurmuştur. Kentlerde sürekli artan nüfustan kaynaklanan işçi fazlalığı sermaye sahiplerine daha ucuza işçi çalıştırma olanağı sunmuştur. Buna bağlı olarak çalışma saatleri artmış ve ücretler düşmüştür. İşçiler kentlerde insanlık dışı bir yaşam sürmeğe mecbur bırakılmıştır. Artan makineleşme kırsal alanlarda da etkisini göstermeye başlamış, tarımda makineleşme ile birlikte köylülerin iş gücü azalmış, bankalar aracılığıyla da toprakları ellerinden alınarak göçe zorlanmışlardır. İşçilerin yaşadığı bu zorlu hayat şartlarına bazı sanatçılar kayıtsız kalamamış eserlerinde bu konuyu işlemişlerdir. Bu durum beraberinde yeni bir edebiyat anlayışını getirmiştir. Bu anlayış 1934 yılında Sovyet Rusya'da temeli atılan 'Toplumcu Gerçekçi' sanat anlayışıdır. Bu anlayışla birlikte sanatçı ve sanatçıya bir takım görev ve ideolojiler yüklenmiştir. Bu çalışmada Toplumcu -gerçekçi Edebiyat anlayışı bağlamında farklı coğrafyaların iki yazarı olan John Steinbeck ve Orhan Kemal'in işledikleri konuların evrenselleği ve edebi benzerliğinin yanı sıra, bu edebi başarıya rağmen Orhan Kemal'in, Steinbeck kadar büyük bir üne kavuşamamasının toplumsal ve politik nedenleri hem sosyolojik ve karşılaştırmalı edebiyat perspektifinden bakılarak irdelenecektir.

Anahtar Kelimeler: Toplumcu Edebiyat, Orhan Kemal, John Steinbeck.

\section{Giriş}

Marx ve Engels'in temelini oluşturdukları Marksiszm başta toplum ve ekonomi olmak üzere birçok konuda maddeci perspektiften hareket eden ve her türlü toplumsal konuyu bu pencereden değerlendiren sosyal bir teoridir. Marksizm bu konuların yanı sıra kendine has bir edebiyat anlayışı da geliştirmiştir. Bu edebiyat anlayışı 1934 yılına kadar birçok yazar ve teorisyenin görüşleri çerçevesinde şekillenmiştir. 1934'te toplanan Birinci Sovyet Yazarlar Birliği Kongresi'nde alınan kararlar doğrultusunda 'Toplumcu-Gerçekçilik' bir sanat anlayışı olarak oluşturulup kabul edilmiştir. Bu anlayış sanata ve sanatçıya ideolojik açıdan bir takım görevler yüklemektedir. İşçi sınıfının ezilmesine karşı olan ve bu sınıfın öncülüğünde yapılacak bir devrimi savunan yazarlar, eserlerinde de genellikle bu sınıfı konu alır. Bu nedenle, yoksulluk, ağır çalışma koşulları, hastalık, işçilerin uğradığı haksızlıklar, köylülerin yorucu günlük yaşantıları gibi konular, Toplumcu Gerçekçi Edebiyat akımının en sık değindiği temalar arasında yer almaktadır. Bu akım toplumcu dünya görüşü üzerine temellendirilmiş bir edebiyat akımıdır. Sosyal sınıflar arasındaki çatışmaları ortaya koyan ve bu sorunların çözümü için fikirler üreten bir görüşe sahiptir. Bu bağlamda toplumcu gerçekçilik akımı toplum için ilkesine bağlı olarak edebiyata eğitici bir misyon yükler.

Özetle 'Toplumcu Gerçekçilik Akımı', toplum için sanat anlayışının bir alt öğesi olarak görülebilir. Bu sanat anlayışını benimseyen yazarlar, sanatın toplum açısından işlevsel olması gerektiğini düşünürler ve eserlerinde bireyleri belli konularda bilgilendirmeyi, inandıkları değerler doğrultusunda mesajlar vermeyi, yeri geldiğinde de bireyleri bu konularda harekete geçirmeyi amaçlar. 
Adından da anlaşılacağı gibi, bu romanlar "gerçekçi" romanlardır. Ele aldıkları konuları olduğu gibi aktarmaya, gerçek hayatta yaşanabilecek olaylardan bahsetmeye, mistik ve abartılı mesajlardan kaçınmaya çalışmaktadırlar.

Toplum için sanat" ve "gerçekçilik" anlayışlarının bir birleşimi olmasının ötesinde, Toplumcu Gerçekçiliği kendi içinde önemli bir edebi akım haline getiren şey, bunun genellikle Marksist yazarlar tarafından tercih edilmesidir. "Toplumcu Gerçekçi olan her yazar Marksist'tir" diye bir genelleme yapmak doğru olmamakla beraber bu akımla ilgilenen yazarların çoğu Marksist görüşlüdür.

Ele aldığı konulara paralel olarak Toplumcu gerçekçi edebiyat akımı toplumdaki çarpıklığı, kültür çatışmalarını, işçilerin yaşadığı zor hayat şartlarını ele aldığından dolayı bu çarpıklığı ele alırken bunların en büyük nedenlerinden bir tanesi olan 'göç' olgusuna kayıtsız kalmayacağı pek tabiidir.

\section{Göç Olgusu}

İnsanların kavram ve nesneleri adlandırmalarının altında yatan pek çok neden bulunmaktadır. Politik sebepler, doğa olayları, coğrafi şartlar, geçim kaynakları, uğraşılan meslekler akla ilk gelen nedenlerdir (Tuğluk, 2021: 154-155). Geçmişten bugüne kadar hayatın her aşamasında bir olgu olarak görülen göçün birçok farklı nedeni bulunmaktadır. Göç hareketleri tarihin akışını ve insanlığın seyrini derinden etkilemiştir.

Dönem dönem farklı nedenlerden dolayı yavaşlayan veya hızlanan göçler, gerçekleşme nedenine bağlı olarak farklılık göstermektedir. Geçmişten bugüne kadar bakıldığında göç hareketlerinde ekonomik nedenlerin daha önde olduğu söylenebilir. 19. yüzyıldaki sanayileşme hareketleri ile birlikte kırsal alanlardan kentlere yapılan göçler, hep kentlerin genişlemesine yol açmıştır. Bu dönemdeki göçlerin özelliklerinden biri kitleler halinde yapılmasıdır.

İşçiler fabrikalarda çalıştırılmaya başlamalarından itibaren nitelikli işçi haline dönüştürülmektedir. Kentlere doğru yoğunlaşan göçler, fabrikaların ihtiyacı olan iş gücünü aşmaya başlar. Bu durum fabrikaların daha fazla işçi çalıştıramamasına ve işçilerin alacakları ücretin düşmesine sebep olur. Kentler nüfus yoğunluğunun ekonomik açıdan gereksinimlerine karşılık verememeye başladığında kırsal alanlarda sanayileşme hareketleri meydana gelmeye başlar. Uğurlu (2010) göre:

"Çalışmak için kente gelen nüfusun barınma ihtiyacını karşılayacak alanlar yetersiz kalınca kent dışında yeni yerleșme alanları işçi mahalleleri oluşmuştur. Fabrikaların hemen yanında inşa edilen işsiz konutları yan yana ve kötü malzeme ile yapılmıştır. Konut sunum mekanizmaları artan isteği karşılayamayınca konut birimleri bölünerek kiralanmaya (her aileye bir oda) başlamış, bu da aşırı yoğunlukla birlikte sağlıksız yaşam koşullarını beraberinde getirmiştir"

Bu alanlarda kurulan yeni fabrikalar nüfusu çekmeye başlar ve yeni yeni kentlerin ortaya çımasına olanak sağlar. Kısaca denilebilir ki sanayileșme hareketleri ile birlikte kırsal alanlar kentleşmeye doğru bir evirilme içine girer. Bu evirilme aynı zamandan altyapısı olmayan çarpık bir yerleşim düzenini beraberinde getirir. Bu kentlerde işçi sınıfı büyük çoğunluğu oluşturur.

$\mathrm{Bu}$ andan itibaren işçilerin ayakta kalmak için vereceği mücadelenin izlerini taşımaktadır. Toplumsal savaş herkesin herkese karşı vereceği bir savaştır. Güçlü güçsüzü ayağının altına alarak ezmeye çalışırken işçi sınıfının sosyal. Kültürel, ekonomik vb. alanlarda verdiği mücadele bugün bile devam etmektedir. Çünkü kapitalist güçler her şeye kendi çıkarları için el koymakta, işçiler için geriye çok az şey kalmaktadır. Kapitalizmin etkisi altındaki kentlerde bencillik, kayıtsızlık ve toplumsal bir savaş hüküm sürmektedir. $\mathrm{Bu}$ durumun oluşturduğu bütün 
olumsuzluklar işçilerin sırtına binmektedir. İşçiler kimsenin umurunda olmamakla birlikte bir çıkmazın içine itilmişlerdir. Hayatta kalmak için ellerinden geldiğince çabalamakta bunun sonucu olarak iş bulmuşsa ve sermaye sahipleri bu işçilerin sırtından rant sağlama lütfunu onlara bağışlamışsa ne ala. Aksi takdirde aç kalmamak uğruna toplumsal huzuru, bu huzurdan kasıt aslında burjuvanın huzuru olsa da, bunu bozacak işlere kalkışacaklardır. İşledikleri suçun gerçek nedeni hiçbir zaman onları haklı çıkarmayacaktır. Çünkü gerçek suçlu aslında onlara bunu yaptıran sitemdir. Engels'e göre:

"Sermaye, geçim ve üretim araçlarının doğrudan ve dolaylı denetimi - bu toplumsal savaşımın yürütüldüğü silah olduğuna göre, böyle bir durumun bütün dezavantajlarının yoksulun sırtına bineceği apaçıktır. 0 , kimsenin umurunda değil. Girdabın içine itilmiş, elinden geldiğince çabalıyor. İş bulma mutluluğuna erişmişse, yani burjuvazi onun sırtından zengin olma lütfunu ona bahşetmişse, kendisini bekleyen ücret, ruhuyla bedenini bir arada tutmasına ucu ucuna yetecek bir ücret" (Engels, 1997: 54-55)

Temelde sosyolojik bir olgu olarak değerlendirilen göç olgusu daha sonraki dönemlerde yapılan çalışmalar neticesinde farklı disiplinlerin de dikkatini çekmiştir. Toplumcu-Gerçekçi edebiyatın ortaya çıkışı ve yaygınlaşmasından itibaren kırsal kesimlerden kentlere olan göç, sosyal, kültürel ve ekonomik bir sorunsal olarak roman karakterleri ile birlikte merkeze alınmış ve konuya bu açıdan yaklaşılmıştır.

Göç olgusunu temelinde bireylerin yaşamış olduğu zorlu hayat şartlarını romanlarında çok çarpıcı bir șekilde işleyen yazarlardan iki tanesi John Steinbeck ve Orhan Kemal'dir.

Toplumcu-gerçekçi edebiyatın bu iki önemli temsilcisinin Romanları birçok yönden birbirlerine benzerlik göstermektedir. Bunda toplumsal meselelerin evrenselliğinin payı büyüktür. Romanlarında genelde göçe dayalı bireylerin yaşadığı sosyal kültürel ve ekonomik sorunlar irdelenmiş ve okuyucuda derin izler bırakmışlardır.

Farklı coğrafyaların insanı olmalarına rağmen benzer eserler otaya koyan bu iki yazar, aynı șekilde farklı coğrafyalardan olmalarının bir sonucu olarak farklı şöhretlere sahip olmuştur. Steinbeck kadar değerli eserler ortaya koymasına rağmen Orhan Kemal dünya çapında hak ettiği üne kavuşamamıştır. Bunda döneminin baskıcı siyasi anlayışın payı büyüktür. Steinbeck ortaya koyduğu eserlerden dolayı takdir edilip ödüller alırken; Orhan Kemal, görüşlerinden ve okuduğu yasaklı kitaplardan dolayı hapis cezası almış, işsiz kalmış hayatı geçim sıkıntısı ile mücadele ederek geçmiştir. Bu iki yazarın hayatı ve ortaya koyduğu eserler ve fikirleri şu şekilde ortaya koyulabilir.

\section{JOHN STEİNBECK VE EDEBİ KİŞİLİĞİ}

27 Şubat 1902'de doğan john Steinbeck Amerikan Toplumcu -gerçekçi edebiyatının en önde gelen yazarlarından birisidir. İrlanda asıllı olan yazar romanlarında genellikle işçilerin yaşamını ve toplumsal sorunları dile getirmiştir. Gençlik dönemlerinde işçilik yaptığı Salinas Vadisi onun eserleri için vazgeçilmez bir mekândır. Amerika'daki büyük buhran dönemini yaşamış ve sosyo-ekonomik etkisini iliklerine kadar hissetmiş olan yazarın ortaya koyduğu eserlerinde bunun izlerine sık sık rastlamak mümkündür. Yazdığı eserlerin her biri kült olmuş çoğu da sinemaya uyarlanmıştır.

Tarımda makineleşmenin ve bankaların topraklarına el koyarak zorla göçe zorladıkları köylülerin dramını konu alan "Gazap Üzümleri” adlı romanında bir ailenin Oklahoma'dan Kaliforniya' göç ettiği sırada yaşadığı olaylar çok çarpıcı bir anlatılmış ve kapitalizmin vahşeti 
bütün çıplakllğıyla gözler önüne serilmiştir. Bu roman Pulitzer ve Ulusal Kitap Ödülü'nü kazanmıştır. Bu eser sayesinde Steinbeck, uluslararası bir üne kavuşmuş ve daha sonra yazacağı romanlar için ilham kaynağı olmuştur.

\section{ORHAN KEMAL VE EDEBİ KIŞ̧iLí̆Ğ}

Gerçek adı Mehmet Raşit Öğütçü olan Orhan Kemal, 15 Eylül 1914'te Adana Ceyhan'da doğmuştur. Türkiye'de yoksul kesimin yaşantısını anlatan Toplumcu-gerçekçi bir yazardır. Gençlik yıllarında Adana'nın pamuk fabrikalarında dokumacılık ve kâtiplik yapmıştır. Yaşadığı yoksul hayatın etkileri romanlarında ağırlı̆̆ını hissettirmiştir.

1938'de askerliğini yaparken siyasi görüşlerinden dolayı 5 yıl hapis cezasına çarpıtılmıştır. Bu cezayı almasının nedenleri arasında Maksim Gorki ve Nazım Hikmet'in eserlerini okuması da vardır. Bursa cezaevinde Nazım Hikmet ile tanışmıștır. Ve bu tanışma Orhan Kemal'in romancılığa başlamasına vesile olmuştur. Orhan Kemal o zamana kadar şiirler yazmakta idi. Nazım Hikmet'in teşvikiyle hikâye ve roman yazmaya başlamıştır. Aynı zamanda Nazım'ın dünya görüşünden etkilenmiş bu durum edebi kişiliğine yön vermiştir. 1966 da Komûnist propagandası yapmak suçundan tekrar tutuklanmış 2 ay sonra delil yetersizliğinden serbest bırakılmıştır. Orhan Kemal dünya görüşlerinden dolayı sürekli olarak engellemelerle karşılaşmış baskı ve cezalar yemiştir. Bu durum onun sanatını icra etmesini çoğu zaman sekteye uğratmıştır. John Steinbeck ile kıyaslandığında romancılı̆̆ ve üslubu açısından Steinbeck kadar usta olmasına rağmen, onun kadar uluslararası bir üne kavuşamamasını nedenleri arasında uğradığı politik baskı ve yıldırmaların büyük etkisinin olduğu düşünülebilir. İki yazar arasında benzer ve farklı özelliklere bakılarak bu durum daha net bir şekilde anlaşılacaktır.

\section{İKİ YAZAR ARASINDAKİ BENZERLİKLER}

Öncelikle John Steinbeck'in özelliklerine baktığımızda; Dünya edebiyatında, Toplumcugerçekçilik akımının en büyük temsilcilerinden biri olduğu su götürmez bir gerçektir. Orhan Kemal ise neredeyse bütün eserlerinde sosyalist, toplumcu gerçekçi bir yazar olmuştur. İkisinin de romanları yaşadıkları döneme gerçekçi bir tanıklık yapıyor. Tıpkı Steinbeck gibi Orhan Kemal' de dönemin toplumundaki değişimi romancıdan daha çok bir sosyolog, bir bilim insanı gibi ele almaktadır. İkisi de romanlarında özellikle tarım işçilerinin yaşadığı zorlu hayatı kapitalizmin yıkıcı etkilerini, ekonomik buhranların getirdiği sosyal bozgunları çok adeta olayları yaşayarak o işçilerden biri olarak betimlemişlerdir. Sanat kaygısından uzak estetiği arka plana atan ve sanatçının asıl görevinin topluma karşı sorumlu olduğu düşüncesi ile yazmışlardır. İkisinin de anata dair bir kaygısı yoktur. Tek düşünceleri toplumdaki sorunları ortaya koymak, çözüm sunmak ve okuyucuyu düşündürmektir. Steinbeck, Life dergisi için 1938 yllında meyve işçileri ile ilgili yazılar yazdığında, yalnızca masraflarını almıştır. Dergiyle, yazıdan gelecek kazancın işçiler için kurulmuş yardım sandığına verilmesi için anlaşıp, "Bu insanların sırtından para kazanmamak için” başka dergilerin yazı önerilerini geri çevirmiştir. Orhan Kemal ise "Bereketli Topraklar Üzerinde" adlı eserinde, köyden kente ekonomik sıkıntılardan dolayı köylerini terk edip kente gelen üç arkadaşın yaşadığı sosyal değişimleri o yerin şivesini romanlarında konuşturacak kadar eserle iç içedir. Steinbeck, Gazap Üzümleri'nde California'nın meyve bahçelerinde ölümüne çalışan emekçilerin işleyip kazandığı ürünlerin nasıl bir-iki kişinin elinden geçtiğinin öyküsünü, hatta uzun yol şoförlerinin, hikâyesini anlatırken, Orhan Kemal Çukurova'nın tarım işçilerinden, köyden kente göç eden işçilerin fabrikalarda, madenlerde yaşanan vahşi, gaddar sömürüye kadar insanların geçim sıkıntısından bahsetmiştir. 


\section{İKİ YAZAR ARASINDAKİ FARKLILIKLAR}

Steinbeck'in Gazap Üzümleri adlı eserinde gerçekleşen olaylar dini kıssadan hisseler gibiydi. Ekmek ya da şeker almaya parası yetmeyen işçinin yerine ona şeker alan çiftlik kasiyeri, gezici işçilerin alışverişinden artan azıcık paraya çocuk sayısınca pahalı şeker alan kadınlar vb. Fakat Orhan Kemal'in "Bereketli Topraklar Üzerinde" adlı esrinde olaylar bir bakıma kurgusal, şayet oldukça realistik bir çizgide gerçekleşmektedir. İdeal toplum algısını yaratmak için dini ve vicdani duygulara yönelmez. Romanda bir işçi ayağını batöz makinesine kaptırır ve çok kan kaybetmektedir. Patronu arabası kirlenmesin diye arabasına almaz. İşçi kan kaybından ölür.

John Steinbeck ve Orhan Kemalin ayrıldıkları en büyük nokta ise politikadır. Daha doğrusu politikanın kendilerini ele geçirmelerine ne derece izin verdikleridir. Romancılığının en parlak yıllarında işçi sınıfının yanında olup onlar için savaşmış olan Steinbeck her ne kadar eşitlikçi olsa da bireyciliğinin etkisinden işçi sınıfının ideolojisine olan bağlılığını devam ettirememiş hatta zamanla ondan nefret eder hale gelmiştir. Geçmiş zamanlarında, Gazap Üzümleri'ni yeni çıkartacağı dönemde eserinin adını, bir Amerikan marşından almasını istediğinde baş gösteren ırkçlık sonraki yaşamında giderek artmış. Hatta o dönemde bile eserine "Cumhuriyet Savaş Şarkısı" adını vermek istemesinin sebebi eserin komünizme dair unsurlar bulunduruyor olması ve bunun başına bela olmasını istememesinden olduğu tahmin edilmektedir. Sonunda ismi İncil'den bir tasvir olan "Gazap Üzümleri” ile değiştirmiştir.

Steinbeck. 1950'lerden sonra bambaşka bir siyasi görüşle çıkmıştır.. Komünizm ve Sovyetler Birliği düşmanlığının yanı sıra Kore ve Vietnam işgallerini de şiddetle desteklemektedir. Bu olaylar sonrası hakkında yapılan şu yorum ruhsal halinin sebebini yeterince açıklamaktadır. "Gazap Üzümleri ona zorla toplumsal ve politik bir aktivist gömleği giydirmişti.” Bu gömlek ona ağır gelmiştir ve taşıyamamıștır. Oysaki Orhan Kemal hayatı boyunca karşılaştığı baskılara rağmen düşüncelerinden ve topluma olan sorumluluğundan taviz vermemiş yazdığı eserlerin arkasında durmuştur.

\section{SONUÇ}

Steinbeck'in savunduğu dünya görüşlerini ortaya koyduğu kült eserleri ileriki dönemlerde kaldıramayarak dönüş yapması gazeteci olarak gittiği Vietnam'da Amerika lehine savaşı haklı bulan ve kışkırtıcı yazılar yazması bir neyi geçmişte yazdığı eserlere işçi sınıfına ve kendi geçmiş hayatına karşı bir ihanet olup olmadığı tartışmaya açıktır. Steinbeck kazandığı Pulitzer ve Nobel Edebiyat ödüllerine rağmen ne yazık ki Orhan kemal gibi bir duruş sergileyememiştir. Orhan Kemal Steinbeck gibi uluslararası bir şöhrete kavuşamamıştır fakat hiçbir zaman için düşüncelerinden taviz vermemiş. Toplumun ezilen kesiminin yanında olmuştur. Sanatın topluma karşı sorumluluğunun bilincinde olmuştur. Orhan Kemal beli de politik baskı ve engellemelere, hapis cezalarına, yasaklamalara, geçim sıkıntısına uğramamış olsa idi belki de Steinbeck gibi uluslararası bir şöhrete sahip olabilirdi. Sanat toplum için vazgeçilmez bir unsurdur. Sanatsız bir toplum asla düşünülemez. Dolayısıyla sanatçıyı engellemek yerine onu desteklemek farklı düşüncelere saygılı olmak muasır medeniyetler seviyesine ulaşmak için çok önemli öğelerdendir. Temennimiz toplumun her kesimine hitap eden farklı görüşlere saygılı olan bir toplum ve siyasi anlayışın bu topraklarda hüküm sürmesidir. Bu vesile ile Orhan Kemal'i sevgi ve saygiyla anıyorum. 


\section{KAYNAKÇA}

Engels, F. (1997). Ingiltere'de Emekçi Sınıfının Durumu, Birinci basım, Ankara: Eriş Yayınları.

Kacıroğlu, M. (2016). Cumhuriyet Dönemi Türk Edebiyatında (1923-1940) Toplumcu-Gerçekçi Edebiyat Tartışmaları, ETÜ, Sosyal Bilimler Enstitüsü Dergisi, ss: 27-71

Kenter, B. (2020). Orhan Kemal'in Romanlarında Göç Merkezi Olarak Kentler ve Kültürel Araf, İstanbul Üniversitesi Dergisi. Cilt. 60, S1, ss. 331-346

Naci, F. (2012). Yüz Yılın 100 Türk Romanı, İstanbul: Türkiye İş Bankası Yayınları

Tuğluk, Mehmet Emin (2021). "İlyas Köyündeki (Diyarbakır-Çüngüş) Tarım ve Hayvancılık ile İlgili Söz Varlı̆̆ı" Uluslararası Dil, Edebiyat ve Kültür Araştırmaları Dergisi. (UDEKAD). 4 (1): 153-169

Uğurlu, Ö. (2010). Kentlerin Tarihsel Gelişimi, (Ed. Ö. Uğurlu, N.Ş. Pınarcıoğlu, A. Kanbak, M. Şiriner), Türkiye 



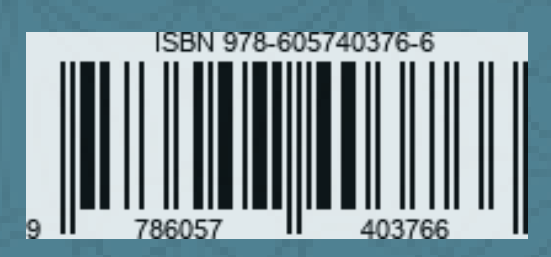

